\title{
MASTER
}

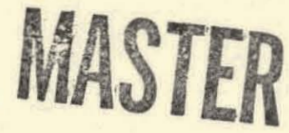

\section{Survey of Solar Thermal Energy Storage Subsystems for Thermal/Electric Applications}

\author{
C. L. Segaser
}




\section{DISCLAIMER}

This report was prepared as an account of work sponsored by an agency of the United States Government. Neither the United States Government nor any agency Thereof, nor any of their employees, makes any warranty, express or implied, or assumes any legal liability or responsibility for the accuracy, completeness, or usefulness of any information, apparatus, product, or process disclosed, or represents that its use would not infringe privately owned rights. Reference herein to any specific commercial product, process, or service by trade name, trademark, manufacturer, or otherwise does not necessarily constitute or imply its endorsement, recommendation, or favoring by the United States Government or any agency thereof. The views and opinions of authors expressed herein do not necessarily state or reflect those of the United States Government or any agency thereof. 


\section{DISCLAIMER}

Portions of this document may be illegible in electronic image products. Images are produced from the best available original document. 
Printed in the United States of America. Available from National Technical Information Service

U.S. Department of Commerce

5285 Port Royal Road, Springfield, Virginia 22161

Price: Printed Copy $\$ 6.50$; Microfiche $\$ 3.00$

This report was prepared as an account of work sponsored by an agency of the United States Government. Neither the United States Government nor any agency thereof, nor any of their employees, contractors, subcontractors, or their employees, makes any warranty, express or implied, nor assumes any legal liability or responsibility for any third party's use or the results of such use of any information, apparatus. product or process disclosed in this report, nor represents that its use by such third party would not infringe privately owned rights. 
Contract No. W-7405-eng-26

ENGINEERING TECHNOLOGY DIVISION

ENERGY DIVISION

SURVEY OF SOLAR THERMAL ENERGY STORAGE SUBSYSTEMS

FOR THERMAL/ELECTRIC APPLICATIONS

C. L. Segaser

Date Published: August 1978

OAK RIDGE NATIONAL LABORATORY

Oak Ridge, Tennessee 37830

operated by

UNION CARBIDE CORPORATION

for the

DEPARTMENT OF ENERGY 
THIS PAGE

WAS INTENTIONALLY

LEFT BLANK 
This study was carried out in 1976 for the Office of Technology Assessment (OTA) as a part of their response to the Congress of the United States on the viability of solar energy systems. The information contained in this report was included in abbreviated form as an appendix to the document transmitted by OTA to the Congress in about April 1977. It is felt that the full text of the ORNL statement would be sufficiently useful to warrant publication as an independent report.

July 1978 
THIS PAGE

\section{WAS INTENTIONALLY LEFT BLANK}


CONTENTS

FOREWORD . . . . . . . . . . . . . . . . . . . vii

ABSTRACT ......................... . . ix

1. INTRODUCTION . . . . . . . . . . . . . . . . 1

References for Section 1.............. 3

2. SOLAR ENERGY UTILIZATION IN RESIDENTIAL UNITS . . . . . . . 4

2.1 Single-Family Residence . . . . . . . . . . . . . . 4

2.2 Multifamily Housing . . . . . . . . . . . . . . 9

2.3 Reference City .. . . . . . . . . . . . . 15

References for Section 2................ . 21

3. SOLAR ENERGY CONVERSION SYSTEMS . . . . . . . . . . . . . 22

3.1 Space and Domestic Water Heating Systems . . . . . . . 22

3.2 Solar Space Cooling (Air Conditioning) Systems . . . . . 22

3.2.1 Solar Rankine Cooling . . . . . . . . . . 25

3.2.2 Solar Absorption Cooling . . . . . . . . . . 25

3.2.3 Combined Solar Heating and Cooling System . . . 27

3.3 Solar-Integrated Utility Systems . . . . . . . . . 27

3.3.1 The Solar Community Concept . . . . . . . . . 29

3.3.2 ORNL Conceptual Design Study for a Solar

Total Energy System ........... . . 30

3.4 Base-Load Power Generation Systems . . . . . . . . . . 36

References for Section 3... . . . . . . . . . . 40

4. CANDIDATE SOLAR THERMAL ENERGY STORAGE MATERIALS . . . . . . 42

4.1 Classification of Thermal Energy Storage Media . . . . . 42

4.1.1 Sensible Heat Storage Materials . . . . . . . 42

4.1.2 Latent Heat Phase-Change Materials . . . . . . 43

4.1.3 Clathrate and Semiclathrate Hydrates . . . . . 45

4.1.4 Metal Hydrides ............... 45

4.1.5 Inorganic Chemical Reactions . . . . . . . . 46

4.2 Characteristics of Candidate TES Media . . . . . . . 47

4.2.1 Low-Temperature TES Materials ....... . . 47

4.2.2 Intermediate-Temperature TES Media..... . . 50

4.2.3 Representative High-Temperature TES Media . . . 54

References for Section 4............... . 58

5. SELECTED CANDIDATE SOLAR ENERGY STORAGE SUBSYSTEMS . . • . . 60

5.1 Selection Criteria . . . . . . . . . . . . . . 60

5.2 Low-Temperature TES Subsystems . . . . . . . . . 61

5.3 Intermediate-Temperature TES Subsystems . . . . . . 63

5.4 High-Temperature TES Subsystems ... . . . . . . . 67

5.5. Thermal Energy Storage Efficiency .. . . . . . . . 70

References for Section 5................ 75 
6. SOLAR THERMAL ENERGY STORAGE COST CONSIDERATIONS . . • . . . . 77

6.1 TES Material Costs . . . . . . . . . . . . . . 77

6.2 TES Containment Unit Costs .. . . . . . . . . . 79

6.2.1 Latent Heat TES Unit Costs .......... . 79

6.2.2 Sensible Heat TES Unit Costs . . . . . . . . . 82

6.3 Estimated Costs of Solar Energy Storage Devices . . . . 83

6.4 Thermal Insulation Costs . . . . . . . . . . . 84

References for Section 6.............. 86 
FOREWORD

This report has been prepared to describe for the Congress of the United States the current technology and estimated costs of subsystems for storing thermal energy produced by solar collectors. The general format and contents of the report are in compliance with the recommendations of the Congressional office of Technology Assessment.

Several individuals and/or organizations in the United States are currently engaged in research pertaining to thermal energy storage (TES) materials and devices. The information presented herein is based on the results of such research available during the early months of 1976 .

The report is to be used to serve the following three functions: (1) it will serve as part of a draft of a paper giving an overview of solar technology; (2) it will be used to prepare preliminary designs for a variety of solar systems and to assist in the selection of several "base-line" designs, which will be subjected to detailed technical and economic analyses; and (3) it is to serve as a source document for the team that will perform the detailed analyses.

Each of the storage subsystems selected for study by ORNL are described in sufficient detail to provide (1) a layman's understanding of the physical principles governing the operation of the storage subsystem; (2) other technical personnel with information to integrate the storage unit into a solar system containing collectors, prime movers, heating and cooling units, etc.; and (3) a basis for reviewing the costs and operating characteristics associated with the storage technique. 
THIS PAGE

WAS INTENTIONALLY LEFT BLANK 


\section{ABSTRACT}

This report presents a survey of the current technology and estimated costs of subsystems for storing the thermal energy produced by solar collectors. The systems considered were capable of producing both electricity and space conditioning for three types of loads: a singlefamily detached residence, an apartment complex of 100 units, and a city of 30,000 residents, containing both single-family residences and apartments. Collector temperatures will be in four ranges: (1) 100 to $250^{\circ} \mathrm{F}$ (used for space heating and single-cycle air conditioners and organic Rankine low-temperature turbines); (2) 300 to $400^{\circ} \mathrm{F}$ (used for dual-cycle air conditioners and low-temperature turbines); (3) 400 to $600^{\circ} \mathrm{F}$ (using fluids from parabolic trough collectors to run Rankine turbines); (4) 800 to $1000^{\circ} \mathrm{F}$ (using fluids from heliostats to run closed-cycle gas turbines and steam Rankine turbines). The solar thermal energy subsystems will require from 60 to $36 \times 10^{5} \mathrm{kWhr}\left(2.05 \times 10^{5}\right.$ to $\left.1.23 \times 10^{10} \mathrm{Btu}\right)$ of thermal storage capacity.

Thermal energy in the form of either "hotness" or "coldness" can be stored in a variety of media as sensible heat by virtue of a change in temperature of the material or as latent heat of fusion in which the material changes from the liquid phase to the solid phase without an appreciable change in temperature. Both types of material have been used in thermal energy storage (TES) units.

In hotness storage, thermal energy is added to the TES medium, raising the temperature of sensible heat storage materials or melting the latent heat materials at constant temperature. In coldness storage, thermal energy is extracted from the medium, resulting in a decrease in temperature of sensible heat storage materials or constant-temperature freezing of latent heat materials. In both cases a temperature difference must exist between the thermal conveyance materfal and the TES medium to provide a driving force for heat transfer.

In addition to sensible heat and latent heat storage materials, several other media were investigated as potential thermal energy storage materials, including the clathrate and semiclathrate hydrates, various metal hydrides, and heat storage based on inorganic chemical reactions. 


\section{INTRODUCTION}

This report has been prepared to describe for the Congress of the United States the current technology and estimated costs of subsystems for storing thermal energy produced by solar collectors. The general format and contents of the report are in compliance with the recommendations of the Congressional Office of Technology Assessment (COTA).

One of the principal problems associated with application of solar electric conversion for residential consumption is the potential incompatibility that can exist between the available solar insolation and the thermal/electric demand for space heating and cooling, domestic hot water production, and electricity. This problem can be partially alleviated with a thermal energy storage (TES) subsystem that extends or defers the electrical generation capability and stores sufficient heat for use during periods of extended cloud cover and/or nighttime usage.

The amount of solar energy received on the earth's surface is estimated to be about 22,500 times the present worldwide energy usage of $1.8 \times 10^{17} \mathrm{Btu} /$ year. ${ }^{1}$ Because of the low intensity and intermittent nature of solar energy, the problem is to convert this energy to a useful form. Since solar energy at the earth's surface is not continuously available, practical systems for solar energy conversion require an energy storage device. The conversion and energy storage methods must be economically attractive as well as sufficiently efficient for their use to be initiated.

Representative nondimensional solar insolation data for clear days are shown in Fig. 1.1, assuming a winter optimized heliostat field. ${ }^{2}$ Effective solar insolation ceases at about 4:30 PM on winter solstice and extends to approximately 7:30 PM on summer solstice. By comparison, the peak winter electrical demand for typical residential units occurs between 6:00 PM and 12 midnight. Obviously, if electricity is to be produced around the clock from solar energy, the energy must be stored during hours when it is plentiful for subsequent use during the hours when electrical demand is high but solar insolation is minimal or nonexistent.

This report will discuss the costs and performance characteristics of devices for storing the thermal energy produced by solar collectors. The systems considered were capable of producing electricity and both electricity and space conditioning for three types of loads: a singlefamily detached residence, an apartment complex of 100 units, and a clty of. 30,000 residents, containing both single-family residences and apartments. Collector temperatures will be in four ranges: (1) 100 to $250^{\circ} \mathrm{F}$ (used for space heating and single-cycle air conditioners and organic Rankine low-temperature turbines); (2) 300 to $400^{\circ} \mathrm{F}$ (used for dual-cycle air conditioners and low-temperature turbines); (3) 400 to $600^{\circ} \mathrm{F}$ (using fluids' from parabolic trough collectors to run Rankine turbines); (4) 800 to $1000^{\circ} \mathrm{F}$ (using fluids from heliostats to run closed-cycle gas 
ORNL-DWG 77.19909

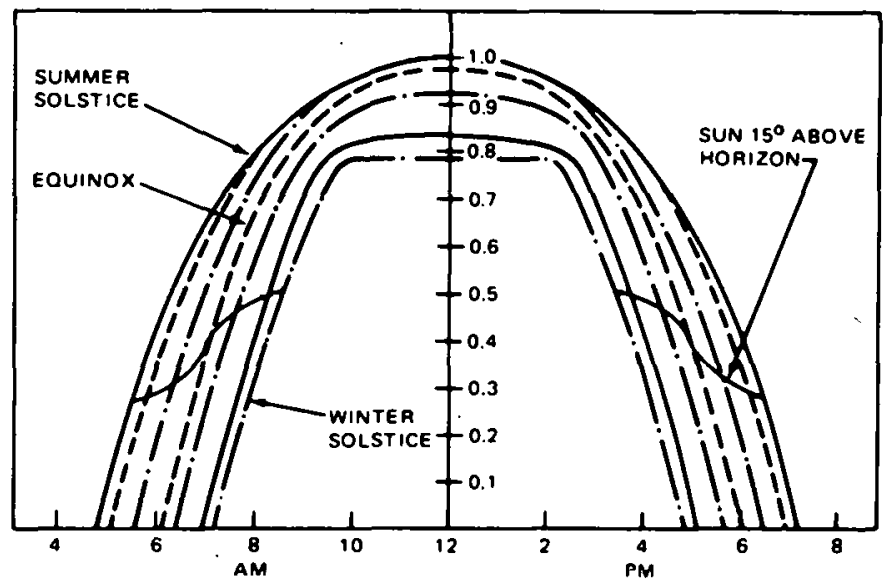

Fig. 1.1. Integrated nondimensional solar receiver heat flux. Source: By permission from J. E. Raetz, C. R. Easton, and R. J. Hall, "The Selection and Use of Energy Storage for Solar Thermal Electric Application," IECEC Paper 759088, in Record of the Tenth Intersociety thergy Conversion Engineering Conference, Institute of Electrical and Electronics Engineers, Inc., Hew York (August 1975), Fig. 2, p. 576.

turbines and steam Rankine turbines). The Office of Technology Assessment will be examining systems that will require from 60 to $36 \times 10^{5} \mathrm{kWhr}$ $\left(2.05 \times 10^{b}\right.$ to $1.23 \times 10^{10}$ Btu) of thermal storage.

For each application, one ur two specific storage techniques will be chosen. These systems will be selected using the following criteria:

1. engineering feasibility in the next five to ten years;

2. amount of detail availahle $n$ the cost and pcrformance of the system.

It should be possible to use one storage technique for many of the temperature regimes listed in the previous paragraph. 
REFERENCES, FOR SECTION 1

1. A. B. Newton, "Meeting U.S. Energy Requirements," ASHRAE J. $17(11)$ : 36 (1975).

2. J. E. Raetz, C. R. Easton, and R. J. Hall, "The Selection and Use of Energy Storage for Solar Thermal Electric Application," paper 759088, p. 576 in Rec. 10th Intersoc. Energy Convers. Eng. Conf., "Institute of Electrical and Electronics Engineers, Inc., New York (August 1975). 


\section{SOLAR ENERGY UTILIZATION IN RESIDENTIAL UNITS}

Solar energy can be utilized in residential units through its conversion to electricity to supply the electrical needs of the household and/or directly as thermal energy for space heating, space cooling, and domestic water heating. This section discusses the requirements of solar-thermal-electric conversion systems to provide the domestic electric load, the domestic water heating load, and the space heating and cooling (air conditioning) load for three categories of load types: a single-family detached residence, an apartment complex of 100 units, and a reference city of 30,000 residents, including single-family housing units, apartments, and any associated commercial establishments.

\subsection{Single-Family Residence}

Residential energy requirements for single-family housing units have been investigated and reported in ref. 1 . Detailed quantitative thermal analyses were performed on a typical single-family residence in the Baltimore-Washington area. Thermal modeling techniques were adopted to identify the energy profile of a typical residence and to evaluate concepts whereby the energy consumption could be minimized. As a point of reference for these analyses, a characteristic house was synthesized to represent current trends in residence construction and use of energyconsuming appliances.

The characteristic single-family detached dwelling was defined by a set of structural parameters and by a set of energy consumption parameters, wh1ch are listed in Table 2.1.

To perform a detailed energy analysis of a typiral residence and its components, specific internal load and strurtura1 parameters must he determined based on the description of a characteristic house such as is given in Table 2.1. The internal energy consumption parameters include the average annual energy inputs to the house due to the occupants and the use of appliances and lights. Although seasonal variations in the use of appliances and lights exist, data nbtained from the utilitico in the Baltimore-Washington area indicated that such variations are relatively small. Consequently, average daily energy inputs to the characteristic house for the use of appliances and lights were taken as $1 / 365$ of the annual values shown in Table 2.1. Figure 2.1 shows the average daily energy input profile for appliances, and Fig. 2,2 showo the profile for lights.

The approximate wattage rating and estimated annual kilowatt-hour consumption of electrical appliances under normal household use (1969 data) are given in Table 2.2.2 Tn 1969 the average all-elcctric-home customer used about $20,000 \mathrm{kWhr}$ of electrical energy. By 1990 the corresponding average annual use is expected to be about $33,000 \mathrm{kWhr}$. The hourly variation factors for particular load types can be as given in 
Table 2.1. Design parameters for the characteristic single-family detached dwelling in the Baltimore-Washington area

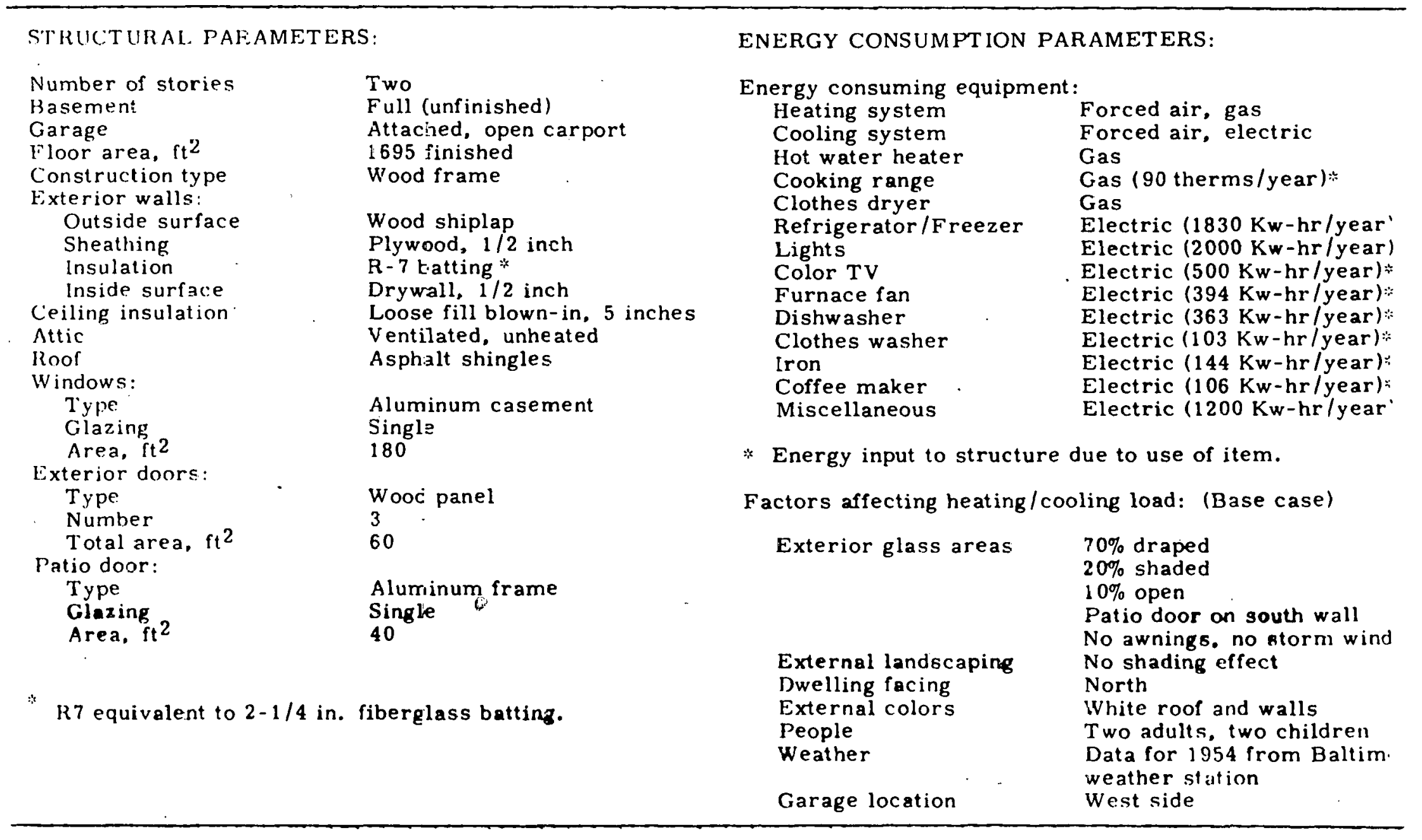

Source: Residentiai Energy Consumption, Single-Family Housing - Final

Report, HUD-HAI-2, Hittman Associates, Columbia, Md. (March 1973),

Table III, p. 13. 


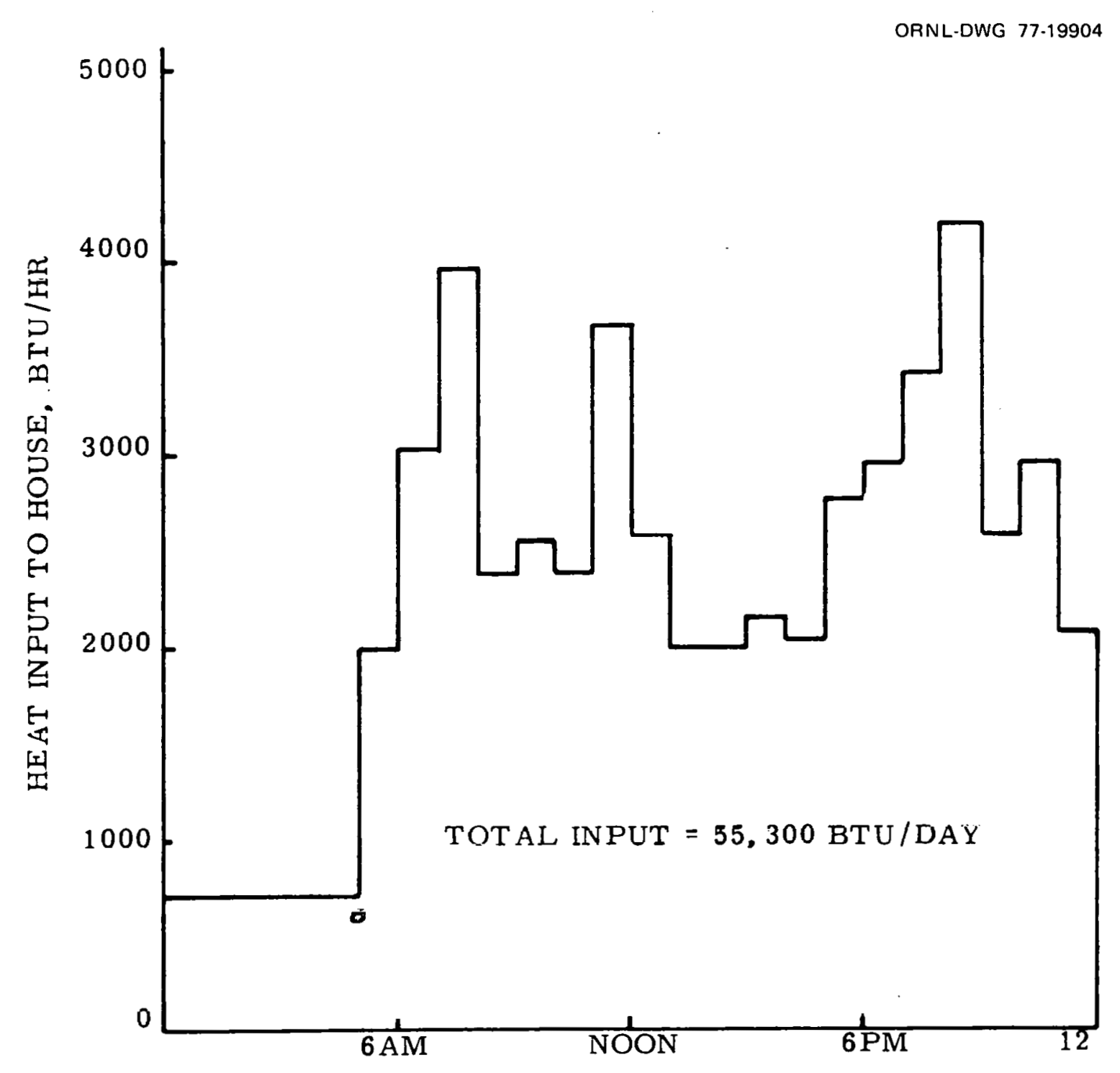

Fig. 2.1. Profile of the average daily heat input to the characteristic house due to the use of appliances. Source: Residential Energy Consumption, Ëirgle-l'amily llousing - Eiricil Repurl, HUD-HAI-2, H1ttman Associates, Columbia, Md. (March 1973), Fig. 10, p. 25. 


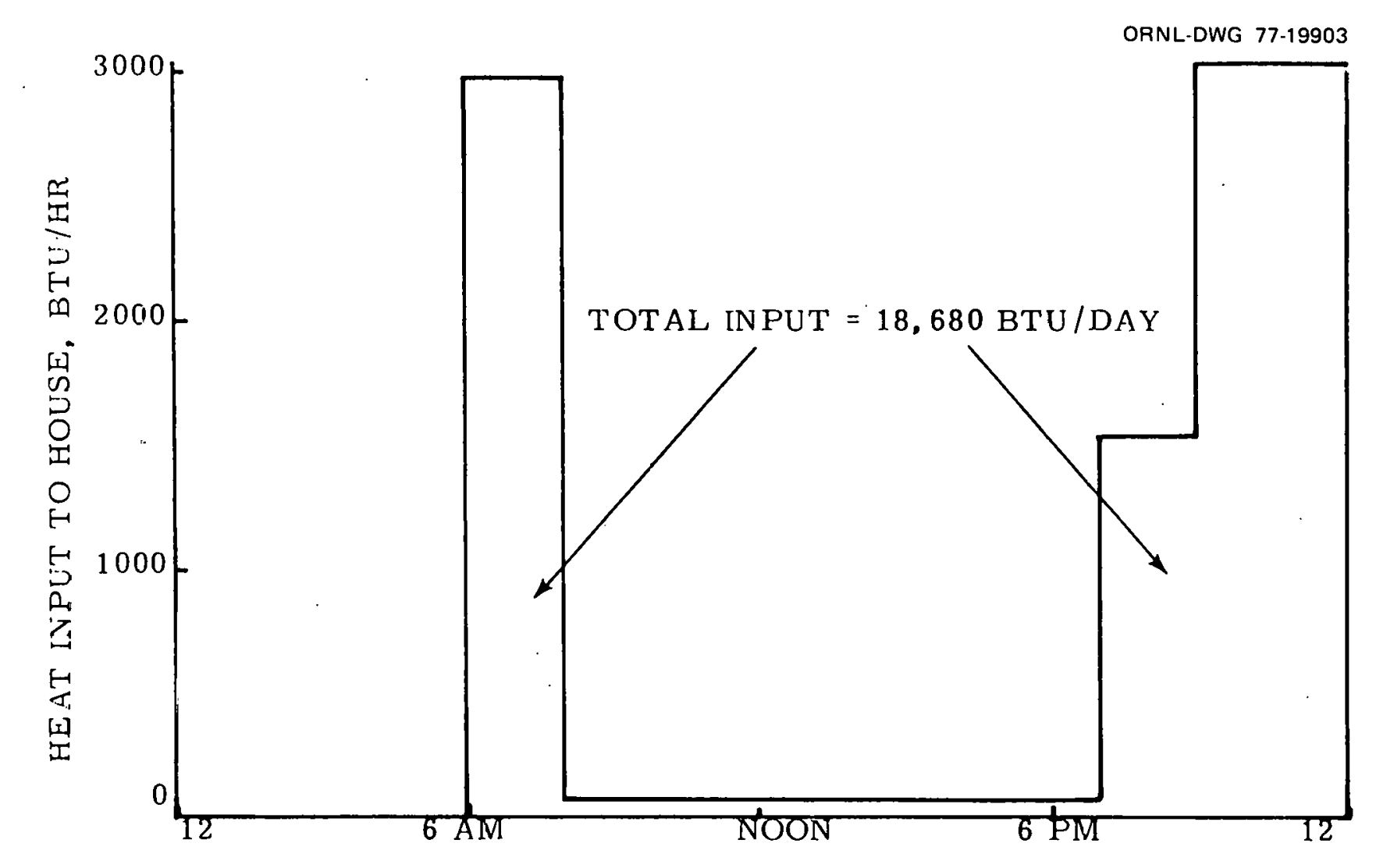

Fig. 2.2. Profile of the average daily heat input to the characteristic house due to the use of lights. Source: Residential Energy Consumption, Single-Fomily Housing - Final Report, HUD-HAI-2, Hittman Associates, Collumbia, Md. (March 1973), Fig. 11, p. 26. 
Table 2.2. Approximate wattage rating and estimated annual kilowatt-hour consumption of electrical appliances under normal use (1969)

\begin{tabular}{|c|c|c|c|c|c|}
\hline Appliance & $\begin{array}{l}\text { Average } \\
\text { Wattage }\end{array}$ & $\begin{array}{l}\text { Estimated KWH } \\
\text { Consumed Annually }\end{array}$ & Appliance & $\begin{array}{l}\text { Average } \\
\text { Wattage }\end{array}$ & $\begin{array}{l}\text { Estimated KWH } \\
\text { Consumed Annually }\end{array}$ \\
\hline Air Conditioner & & & Iron (hand)... & 1,088 & 144 \\
\hline (window)......... & 1,566 & 1,389 & Iron (mangle)......... & 1,494 & 158 \\
\hline Bed Covering . . . . . . & 177 & 147 & Oil Burner or Stoker... & 266 & 410 \\
\hline Broiler . . . . . . . . . & 1,436 & 100 & Radio $\ldots \ldots \ldots \ldots \ldots$ & 71 & 86 \\
\hline Carving Knife........ & 92 & 8 & Radio-Phonograph.... & 109 & livi \\
\hline Clock . . . . . . . . . . & 2 & 17 & Range............ & 12,207 & 1,175 \\
\hline Clothes Dryer. . . . . . . & 4,856 & 993 & Refrigerator ( $12 \mathrm{cu} \mathrm{ft}$ ). . & 241 & 728 \\
\hline Coffec Maker........ & 894 & 106 & Kefrigerator & & \\
\hline Cooker (eggs) $\ldots \ldots \ldots$ & 516 & 14 & (Frostless $12 \mathrm{cu} \mathrm{ft}$ )... & 321 & 1,217 \\
\hline Deep Fat Fryer....... & 1,448 & 83 & Refrigerator-Freezer & & \\
\hline Dehumidifier......... & 257 & 377 & $(14 \mathrm{cuft}) \ldots \ldots \ldots$ & 326 & 1,137 \\
\hline Dishwasher . . . . . . . & 1,201 & 363 & Refrigerator-Freezer & & \\
\hline Fan (attic) . . . . . . . & 370 & 291 & (Frostless $14 \mathrm{cu} \mathrm{ft}$ )... & 615 & 1,829 \\
\hline Fan (circulating) . . . . & 88 & 43 & Roaster............ & 1,333 & 205 \\
\hline Fan (furnace) . . . . . . & 292 & 394 & Sewing Macine....... & 75 & 11 \\
\hline Fan (roll-about). . . . . & 171 & 138 & Shaver........... & 14 & 18 \\
\hline Fan (window) ......... & 200 & 170 & Sun Lamp........ & 279 & 16 \\
\hline Floor Polisher. . . . . . . & 305 & 15 & Television (B\&W) .... & 237 & 362 \\
\hline Food Blender. . . . . . & 386 & 15 & Television (Color)..... & 332 & 502 \\
\hline Food Freezer ( $15 \mathrm{cu} \mathrm{ft})$ & 341 & 1,195 & Toaster........... & 1,146 & 39 \\
\hline Food Freezer & & & Tooth Brush........ & 7 & 5 \\
\hline (Frostless $15 \mathrm{cu} \mathrm{ft}$ )... & 440 & 1,761 & Vacuum Cleaner...... & 630 & 46 \\
\hline Fond Mixer......... & 127 & 13 & Vibrator........... & 40 & 2 \\
\hline Food Waste Disposer... & 445 & 30 & Waffle Iron.......... & 1,116 & 22 \\
\hline Frying Pan .......... & 1,196 & 186 & Washing Machine & & \\
\hline Germicidal Lamp : . . . & 20 & 141 & (Autnmatir) ... & 512 & 103 \\
\hline Grili (sandwich) . . . . . & $1,|h|$ & 33 & Washıng Machine & & \\
\hline Hair Dryer. . . . . & 381 & 14 & (Non-automatic) & 286 & 76 \\
\hline Heat Lamp (infrared). . & 250 & 13 & Water Heater & & \\
\hline Heat Pump. . . . . . . . & 11,848 & $16 ; \mathrm{M}^{3}$ & (Stañdàrd). . . . . . . & 2,475 & 4,219 \\
\hline Heater $($ radiant $) \ldots \ldots$ & 1,322 & 176 & Water Heater & & \\
\hline Heating Pad......... & 65 & 10 & (Quick Recovery)... & 4,474 & 4,811 \\
\hline Hot Plate.......... & 1,257 & 90 & Water Pump.......... & 460 & 231 \\
\hline Humidifier . . . . . . . . & 117 & 163 & & & \\
\hline
\end{tabular}

Source: The Technical Advisory Committee on Load Forecasting Methodology for the National Power Survey, "The Methodology of Load Forecasting," in The 1970 National Power Survey, Fart I, Federal Power Commission, Washington, D.C., 1970, Tablc 3.3, p. I-3-9. 
Table 2.3.3 This table shows the ratio of the demand of a particular type of load at hourly intervals to the maximum demand of that particular type of load.

\subsection{Multifamily Housing}

An analysis of multifamily dwelling units is given in ref. 4, which characterizes the design and construction of recent and new multifamily structures in the Baltimore-Washington area, including:

1. town house apartments - typically two-story structures with common party walls between dwelling units; each dwelling unit having a roof exposed to weather.

2. Zow-rise apartments (also called garden-type apartments) typically not more than four stories, without elevators and interior halls, and having enclosed or open stairwells which serve up to four apartments per floor.

3. high-rise apartments - typically structures with more than four stories, central elevators, interior halls, and central heating, ventilating, and air-conditioning systems.

The total energy consumption and types of energy-consuming equipment as a function of the energy type at the point of use was established for each of the multifamily housing types.

Figure 2.3 shows the appliances provided in multifamily projects in the eastern region of the United States. These are percentage values for appliances included in the rent or sale of a dwelling unit and do not include similar appliances that may be installed by the occupant. For example, occupant-owned refrigerators would probably raise the saturation level to $100 \%$ in town house and low-rise projects.

Figure 2.4 shows estimated annual electrical energy consumption for a11-electric master-metered apartment projects. This figure shows that the consumption on a per-square-foot basis depends on the size of the apartment and on the number of apartments per meter. The increase in energy consumption per unit area as the apartment area increases is probably primarily due to related income and life-style patterns of the occupants. The decrease in energy consumption per unit with an increase in the number of apartments per meter is primarily due to decreasing average heating and cooling requirements per apartment as the number of apartments per structure increases. This is because the percentage of end and Lup-floor apartmentc, which have the highest heat gains and losses, decreases as the number of apartments (and stories) increases. Also, as the number of units increases, the energy consumption per unit for building auxiliary equipment decreases.

Pertinent data were used to compute the electrical energy consumption for the characteristic low-rise and high-rise apartments on the assumbtion that they would be all-electric and master-metered. The results are shown in Fig. 2.5. In addition to the total consumption, 
Table 2.3. Hourly variation factors

\begin{tabular}{|c|c|c|c|c|c|c|c|c|c|c|c|c|}
\hline \multirow[b]{3}{*}{ Hour } & \multirow{3}{*}{$\begin{array}{l}\text { Lighting } \\
\text { and } \\
\text { misc. }\end{array}$} & \multirow{3}{*}{$\begin{array}{l}\text { Refrig- } \\
\text { erator }\end{array}$} & \multirow{3}{*}{$\begin{array}{l}\text { Home } \\
\text { freezer }\end{array}$} & \multirow[b]{3}{*}{ Range } & \multirow{3}{*}{$\begin{array}{l}\text { Air } \\
\text { condi- } a \\
\text { tíoning }\end{array}$} & \multicolumn{2}{|c|}{ Heat pump ${ }^{a}$} & \multirow{3}{*}{$\begin{array}{l}\text { House } \\
\text { heating }\end{array}$} & \multirow{2}{*}{\multicolumn{2}{|c|}{$\frac{\text { Water heater }}{\mathrm{aPWH}^{c}}$}} & \multirow[b]{3}{*}{$\begin{array}{l}\text { Uncon- } \\
\text { trolled }\end{array}$} & \multirow[b]{3}{*}{$\begin{array}{l}\text { Clothes } \\
\text { dryer }\end{array}$} \\
\hline & & & & & & \multirow{2}{*}{$\begin{array}{l}\text { Cooling } \\
\text { season }\end{array}$} & \multirow{2}{*}{$\begin{array}{r}\text { Heating } \\
\text { season }\end{array}$} & & & & & \\
\hline & & & & & & & & & $\begin{array}{l}\text { 3oth } \\
\text { elements } \\
\text { re- } \\
\text { stricted }\end{array}$ & $\begin{array}{c}\text { Only } \\
\text { bottom } \\
\text { elements } \\
\text { re- } \\
\text { stricted }\end{array}$ & & \\
\hline $12 \mathrm{M}$ & 0.32 & 0.93 & 0.92 & 0.02 & 0.40 & 0.42 & 0.34 & 0.11 & 0.41 & 0.61 & 0.51 & 0.03 \\
\hline 1 & 0.12 & 0.89 & 0.90 & $0.0 \div$ & 0.39 & C. 35 & 0.49 & 0.07 & 0.33 & 0.46 & 0.37 & 0.02 \\
\hline 2 & 0.10 & 0.80 & 0.87 & 0.01 & 0.36 & 0.35 & 0.51 & 0.09 & 0.25 & 0.34 & 0.30 & 0 \\
\hline 3 & 0.09 & 0.76 & 0.85 & 0.01 & 0.35 & 0.28 & 0.54 & 0.08 & C.17 & 0.24 & 0.22 & 0 \\
\hline 4 & 0.08 & 0.79 & 0.82 & 0.01 & 0.35 & 0.28 & 0.57 & 0.13 & C.13 & 0.19 & 0.15 & 0 \\
\hline 5 & 0.10 & 0.72 & C. 84 & 0.02 & 0.33 & 0.26 & 0.63 & 0.15 & C. 13 & 0.19 & 0.14 & 0 \\
\hline 6 & 0.19 & 0.75 & C. 85 & C. 0.5 & 0.30 & 0.26 & 0.74 & 0.17 & $0 .: 7$ & 0.24 & 0.16 & 0 \\
\hline 7 & 0.41 & 0.75 & 0.85 & C. 30 & 0.41 & 0.35 & 1.00 & 0.76 & 0.27 & 0.37 & 0.46 & 0 \\
\hline 8 & 0.35 & 0.79 & 0.86 & 0.47 & 0.53 & 0.49 & 0.91 & 1.00 & 0.47 & 0.65 & 0.70 & 0.08 \\
\hline 9 & 0.31 & 0.79 & 0.86 & 0.28 & D. 62 & 0.58 & 0.83 & 0.97. & 0.6 .3 & 0.87 & 1.00 & 0.20 \\
\hline 10 & 0.31 & 0.79 & 0.87 & 0.22 & 0.72 & 0.70 & 0.74 & 0.68 & 0.67 & 0.93 & 1.00 & 0.65 \\
\hline 11 & 0.30 & 0.85 & 0.90 & 0.22 & 0.74 & 0.73 & 0.60 & 0.57 & 0.67 & 0.93 & 0.99 & 1.00 \\
\hline $12 \mathrm{~N}$ & 0.28 & 0.85 & 0.92 & 0.33 & 0.80 & 0.84 & 0.57 & 0.55 & 0.67 & 0.93 & 0.98 & 0.98 \\
\hline 1 & 0.26 & 0.87 & 0.96 & 0.25 & 0.86 & 0.88 & 0.49 & 0.51 & 0.51 & 0.85 & 0.86 & 0.70 \\
\hline 2 & 0.29 & 0.90 & 0.98 & 0.15 & 0.89 & 0.95 & 9.46 & 0.49 & 0.55 & 0.76 & 0.82 & 0.65 \\
\hline 3 & 0.30 & 0.90 & 0.99 & 0.17 & 0.96 & 1.00 & 0.40 & 0.48 & 0.49 & 0.68 & 0.81 & 0.63 \\
\hline 4 & 0.32 & 0.90 & 1.00 & 0.24 & 0.97 & 1.00 & 0.43 & 0.44 & 0.33 & 0.46 & 0.79 & 0.38 \\
\hline 5 & 0.70 & 0.90 & 1.00 & 0.80 & 0.99 & 1.00 & 0.43 & 0.79 & $D$ & 0.09 & 0.75 & 0.30 \\
\hline 6 & 0.92 & 0.90 & 0.99 & 1.00 & 1.00 & 1.00 & 0.49 & 0.88 & 3 & 0.13 & 0.75 & 0.22 \\
\hline 7 & 1.00 & 0.95 & 0.98 & 0.30 & 0.91 & 0.88 & 0.51 & 0.76 & 0 & 0.19 & 0.80 & 0.26 \\
\hline 8 & 0.95 & 1.00 & 0.98 & 0.12 & 0.79 & 0.73 & 0.60 & 0.54 & 1.00 & 1.00 & 0.81 & 0.20 \\
\hline
\end{tabular}


Table 2.3 (continued)

\begin{tabular}{|c|c|c|c|c|c|c|c|c|c|c|c|c|}
\hline \multirow[b]{3}{*}{ Hour } & \multirow{3}{*}{$\begin{array}{l}\text { Lighting } \\
\text { and } \\
\text { misc. }\end{array}$} & \multirow[b]{3}{*}{$\begin{array}{l}\text { Refrig- } \\
\text { erator }\end{array}$} & \multirow[b]{3}{*}{$\begin{array}{l}\text { Fome } \\
\text { freezer }\end{array}$} & \multirow[b]{3}{*}{ Range } & \multirow{3}{*}{ 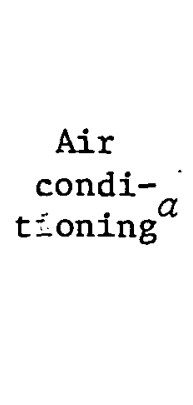 } & \multicolumn{2}{|c|}{ Heat pump ${ }^{a}$} & \multirow[b]{3}{*}{$\begin{array}{c}\text { House } \\
\text { heating }\end{array}$} & \multirow{2}{*}{\multicolumn{2}{|c|}{$\frac{\text { Water heater }}{b}$}} & \multirow[b]{3}{*}{$\begin{array}{l}\text { Uncon- } \\
\text { trolled }\end{array}$} & \multirow[b]{3}{*}{$\begin{array}{l}\text { Clothes } \\
\text { dryerd }\end{array}$} \\
\hline & & & & & & \multirow{2}{*}{$\begin{array}{r}\text { Cooling } \\
\text { season }\end{array}$} & \multirow{2}{*}{$\begin{array}{r}\text { Heating } \\
\text { season }\end{array}$} & & & & & \\
\hline & & & & & & & & & $\begin{array}{l}\text { Both } \\
\text { elements } \\
\text { re- } \\
\text { stricted }\end{array}$ & $\begin{array}{c}\text { Only } \\
\text { bottom } \\
\text { elements } \\
\text { re- } \\
\text { stricted }\end{array}$ & & \\
\hline 10 & 0.72 & 0.88 & 0.96 & 0.05 & 0.64 & 0.53 & 0.51 & 0.27 & 0.67 & 0.77 & 0.67 & 0.10 \\
\hline 11 & 0.50 & 0.88 & 0.95 & 0.04 & 0.55 & 0.49 & 0.34 & 0.23 & 0.54 & 0.69 & 0.59 & 0.04 \\
\hline $12 \mathrm{M}$ & 0.32 & 0.93 & 0.92 & 0.02 & 0.40 & 0.42 & 0.34 & 0.11 & 0.44 & 0.61 & 0.51 & 0.03 \\
\hline
\end{tabular}

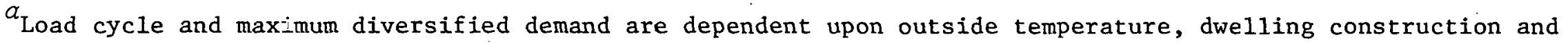
insulation, among other factors.

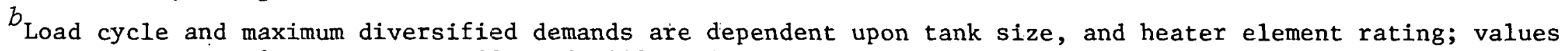
shown apply to 52-gal tank, 1500- and 1000-W elements.

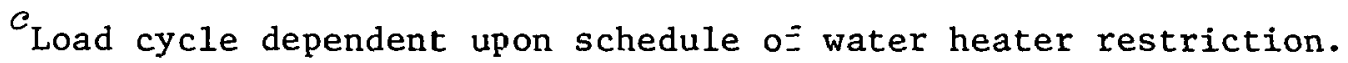

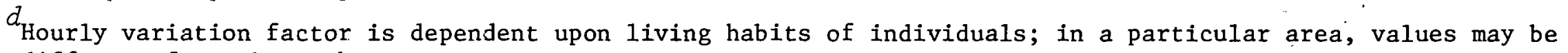
different from those shown.

Source: By permission from L. W. Manning, "Load Characteristics," in Electric Utility Engineering Reference Book-Distribution Systems, 1st Ed., Westinghouse Electric Corporation, Table 2, p. 37. 


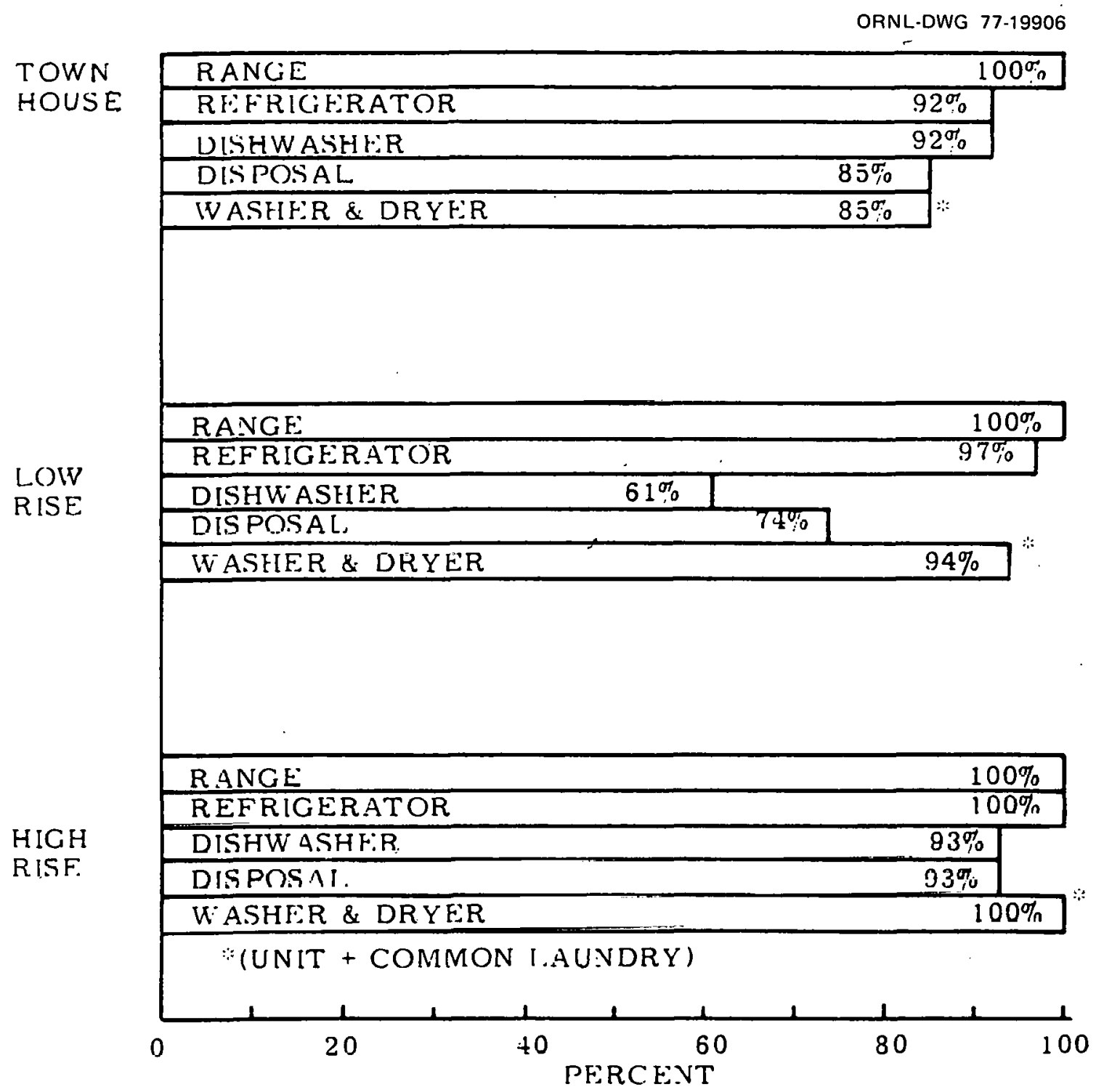

Fi.g. 2.3. Appliançes provided in multifamily projecto in the easterii region of the United States. Source: Residential. Fnergly Consumption, Multifomily Housing Data Acquisition, HID-HAI-3, Hittman Associates, Columbia, Md. (October 1972), Fig. 31, p. 37. 


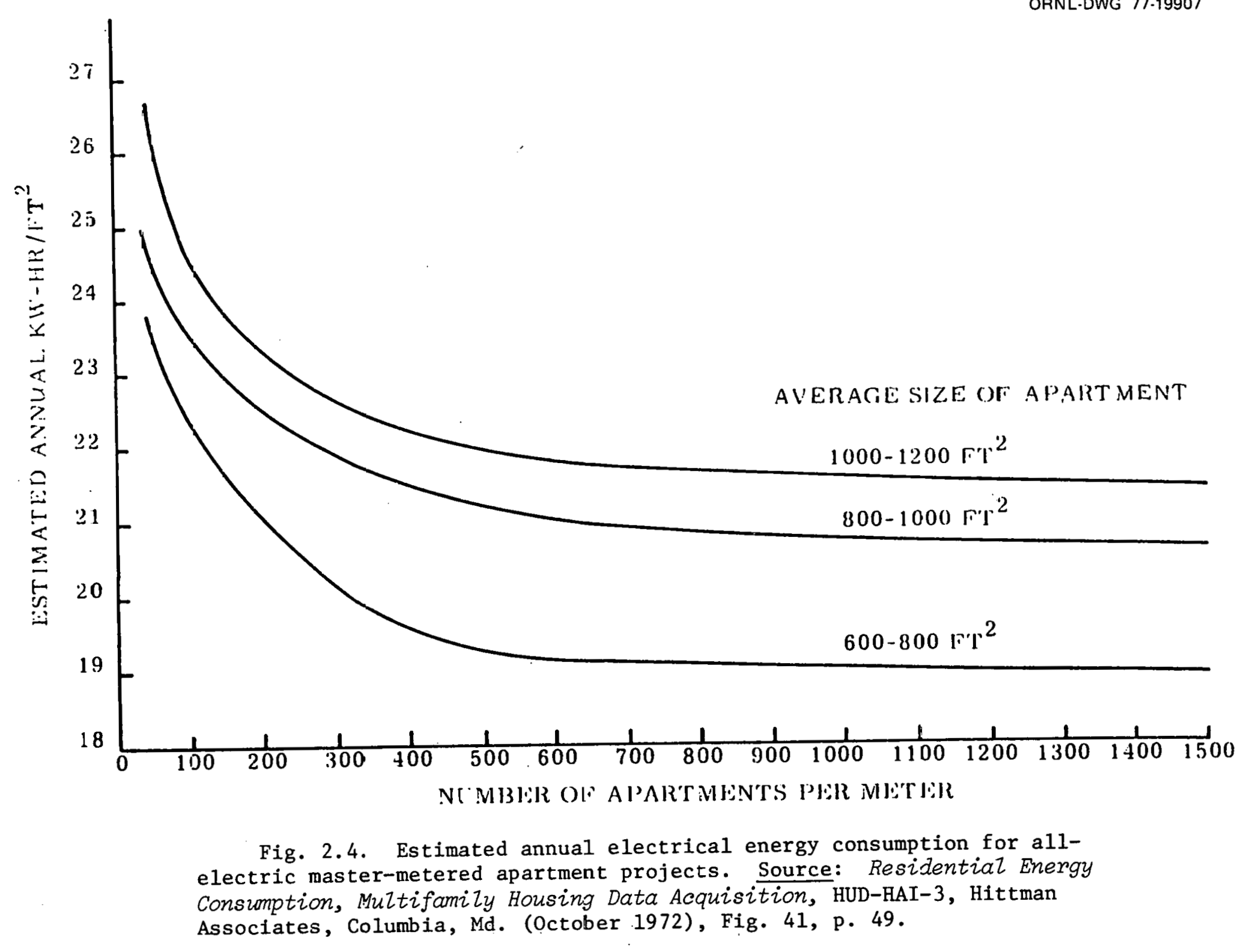




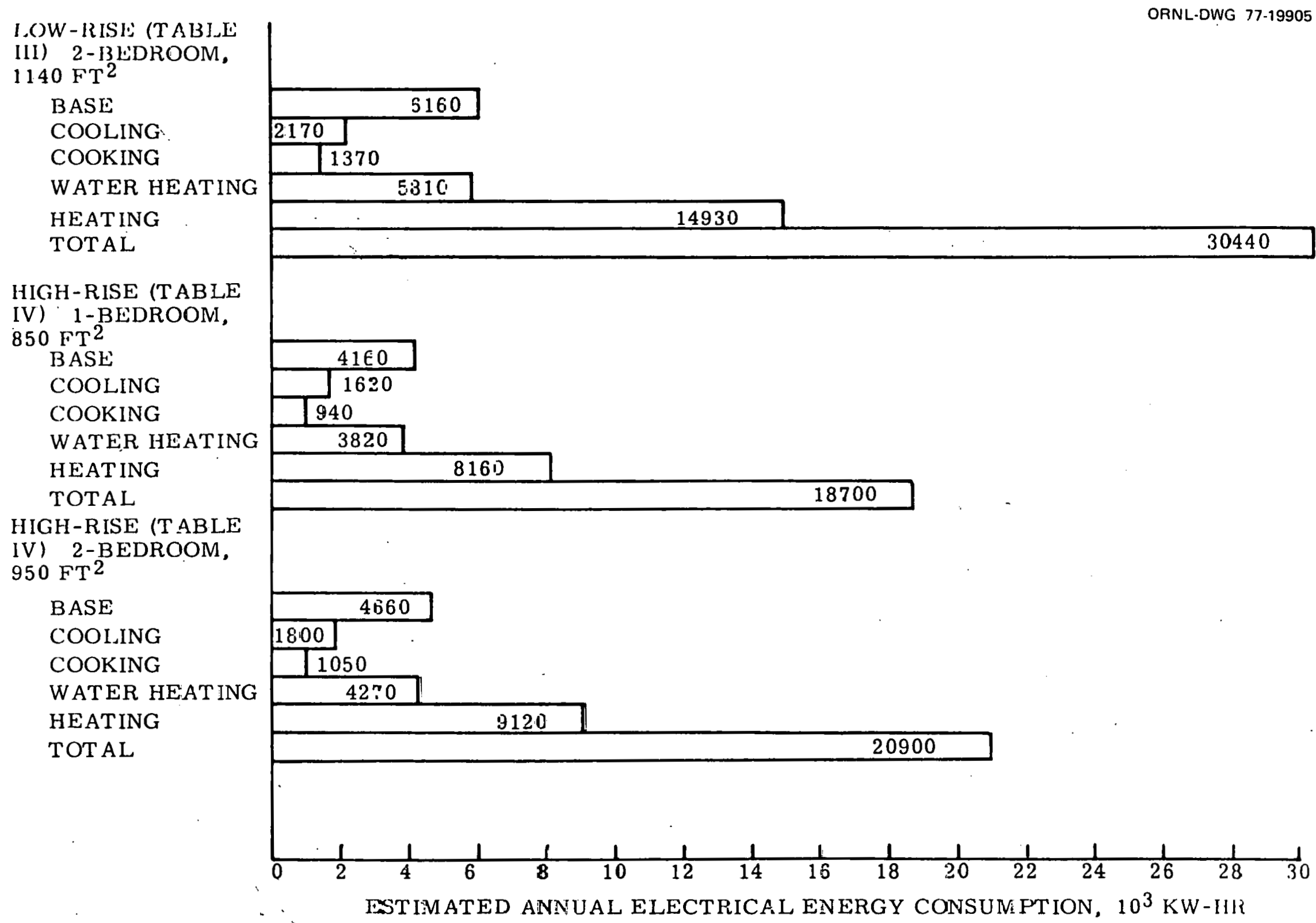

Fig. 2.5. Estimated annual eiectrical energy consumption for characteristic low-rise and high-rise apartments, assuming all-electric. Source: Pesidential Energy Consumption, Multifamily Housing Data Acquisition, HUD-HAI-3, Hittman Associates, Columbia, Md. (October 1972), Fig. 42, p. 51. 
the following components are identified: base, space cooling, cooking, water heating, and space heating. These are average values; higher values might be expected for the cooling and heating of end and topfloor apartments, whereas lower values might be expected for intermediate apartments. The base consumption includes lights and appliances in the apartments plus pro rata common consumption such as hall lights, building maintenance, elevators, and corridor air conditioning.

The Northern Natural Gas Company has metered the electrical energy demand and consumption of commercial buildings and correlated the information on the basis of building type and square feet of building area in a special report ${ }^{5}$ to the Group to Advance Total Energy. The electrical load profile for a typical operating day for an apartment building is presented in Fig. 2.6. This profile shows that the peak load for an apartment building occurs between 6 PM and 9 PM.

\subsection{Reference City}

The reference city is conceived as a hypothetical new community of 30,000 residents that contains a variety of single-family residential units, apartment units, and associated commercial establishments. Electrical energy would be distributed to the city from a strategically located solar energy center. The energy would be generated by a type of ground-based solar-thermal conversion system using conventional collectors, and the energy would be stored in one of the available thermal energy storage media. Conventional electric generating equipment would be used to produce the electrical energy.

From the standpoint of solar energy storage, the relationship between peak day load patterns and solar insolation must be established for the reference city solar energy center. The energy requirements for the center can be estimated from the kilowatt-hour residential and commercial consumption data in Table 2.4 (reprinted from ref. 6).

The solar energy center for the reference city should be designed to provide at least the average amount of electrictity required for the residential and commercial sectors. Table 2.4 shows that the sale of electrical energy to these sectors in 1975 was $1003.2 \times 10^{9} \mathrm{kWhr}$. The population of the United States at midyear 1975 was estimated at 213.5 $\times 10^{6}$ persons; therefore, the average per capita consumption of electrical energy by the residential and commercial sectors amounted to $4699 \mathrm{kWhr}$ per year per person. For a city with a population of 30,000 , the electric energy requirements should, therefore, amount to at least $141 \times 10^{6} \mathrm{kWhr}$ per year or an average of $3.86 \times 10^{5} \mathrm{kWhr}$ per day.

The demand of an installation or system is the load at the receiving terminals averaged over a specified interval of time. The maximum demand is the greatest of all demands that have occurred during the specified period of time. The diversified demand is the demand of a composite group of loads and is the value that must be considered in selecting the generator equipment for the reference city. A typical 


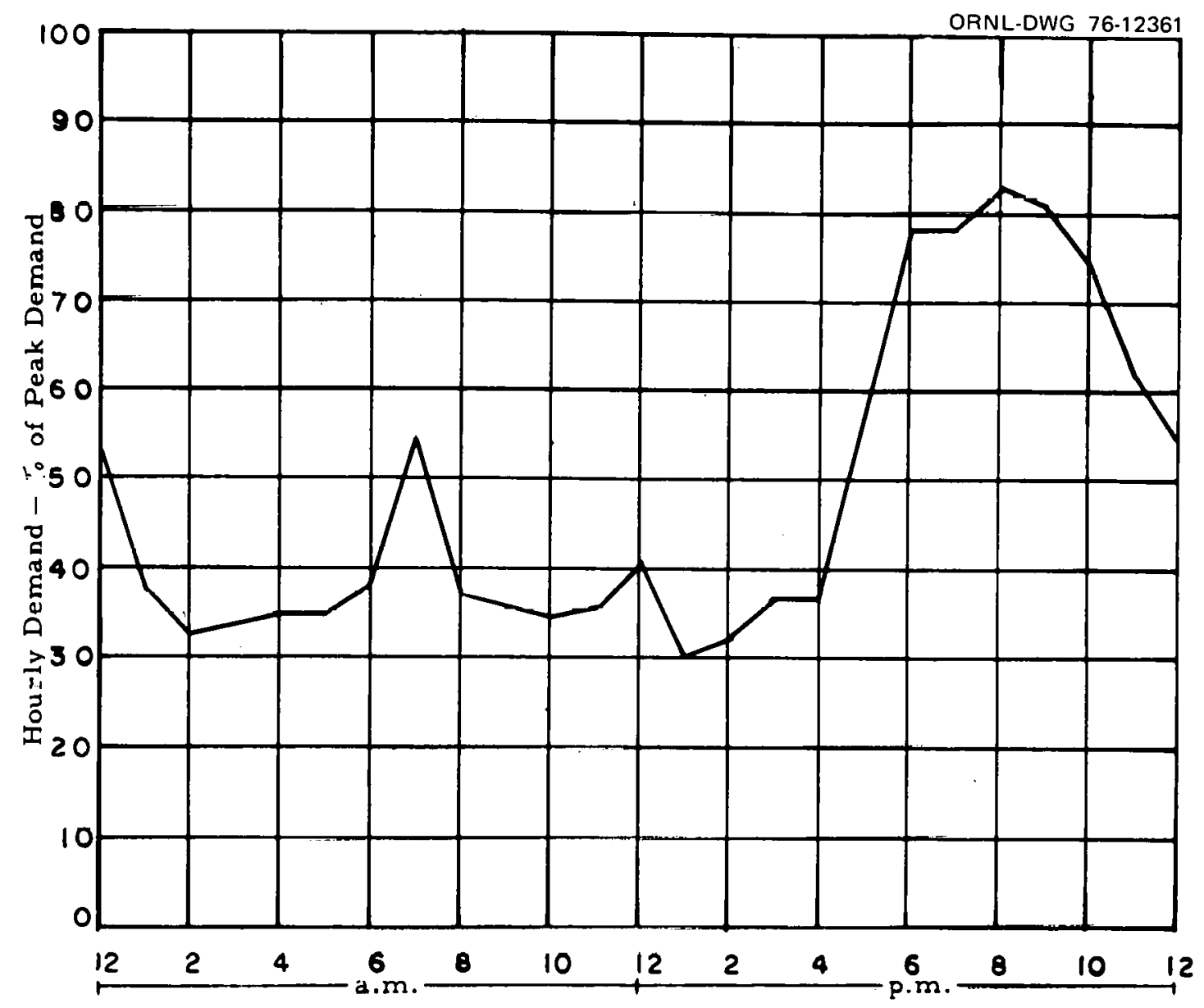

Time of Day - hr

Fig, 2.6. Electrical load profile for a typical operating day for apartment buildings. [Note: Peak operating demand $=2.18 \mathrm{~kW} / 1000 \mathrm{ft}^{2}$ (elevator peaks not included). Average daily load factor $=48.1 \%$.] Source: By permission from Group to Advance Total Energy, Elesetriono7. Load Profiles Hroject, Energy Information Center, Institute of Gas Technology (July 1966), Fig. S-286, p. 8. 
Table 2.4. Population, new households, and electric utility sales in the contiguous United States through 1995

\begin{tabular}{|c|c|c|c|c|c|c|c|c|}
\hline \multirow[b]{3}{*}{$\begin{array}{l}\text { Year } \\
\therefore\end{array}$} & \multirow{3}{*}{$\begin{array}{l}\text { Population at } \\
\text { mid-year, } \\
\times 10^{6}\end{array}$} & \multicolumn{2}{|c|}{ New households } & \multirow{2}{*}{\multicolumn{5}{|c|}{ Electric utility sales, $10^{9} \mathrm{kWhr}$}} \\
\hline & & \multirow{2}{*}{$\begin{array}{l}\text { Dwelling } \\
\text { units, } \\
\times 10^{3}\end{array}$} & \multirow{2}{*}{$\begin{array}{c}\text { At } \\
\text { mid-year, } \\
\times 10^{6}\end{array}$} & & & & & \\
\hline & & & & Residential & Industrial & Commercial & Other & Total \\
\hline 1964 & 191.9 & 1563 & 56.5 & 262.0 & 409.4 & 183.5 & 35.5 & 890.4 \\
\hline 1965 & 194.3 & 1513 & 57.7 & 281.0 & 433.4 & 202.1 & 37.0 & 953.4 \\
\hline 1966 & 196.6 & 1196 & 58.6 & 306.6 & 465.1 & 225.9 & 41.5 & 1039.0 \\
\hline 1967 & 198.7 & 1322 & 59.6 & 331.5 & 486.0 & 242.5 & 47.0 & 1107.0 \\
\hline 1968 & 200.7 & 1545 & 61.2 & 367.7 & 518.8 & 265.2 & 50.6 & 1202.3 \\
\hline 1969 & 202.7 & 1500 & 62.5 & 407.9 & 557.2 & 286.7 & 55.4 & 1307.2 \\
\hline 1970 & 204.9 & 1469 & 63.8 & 447.8 & 572.5 & 312.8 & 58.3 & 1391.4 \\
\hline 1971 & 207.0 & 2085 & 65.2 & 479.1 & 592.7 & 333.8 & 60.9 & 1466.4 \\
\hline 1972 & 208.8 & 2379 & 67.1 & 511.4 & 639.5 & 361.8 & 65.0 & 1577.7 \\
\hline 1973 & 210.4 & 2058 & 68.7 & 554.2 & 687.2 & 396.9 & 64.9 & 1703.2 \\
\hline \multirow[t]{2}{*}{1974} & 211.9 & 1352 & 70.3 & 555.0 & 689.4 & 392.7 & 63.7 & 1700.8 \\
\hline & & & & Forecast & & & & \\
\hline 1975 & 213.5 & 1265 & 71.8 & 586.9 & 650.7 & 416.3 & 65.8 & 1719.7 \\
\hline 1976 & 215.1 & 1850 & 73.3 & 626.1 & 716.7 & 445.4 & 67.9 & 1856.1 \\
\hline 1977 & 216.8 & 2000 & 74.8 & 662.5 & 814.8 & 472.1 & 70.2 & 2019.6 \\
\hline 1978 & 218.6 & 1900 & 76.2 & 699.2 & 878.9 & 500.5 & 72.5 & 2151.1 \\
\hline 1979 & 220.5 & 1850 & 77.6 & 734.2 & 893.3 & 528.0 & 74.9 & 2230.4 \\
\hline 1980 & 222.5 & 1850 & 79.0 & 770.0 & 971.4 & 554.4 & 77.4 & 2373.3 \\
\hline 1981 & 224.5 & 1825 & 80.4 & 806.0 & 1073.4 & 582.1 & 80.0 & 2541.5 \\
\hline 1982 & 226.5 & 1825 & 81.8 & 842.0 & 1153.0 & 611.2 & 82.7 & 2688.9 \\
\hline 1983 & 228.5 & 1825 & 83.1 & 877.7 & 1198.1 & 641.8 & 85.5 & 2803.1 \\
\hline 1984 & 230.5 & 1800 & 84.4 & 913.8 & 1303.1 & 670.7 & 88.3 & 2976.0 \\
\hline 1985 & 232.5 & 1830 & 85.7 & 950.5 & 1404.6 & 700.8 & 91.3 & 3147.3 \\
\hline 1990 & 242.0 & 1800 & 91.7 & 1151.2 & 1877.0 & 873.4 & 110.5 & 4012.0 \\
\hline 1995 & 250.0 & 1800 & 97.7 & 1507.1 & 2455.4 & 1168.5 & 134.8 & 5265.8 \\
\hline
\end{tabular}

Source: By permission from "26th Annual Electrical Industry Forecast," Electr. World, 184(6): 35-50 (1976). 
weekday load pattern of a metropolitan district utility is shown in Fig. 2.7,7 which illustrates the method of determining the maximum demand of a diversified group of loads such as would be characteristic of the reference city having residential, commercial, and some industrial loads.

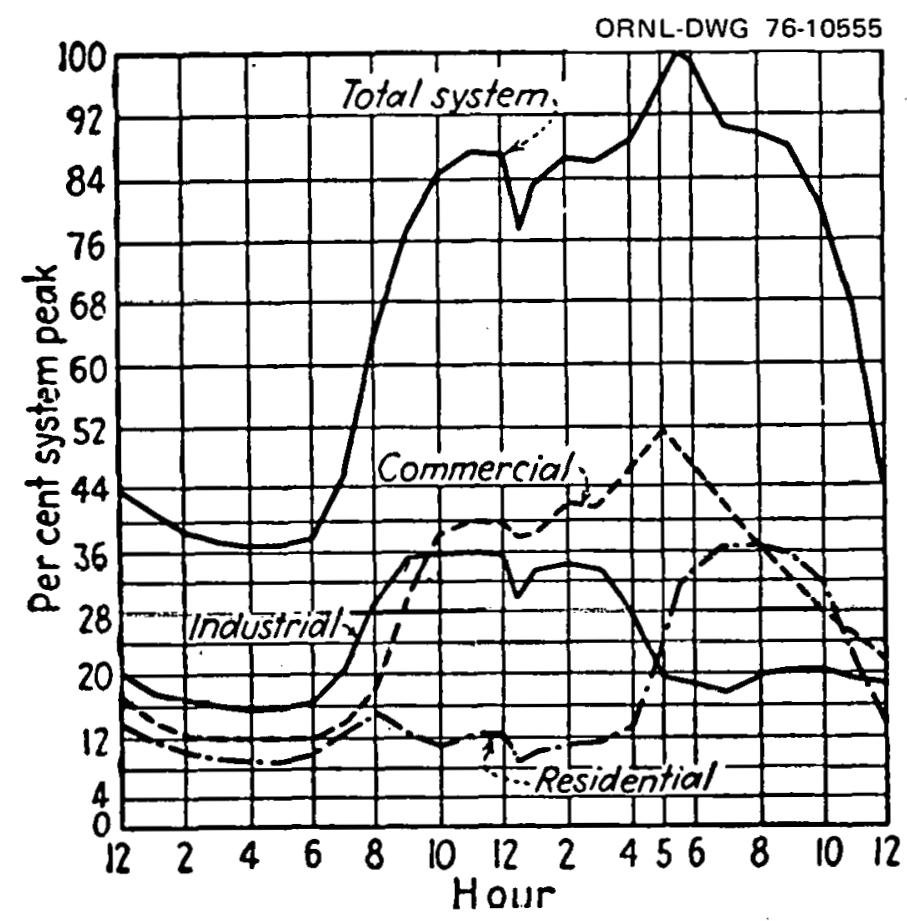

Fig. 2.7. Characteristic metropolitan weekday load pattern. Source: By permission from D. G. Fink (ed.), Standard Handbook for Elootrioal Engineers, 10 th ed., McGraw-H111, New York, 1968.

The daily load curve is a composite of demands made by the various categories of consumers. Industrial users make their heaviest. demands in the morning, and a considerable part of the load has disappeared before demand for lighting in the afternoon nears its peak. Commerclal users make their heaviest demands in the afternoon and early evening. The highest demand for residential lighting occurs from 7:00 to 8:00 PM, when commercial demand has receded from its peak and is rapidly dissipating. Air conditioning is shifting these curves for some systems to create daytime peaks during hot weather. Electric house heating builds heavy evening and morning loads during cold weather.

Figure 2.8 from The 1970 National Power Sumey ${ }^{2}$ shows peak day load patterns for selected systems by Federal Power Commission region. As shown in Fig. 2.8, the energy and demand patterns generally change from 
ORNL-DWG $77-19912$
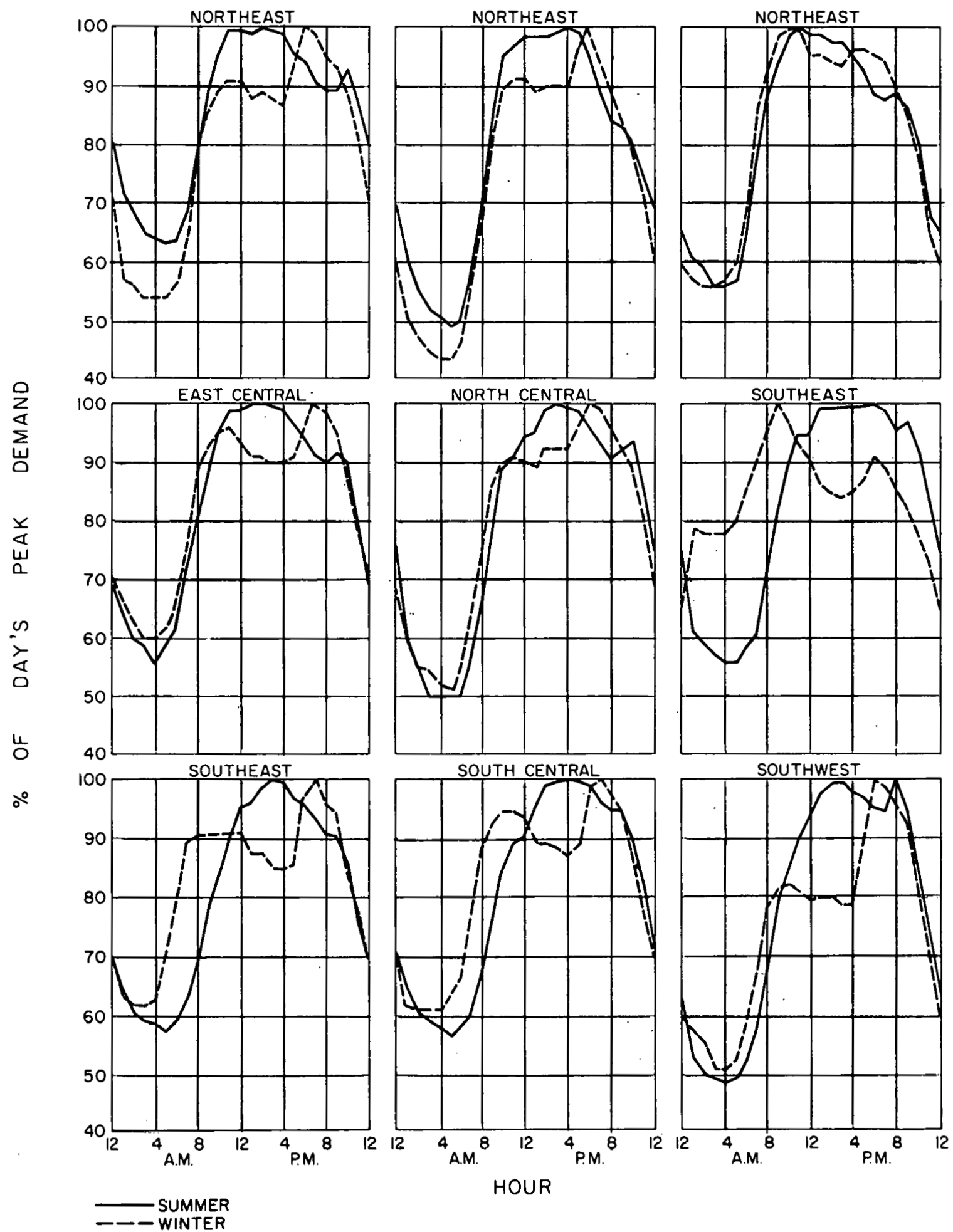

HOUR

Fig. 2.8. Peak day load patterns for selected systems (by FPC region). Snurse: The Technical Advisory Committee on Load Forecasting Methodology for the National Power Survey, "The Methodology of Load Forecasling," in The 1970 National Power Sumey, Part IV, Federal Power Commission, Washington, D.C., 1970, p. IV-4-22. 
season to season. Most of the changes are directly related to weather influences, such as temperature, wind, and light conditions. In the southern states an annual system peak usually occurs during periods of extremely high temperatures and is generally a daytime peak. In the regions where the annual system peak occurs in the winter, it frequently occurs in the late afternoon when darkness, low temperatures, and lighting combine to create a peak demand. In systems with heating loads, darkness and low temperatures have sufficient effect to cause the peak to occur in January or February. However, in systems with an even greater amount of heating load, the peak may shift to a morning hour. These kinds of effects of weather on system peak demand must be considered when analyzing the requirements for solar thermal energy storage. 
1. Residential Energy Consumption, Single-Family Housing - Final Report, HUD-HAI-2, Hittman Associates, Columbia, Md. (March 1973).

2. The Technical Advisory Committee on Load Forecasting Methodology for the National Power Survey, "The Methodology of Load Forecasting," p. IV-4-22 in The 1970 National Power Survey, Part IV, Federal Power Commission, Washington, D.C., 1970.

3. L. W. Manning, "Load Characteristics," p. 37 in Electric Utility Engineering Reference Book - Distribution Systems, Ist ed., Westinghouse Electric Corporation, East Pittsburgh, Pa., 1965.

4. Residential Energy Consumption, Multifamily Housing Data Acquisition, HUD-HAI-3, Hittman Associates, Columbia, Md. (October 1972).

5. Group to Advance Total Energy, Electrical Load Profiles Project, S-286, Energy Information Center, Institute of Gas Technology (July 1966).

6. "26th Annua1 Electrical Industry Forecast," Electr. World 184(6): 35-50 (1976).

7. D. G. Fink (ed.), Standard Handbook for Electrical Engineers, 10th ed., McGraw-Hill, New York, 1968. 


\section{SOLAR ENERGY CONVERSION SYSTEMS}

Four types of systems for the three categories of load types described in Sect. 2 are proposed for the direct conversion of solar energy. These systems, listed as follows, are considered to be within the realm of engineering feasibility and are conjectured to utilize solar energy at capital and operating costs that may be reasonable relative to comparable costs of other energy systems:

1. space and domestic water heating systems,

2. space cooling (air conditioning) systems,

3. total energy systems,

4. solar-electric power generation.

\subsection{Space and Domestic Water Heating Systems}

The simplest solar energy conversion systems are those designed for space and domestic water heating. In such systems, an inclined, southerly facing, flat collector is coupled with a heat storage system from which heat can be drained when required. A typical system for space heating of buildings by solar energy is shown in Fig. 3.1.1 This system contains four heat transfer loops:

1. collector-to-furnace plenum,

2. collector to storage,

3. storage-to-furnace plenum,

4. furnace plenum to conditioned space.

Thermal energy storage in this system can be accomplished by using either sensible heat or latent heat storage materials. Latent heat storage for solar space heating requires less volume than sensible heat storage, and the heat can be stored at essentially constant temperature. A disadvantage of latent heat storage, however, is the need for a heat exchanger between the heat transfer loop medium and the storage medium; in sensible heat storage, the two media (water) can be the same, thus avoiding the need for a heat exchanger. Latent heat and sensible heat storage units for solar heating of buildings are adequately described in refs. 1 and 2, The advantages va the disadvantages of thermal energy storage in water have been analyzed in ref. 3 .

\subsection{Solar Space Cooling (Air Conditioning) Systems}

An assessment of solar-powered cooling of buildings using Rankinecycle engines or absorption-cycle equipment is presented in ref. 4. In the case of the Rankine engine, the thermal energy is convereted to a mechanical output that is used to drive a vapor compression refrigeration machine to cool the building. In the case of the absorption equipment, the thermal energy input directly produces the cooling function. 

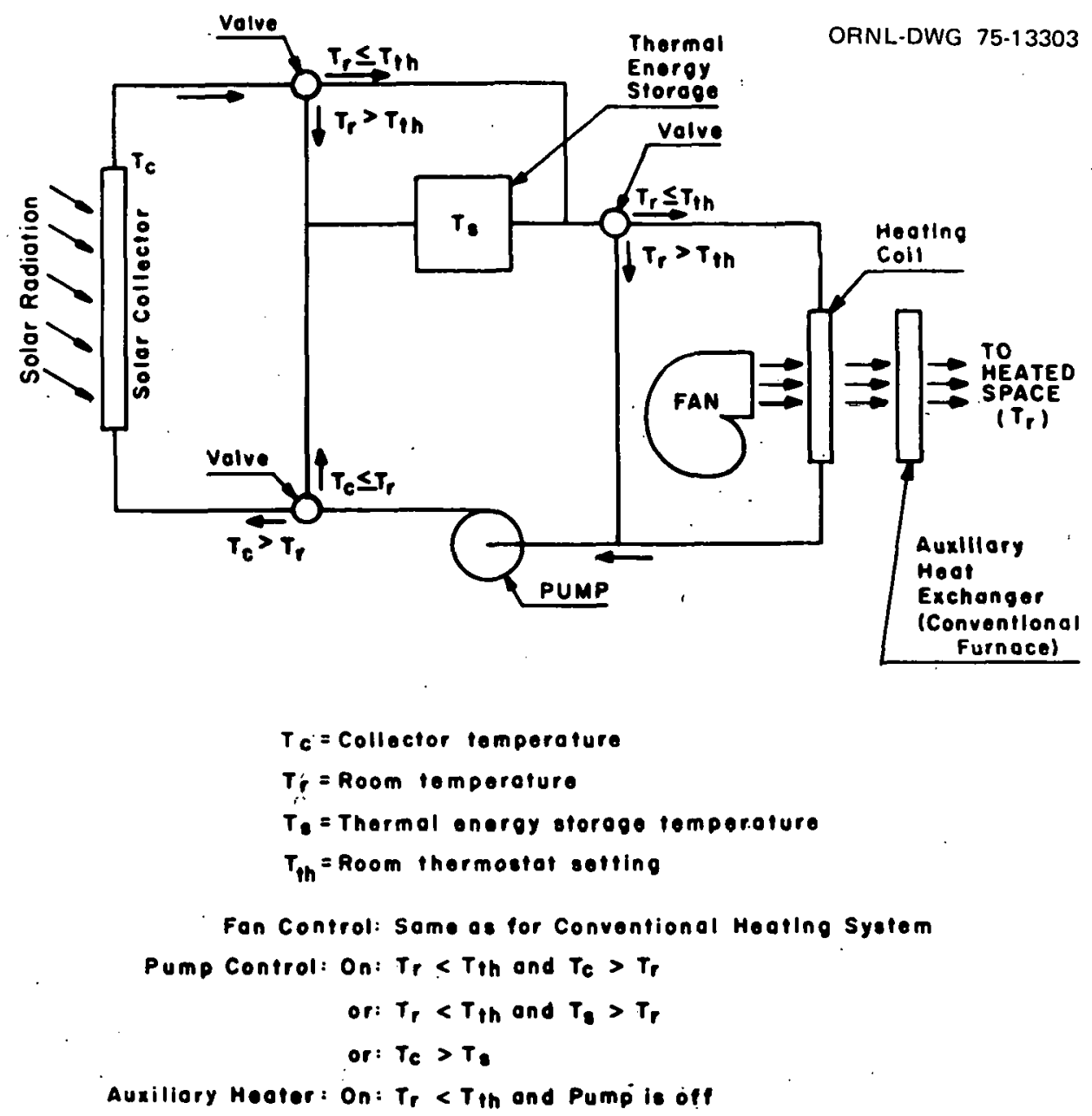

Fig. 3.1. Solar heating and thermal energy storage system diagram. Source: M. Altman et al., Conservation and Better Vtilization of Electric Power by Means of Thermal Energy Storage and Solar Heating, Final Summary Report, NSF/RANN/SE/GI27976/TR/73/5, University of Pennsylvania National Center for Energy Management and Power, June 31, 1973, Fig. 3-17, p. 3-34.

Figure 3.2 shows the system configuration for the concept using the Rankine cycle, and Fig. 3.3 shows the configuration for the solar absorption concept. These are basically the same, the absorption refrigeration machine being thermodynamically equivalent to a Rankine cycle driving a vapor-compression refrigeration cycle.

The high-temperature thermal storage provides a means of storing energy collected during the day for use at night. The low-temperature thermal storage provides a means of leveling the diurnal peaks in the cooling load. This permits the use of a smaller capacity refrigeration machine than would be necessary without storage. 


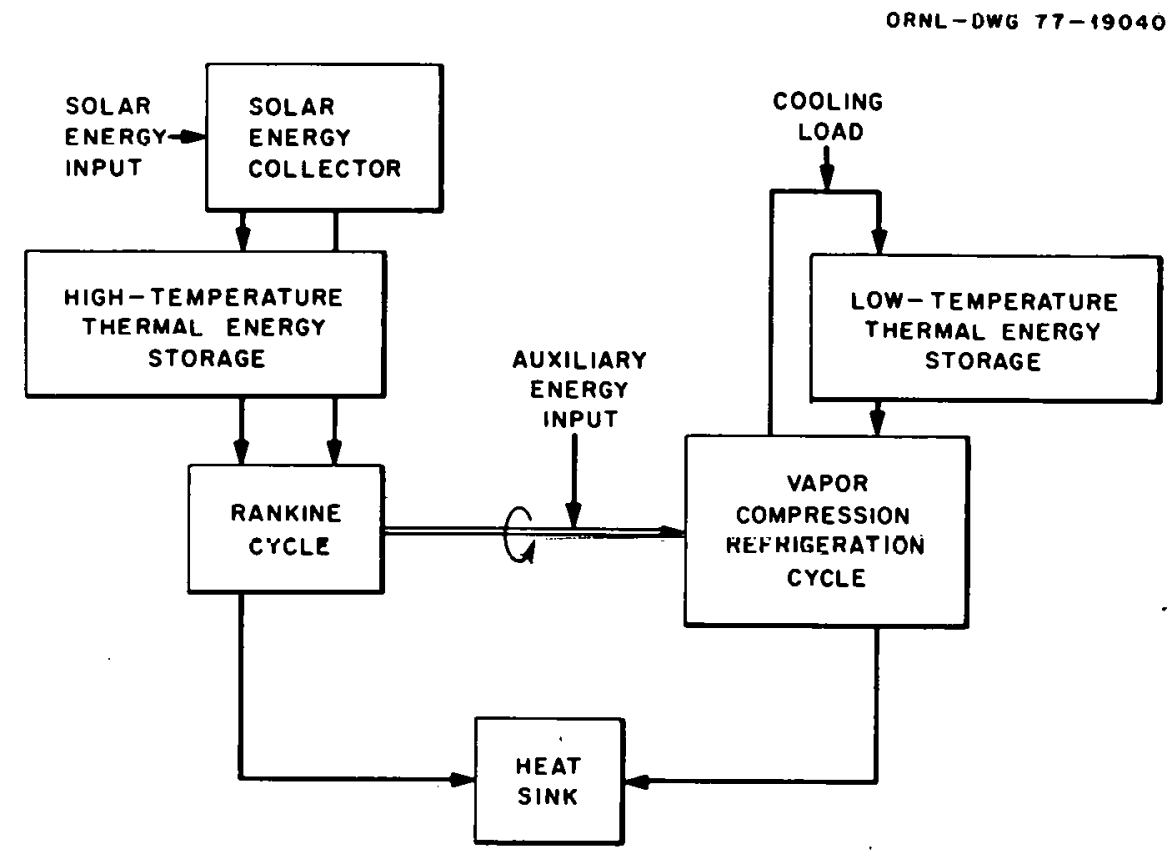

Fig. 3.2. System configuration for solar-powered cooling using the Rankine cycle. Source: Assessment of Solar-Powered Cooling of Buildings, Final Report, NST-RANN-75-012, Hittman Associates, Inc., Columbia, Md. (April 1975).

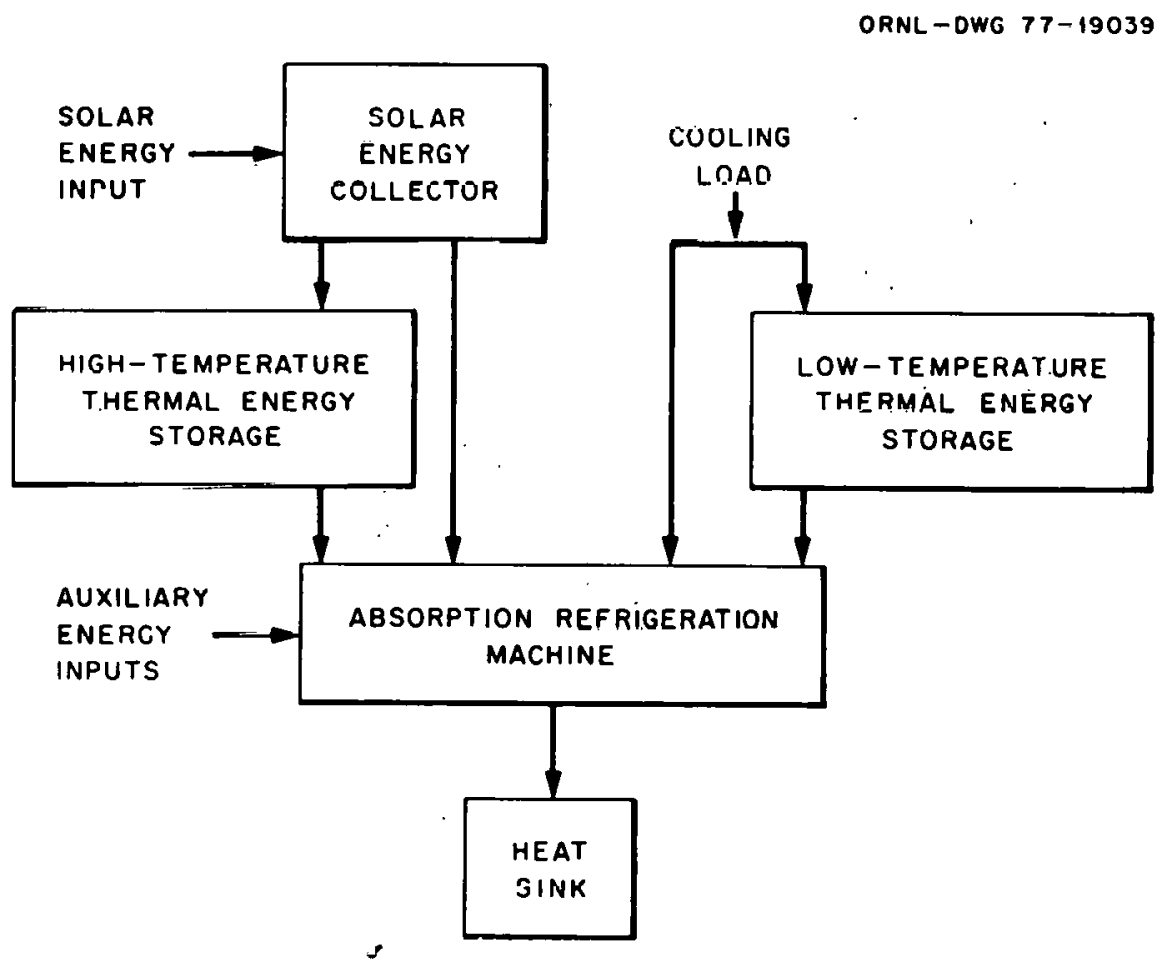

Fig. 3.3. System configuration for solar-powered cooling using the absorption cycle. Source: Assessment of Solar-Powered Cooling of Buildings, Final Report, NSF-RANN-73-012, Hittman Associates, Inc., Columbia, Md. (April 1975). 


\subsubsection{Solar Rankine cooling}

The Rankine cycle is a closed sequential series of thermodynamic processes that converts heat energy into mechanical energy. This conversion is effected by means of sequential changes of the state conditions of a circulating working fluid. In particular, the fluid undergoes changes in phase, pressure, and temperature.

In common with other cycles for the conversion of heat energy to mechanical energy, the Rankine cycle receives heat energy from a heat source at some temperature higher than the ambient temperature, converts some of this heat energy to mechanical energy, and rejects the remaining heat energy to a heat sink at or near the ambient temperature.

The basic components of a Rankine cycle are a boiler, an expander, a condenser, and a pump. The working fluid is evaporated in the boiler by means of a heat input, provided by solar energy in the case of the design mode of the solar Rankine concept. The vapor expands to a lower pressure and a lower temperature in the expander, thereby providing shaft power. The expander may take the form of a turbine, a piston engine, or a rotary engine. The vapor exhausted by the expander is converted back to the liquid state by giving up heat to a cooling medium, such as water or air, in the condenser. The liquid is then pumped to a higher pressure and returned to the boiler to complete the cycle. In the solar Rankine cooling concept, the net power output of the cycle is used to drive a vapor-compression refrigeration machine used for space cooling.

Water is the most common working fluid for Rankine cycle engines operating at high temperatures. However, for the low operating temperatures attainable with flat-plate and medium-concentration solar collectors, the thermal efficiencies obtainable with water are too low to make it a practical fluid. Numerous research studies have resulted in the identification of many organic fluids with thermodynamic properties suitable for low-temperature Rankine cycles. Chemical stability considerations generally limit maximum cycle temperatures for organic Fluids to approximately the 400 to $800^{\circ} \mathrm{F}$ range, depending on the fluid.

\section{2 .2 Solar absorption cooling}

The absorption refrigeration cycle driven by solar energy is an alternative to solar-powered cooling using the Rankine cycle. Although significantly different in their physical implementations, the absorption cycle and the vapor-compression cycle driven by a Rankine cycle are thermodynamically equivalent in the "black box" sense. That is, both are thermally driven and perform the function of pumping heat out of a cooled space into a heat sink. They differ primarily in the manner in which the refrigerant is compressed. In the Rankine cycle, the thermal input is converted to shaft power, which drives a vapor compressor; whereas, in the absorption cycle, the thermal energy is used to obtain a concentrated absorbent solution by evaporation of refrigerant. This concentrated solution is then used to absorb refrigerant vapor, thereby 
effecting the equivalent of compression because of the large reduction in the refrigerant specific volume as it passes from the vapor to the liquid state.

Absorption refrigeration systems operate on the basis of heatdriven, two-pressure cycles. In such cycles a vaporizable liquid is used as the refrigerant and a second liquid as the absorbent. The absorption cycle consists essentially of four basic components: absorber, generator, condenser, and evaporator.

The cycle contains two working fluids, the refrigerant and the absorbent, the latter being a solution containing both refrigerant and absorbent. The operation may be described by starting with the generator, which is on the high pressure side of the cycle. The generator receives dilute absorbent from the pump. As this solution passes through the generator, the thermal energy input causes evaporatinn of some of the refrlgerant, which is much more volatile than the absorbent, lliereby concentrating the absorbent. The refrigerant vapor flows into the condenser, where it is condensed by rejection of heat to a heat sink. The liquid refrigerant then flows through an expansion valve, with pressure reduction, to the evaporator. The evaporator, heat from the space to be cooled causes boiling and evaporation of the refrigerant at $1 \mathrm{ow}$ temperature. The refrigerant vapor then flows from the evaporator to the absorber.

In the absorber, the refrigerant vapor is dissolved in the absorbent, thereby causing a large decrease in the refrigerant specific volume, while maintaining the low pressure on this side of the cycle. The dilute solution is then pumped to the generator to continue the process. The absorption process is exothermic, the heat of absorption being equal to the sum of the heat of condensation of the vapor and the heat of dilution of the absorbent. This heat is discharged to a heat sink.

For generator temperatures on the order of $200^{\circ} \mathrm{F}$, such as might be provided by a flat-plate collector, the generator would be of the singleeffect type; that is, all of the refrigerant evaporation would occur in one vessel. If higher temperatures are available, such as from mediumconcentration collectors, more efficient designs are attainable at the expense of greater complexity by the use of multiple-effect generators. In such designs the generator has two or more sections, called effects, in which the refrigerant is evaporated at different temperatures.

To date the most satisfactory absorbent-refrigerant pair has been found to be lithium bromide-water.

The absorption cycle characteristic of primary importance is the coefficient of performance, which is defined as the ratio of the cycle cooling rate to the thermal energy input rate. Various studies have demonstrated that. the coefficicnt of. perfurmance is relatively insensitive to generator temperature, since changing this temperature changes the capacity rather than the coefficient. For single-effect, lithium 
bromide-water machines, the coefficient of performance is typically on the order of 0.65 to 0.70 , and for double-effect machines, it is on the order of 1.10 to 1.20 .

Because of their greater complexity, double-effect machines cost approximately twice as much as single-effect machines of equivalent capacity. Double-effect machines are not currently manufactured in capacities less than 65 tons.

\subsubsection{Combined solar heating and cooling system}

The economic prospects of a combination heating and cooling solar. system have been shown to be more favorable $e^{5}$ than for a system that can perform only one of the two functions. Figure 3.4 is a schematic dlagram of a combination heating and cooling solar system that is proposed to be retrofitted in the Towns Elementary School building in Atlanta, Georgia. ${ }^{6}$

About $10,000 \mathrm{ft}^{2}$ of flat plate solar collectors will be located on the roof of the one-story school building. Sunlight impinging on the collectors is estimated to heat circulating water to a temperature between 160 and $215^{\circ} \mathrm{F}$, which is then used to heat the school's domestic hot water supply and to power either the school heating system or air conditioning system. Excess hot water will be stored in four 6000-gal tanks and is estimated to be adequate to power the air conditioning equipment for several hours or to heat the building for two days. Existing heating equipment will provide the hot water needed during prolonged periods of cloudy weather.

Air conditioning equipment will consist of a nominal 100-ton, waterfired, lithium bromide absorption chiller that is operable with water input temperatures of between 200 and $245^{\circ} \mathrm{F}$. The maximum heat input required by the unit is 1.7 million $B t u / h r$, with a hot water flow rate of $240 \mathrm{gpm}$. During a 3-hr period around noon on a clear day, the collector system is estimated to supply about $2 \mathrm{million} B \mathrm{cu} / \mathrm{hr}$, which is slightly more than the peak thermal requircmente of the 100-ton unit.

\section{3 Solar-Integrated Utility Systems}

The electrical-thermal subsystem of an integrated utility system is a "total energy system" in which the normally wasted coolant and exhaust heat from engines that drive electric generators is recovered and used for space heating and cooling and domestic water heating.

The feasibility and benefits of solar energy utilization in Modular Integrated Utility Systems (MIUS) has been analyzed by Arthur D. Little, Inc. ${ }^{7}$ The effort included the identification of potential system concepts, evaluation of hardware status, and performance of weighted system evaluations to select promising system concepts deserving further study. 


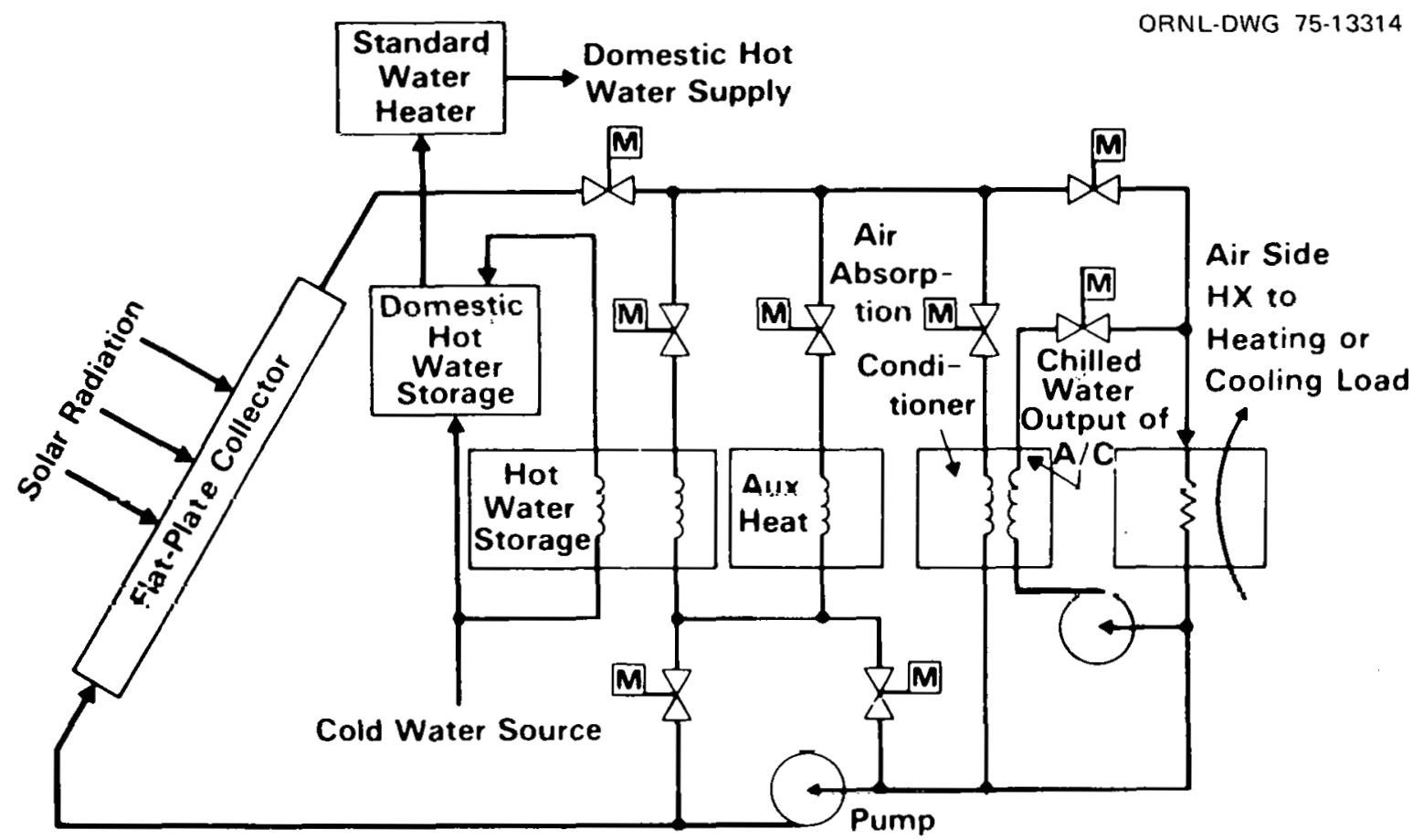

Fig. 3.4. Diagram of a solar heating and cooling system. Source:

By permission from R. T. Duncan, "Solar Energy Will Cool and Heat Atlanta School," ASHRAE J. 16(9): 47 (1974), Fig. 1.

The solar concepts selected to recelve a detailed review in ref. 7 included:

- Combined Solar and Waste-Heat Bottoming Rankine-Cycle Éngine Power Cencration

- Solar Domestic Hot Water Production and Snlar Hnt Water and Space Heating in the Single-Family Detached Residences, Including Heat Pump vitilization 
- Central Combined Heating and Cooling for High-Density Units

- Solar Desiccant Dehumidification of. Individual Buildings Connected to Central HVAC Subsystem.

Solar domestic water heating in the single-family detached residences was judged to have the highest economic potential of the solar concepts studied. The efficiency of the solar energy collection system is high in this application because:

1. the load has favorable characteristics (steady, low in temperature);

2. conventional water heating can account for approximately $18 \%$ of the annual MIUS electrical load, thereby offering the potential for significant electrical energy savings;

3. the technology required for solar water heating is less suphisticated than that required for other solar applications.

Solar water and space heating in single-family detached residences was also found to be very promising. This judgment was heavily weighted by the conventional heat-pump space heating system in the single-family residences and by the annual load, which accounts for about $15 \%$ of the MIUS annual electrical energy (and about $58 \%$ of the MIUS winter electrical energy).

Several solar heat-pump system arrangements were examined, and the impact of design trade-offs on cost-effectiveness (to the consumer) was analyzed. It was found that a system arrangement with an air-to-air heat pump operating as an independent auxiliary unit to the solar system will yield a lower net operating cost than can be achieved by a system arrangement with a water-to-air heat pump integrated with the solar storage tank.

The impact of solar heat-pump systems on the MIUS electrical load profile was also identified. In addition, heat-pump arrangements that could facilitate load management were discussed. However, the determination of the optimum MIUS load-management heat-pump arrangement required additional. analyses beyond the scope of the present investigation.

The central-station solar collection concept for high-density applications was not found to be attractive in the near term. The major reasons for this conclusion were marginal economics for central absorptinn chilling and a requirement for a deficit in MIUS high-temperature waste heat.

\subsubsection{The solar community concept}

The feasibility of using solar energy to provide most of the residential energy needs of a solar community was analytically investigated in ref. 8. Five different solar community concepts were analyzed and 
evaluated in terms of projected fund savings and annual total energy costs. The system that appeared most promising was a cascaded system using focused collectors, storage, and a derated turbine where the exhaust energy is "cascaded" into sensible heat storage for use in comfort conditioning.

The system using a focused collector and a derated turbine is shown schematically in Fig. 3.5. The components required for the system include: solar collectors located at each residence; centrally located intrinsic heat and/or sensible heat storage systems; central and/or subcentral fluid processing and distribution systems; central electric power generators; and central space heating, air conditioning, and hot water systems.

High quality heat storage in this system could be accomplished using the latent heat of fusion of an inorganic-salt. phase-change mate... rial (PCM) or one of the organic heat transfer oils. Storage of lowquality heat would be accomplished using the sensible heat of water.

The pertinent conclusions from this study ${ }^{8}$ are quoted as follows:

Results of the present study indicate that either the cascaded system or the hybrid systems could provide significant fuel savings and would have economic parity with today's energy systems if fuel costs should double or triple. Specifically, depending upon the system chosen, annual fuel savings of 45 to 65 percent could be obtained with economic parity occurring when fuel costs have increased to ahout $\$ 0.90 \mathrm{pcr}$ million DLu. Optimization of the subsystems, reducing fluid transmiseion cost by providing central rather than remote collection, and optimization on the basis of community and system size should provide an even more promising outlook.

The study indicates technology must be emphasized in the general areas of focused and flat plate collectors, thermal storage [emphasis added] (or other alternatives), energy distribution systems, Rankine turbine cycles and working fluids, and absorption alr conditioning systems. Furthermore, collection temperatures and collector efficiencies, turhine operating temperatures and efficiencies, storage temperatures and storage media, and absorptive air conditioning cycles should be traded off with overall system efficiency and technology requirements. Thic could lead lu a Lechinologically and economically feasible system for use in the near fulure.

\subsubsection{ORNL conceptual design study for a solar total energy system}

A conceptual design study for a state-of-themart solar total energy system has been prepared by the Energy Division of ORNL. ${ }^{9}$

The total energy system described in ref. 9 makes use of seven major components - the solar energy collector array, the thermal energy 


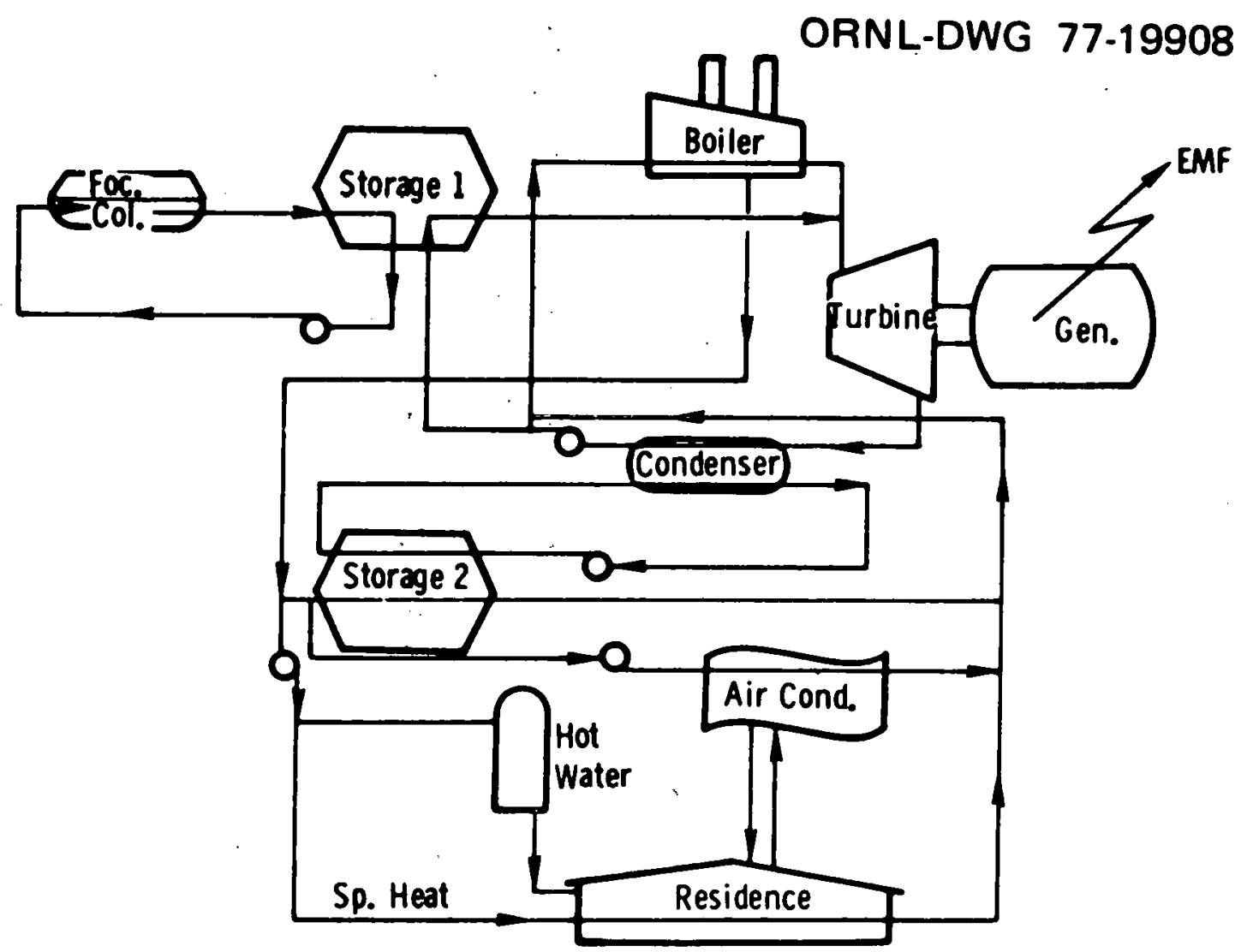

Fig. 3.5. Schematic of solar community using focused collection with derated turbine power generation, energy cascaded for space heating, etc. Source: By permission from R. B. Pope et al., "A Combination of Solar Energy and the Total Energy Concept - The Solar Community," Paper 739084 in Proc. 8th IECEC Conf., American Institue of Aeronautics and Astronautics, New York (August 13-17, 1973), Fig. 3, p. 306. 
storage tank, the building heating system, the domestic hot water system, the building air conditioning system, the electric power generating system, and an auxiliary oil-fired hot water heater to supplement the solar energy input during midwinter months when the household energy demand exceeds the capacity of the solar energy collection system.

A flow sheet showing the relation between the energy collector, the heat storage tank, and the various energy-consuming elements in the residence is presented in Fig. 3.6. The corresponding design data are presented in Table 3.1. Note that the integrated system has been designed so that the fluid in the solar-collector, heat-storage, energy utilization systems is kept in a closed circuit. Thus, it becomes possible to employ a $20 \%$ glycol-water solution that will not freeze in cold weather, and this can include an inhibitor an that corrosion inoidc the system will not be a problem. This fluid system would also include provisions for deaeration to assist further in minimizing corrosion inside the slosed systiam.

A Rankine-cycle turbine generator system employing an organic working fluid or a Freon could supply a substantial fraction of the electric power requirements of the household. A system of this sort has been under development at ORNL for use by the Navy in smal1, undersea, isotope power plants designed to produce a few kilowatts of electricity. ${ }^{10} \mathrm{~A}$ boiler-vapor separator unit suitable for the application of this study has been developed, and a survey of the state of the art of the type of small turbine or engine generator units required has been conducted.11 The survey indicates that any one of several units under development might be suitable for this residential application. The Rankine-cycle working fluid would be confined in a hermetically sealed system so that corrosion, buildup of deposits, and deterioration of the fluid should not be problems in the low-temperature system envisioned.

The clcctric power requilements for a typical residence were assumes to be $8000 \mathrm{kWhr} / \mathrm{hr}$, wh1ch is equivalent to $154 \mathrm{kWhr} /$ week or, in Btu equivalent, 525,000 Btu/week. If one assumes an overal1 thermal officiency of $7 \%$ for the Rankine-cycle and turbine generator system, ${ }^{12}$ this would impose a heat load of $7500 \mathrm{Btu} /$ week $\cdot \mathrm{ft}^{2}$ of the solar array. Note that the thermodynamic cycle assumed would reject its heat at $120^{\circ} \mathrm{F}$; hence, the heat rejected could be used for domestic water or space. heating.

The most effective use of the solar energy collected is made by cascading the heat flow as indicated in Fig. 3.6. For example, the heat input to the evaporacor in the refrigeration system is at a relatively high temperature level, and the water supplied to this system at $250^{\circ} \mathrm{F}$ would probably leave at a temperature of about $200^{\circ} \mathrm{F}$. Rather than recirculate it to the bottom of the solar energy storage tank and dissipate this heat at a low temperature level, during the daytime, when the load on the air conditioning system is high, the $200^{\circ} \mathrm{F}$ water can be recirculated directly to the solar energy collectors so that the amount of heat added in this array will not have to be as great. Similarly, the Rankine-cycle system for electric power generation would 
ORNL-DWG 77.19038

,

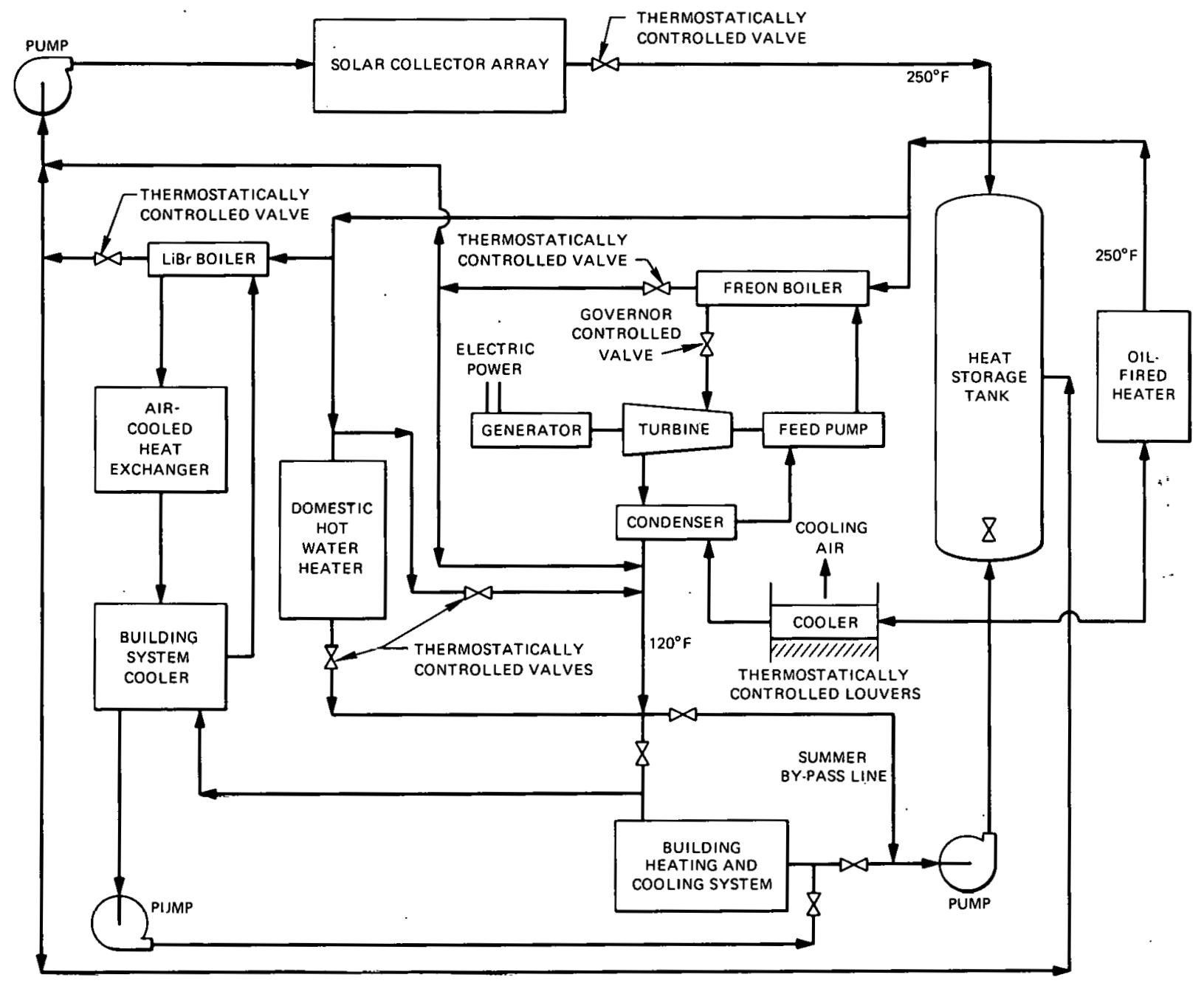

Fig. 3.6. Schematic diagram showing the proposed solar total energy system for a residence. 
Table 3.1. Total energy system with parabolic, cylindrical reflectors; a hot-water storage system; an absorption air conditioning system; and a Rankine-cycle electric generator

\section{Collector}

Total projected area of array, $\mathrm{ft}^{2}$

1000

Tilt angle of array, deg (from horizontal)

Collector element size, in.

Collector water exit temperature, ${ }^{\circ} \mathrm{F}$

Parabolic mirror azimuth angle

Parabolic mirror material

Number of glass cover plates

Collector tube OD, in.

Number of collector tube axial fins

45

$20 \times 72$

250

Adjustable

Alzak Al

1

0.50

2

0.5

25

Frartinn at day that array is effecilve, \%

0.87

0.95

0.90

.10

.10

$149 \times 10^{6}$

$193 \times 10^{6}$

Total heat collection at $210^{\circ} \mathrm{F}, \mathrm{Btu} / \mathrm{yr}$

Heat-Storage Tank

Tank height, ft

Tank diameter, ft

Tank capacity, $\mathrm{ft}^{3}$

Tank capacity, gal

Tank capacity at $250^{\circ} \mathrm{F}, 1 \mathrm{~b}$

Tank. Gapacity with $130^{\circ} \mathrm{F}$ Lemperature drop, Btu

20

4

240

2000

16,000

$2.08 \times 10^{6}$

Reference Design Residence (Knoxville, lat $=36^{\circ}$ )

Number of stories

Floor area per story, $\mathrm{ft}^{2}$

2

Building sim, $I t$

Heat loss, Btu/hr $-{ }^{\circ} \mathrm{F}$

Heat requirements for space heating, $a$ Btw/yr

Heat requirements for absorption air conditioning, $b$ $\mathrm{BLu} / \mathrm{yr}$

$a_{\text {Includes all hours per year in which the temperature is less than }}$ $65^{\circ} \mathrm{F}$.

3

Includes all hours per year in which the temperature is greater than $65^{\circ} \mathrm{F}$.
1600

$50 \times 32$

800

$71 \times 10^{6}$

$51 \times 10^{6}$ 
employ a boiler heated by high-temperature water from the solar energy storage system, but this water would leave the Rankine-cycle boiler at a temperature near $200^{\circ} \mathrm{F}$ and, hence, during the day could be used best by recirculating it.through the solar energy collection system. During the night, these $200^{\circ} \mathrm{F}$ water streams might be returned to a point near the middle of the heat storage tank.

As indicated above, the heat rejected from the Rankine cycle (i.e., most of the heat flowing into the boiler) could be rejected at $120^{\circ} \mathrm{F}$, an ideal temperature for building heating.

A review of energy storage systems indicates that the least expensive and most flexible for the solar collector proposed here is a hotwater tank. Experience with tanks of this sort, notably in Munich, Germany, indicates that the hot- and cold-water regions are stratified with very little mixing or conduction of heat between the two regions. This, of course, assumes a closed hot-water system in which hot water is added at the top of the tank as cold is withdrawn at the bottom and vice versa, with suitable baffles to minimize the turbulence associated with hot-water flow into the storage tank. A tank of this sort has the important advantage that the hot water can be stored at any desired temperature over quite a wide range, so that one is dealing with a constant temperature in the available heat supply at a level that may be changed with seasonal temperature demands. For example, it is important to have the heat stored at a temperature of at least $200^{\circ} \mathrm{F}$ in the summertime in order to drive an absorption air conditioning system, and the solar energy required to accomplish this can be readily obtained with the much higher solar energy input characteristic of summer operation. On the other hand, in the winter, when outside temperatures are low and the solar energy input is likely to be less than the space heating demand in the house, advantage can be taken of the fact that the solar energy collection efficiency can be increased by collecting and storing the heat at a lower temperature.

The cumulative effects of the numerous uncertainties expressed in ref. 9 could make a substantial difference in the attractiveness of the system. However, even after culsidering these uncertaintice, the proposed system appears to be sufficiently attractive to merit a definitive test. Such a test could be carried out by bullding a large solar energy collector array of the type proposed and coupling this to a hot-water storage system. This would permit an essentially full-scale test of the two major components. By conducting the test with a complete set of instrumentation, including measurements of direct and indirect solar radiation, definitive deductions could be made from the test results relative to the applicability of the system to the Knoxville area and to other locations. These data would also permit a very good approximation of the effect of changing from a solar energy collector of the type described here to some other type, such as a flat-plate collector with an elegantly treated surface that would permit collection of solar energy at temperatures of about $250^{\circ} \mathrm{F}$ with good efficiency. The data would also be directly applicable to the design of town houses and gàden apartments. 
No effort was made in this study to evaluate the performance of the Rankine-cycle electric power generation system as a function of such parameters as the peak temperature employed in the cycle, the condenser temperature, or the working fluid, because the scale of such a study was much beyond the scope of this effort. However, such a study would be essential to a definitive evaluation of the value of an electric power generation system in a solar total energy system of the type proposed herein. Such a study should begin with a survey of turbine and engine generator units available from vendors so that the actual performance characteristics of these units could be used in evaluating the effects of operating conditions and working fluids.

\subsection{Base-Load Power Generation Systems}

Engineering exporience in the gellerallon of base-load electricity from solar energy is quite limited. However, a few propusals for groundbased solar-electric conversion systems have been studied, two of which are described in refs. 13 and 14.

A typical solar conversion system employing a thermal energy storage (TES) device is illustrated in Fig. 3.7 with pertinent statepoint conditions indicated. 13 For this system it was aosumed that lie TES material could be maintained under thermocline conditions. In ref. 13, the authors discussed the normal and rcduced operalions of the system depicted in Fig. 3.7 for an assumed 1340-MW( $t$ ) peak power field, combined with a 300-MW(e) power plant. These discussions are quoted as follows:

A normal daytine operational mode is depicted in Fig. 3.7a, in which excess superheated steam is shunt fed to the thcrmal storage heater. A desuperheater is included in this configuration to prevent damage to the heat transfer fluid as a result of excessive charging temperature. Assuming the 1.34n-MW( $t$ ) poak powcr ficld coinsidered earlièr, combined with a $300-\mathrm{MW}(e)$ power plant, this mode of operation would continue until the thermal power level fell to 56 percent of the peak value. At this point, the shunt flow would have busn reduced to zero, with the entire steam flow being directed to the high-pressure turhine.

As the steam tlow-rate is reduced further due to a reduction in sular insolacion, the low solar power mode shown in Fig. $3,7 \mathrm{~b}$ ic usct. Tn Lhis mode, turbine extraction for teed water heating is successively reduced starting with the highest pressure feed water heater. The additional feed water heating is then accomplished by the thermal storage unit using the alternate feed water heater. Such a mode would exist unlil the steam rate fell to 39 percent of the peak value. At this point, the electrical generating capability would be reduced to approximately 88 percent of the design value. It should be noted that by adding a bypass 

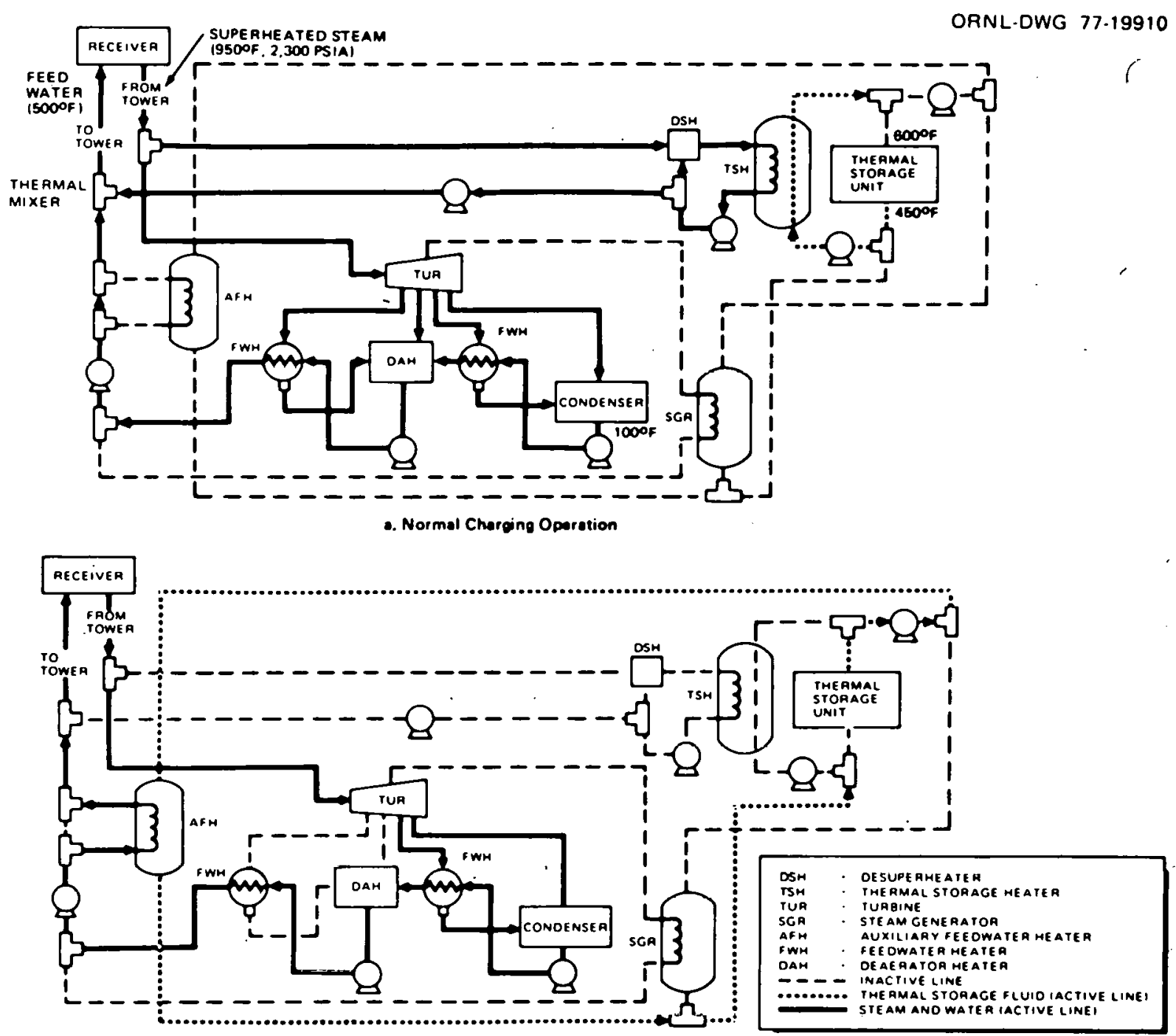

b. Low-Soler Power Oparation

Fig. 3.7. Schematic flow diagram of a typical base-load, solarelectric power conversion system. Source: By permission from J. E. Raetz, C. R. Easton, and R. J. Hall, "The Selection and Use of Energy Storage for Solar Thermal Electric Application," Paper 759088 in Rec. 10th Intersoc. Energy Convers. Eng. Conf., Institute of Electrical and Electronics Engineers, Inc., New York (August 1975), Fig. 8, pp. 579-80. 

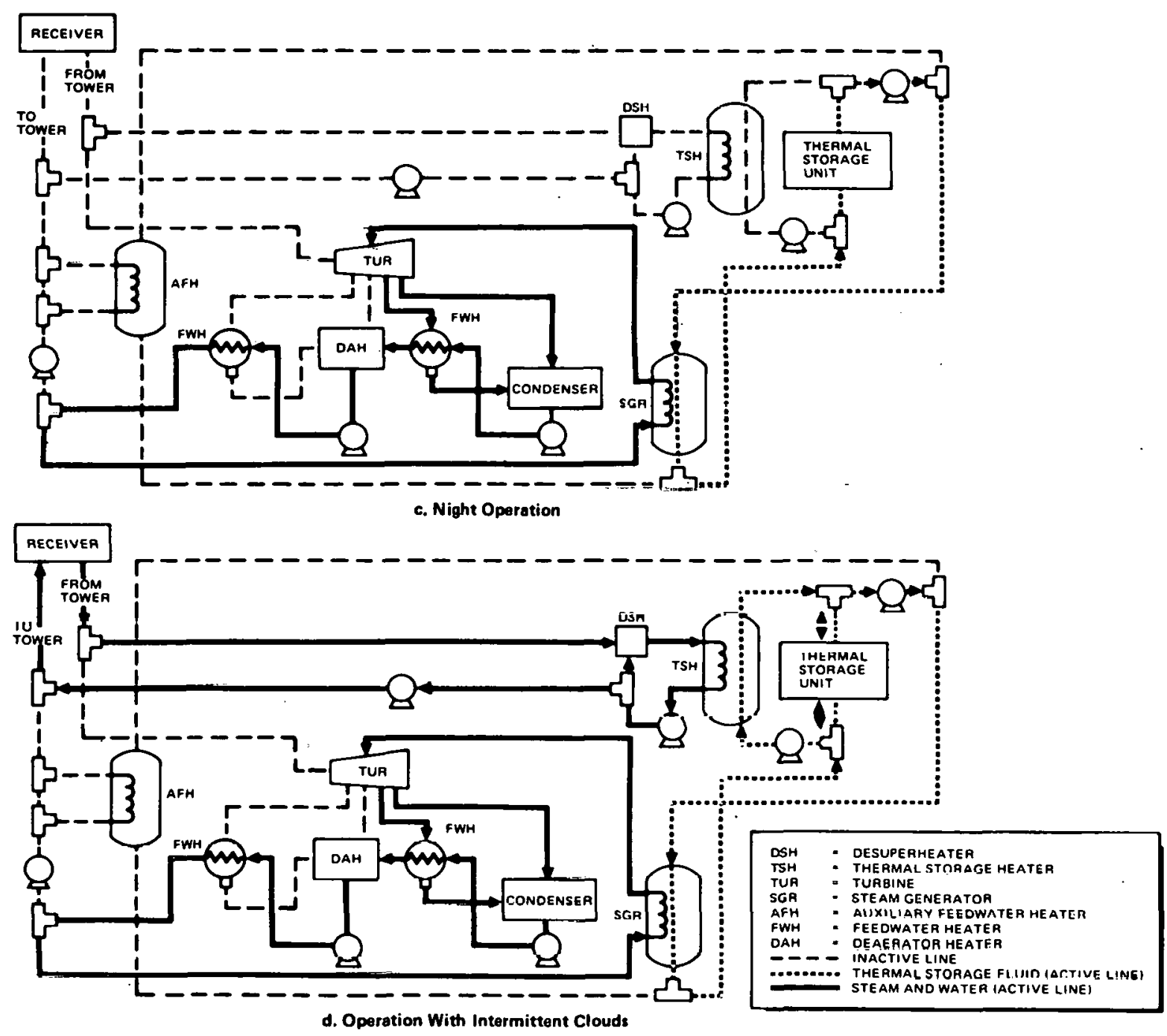

Fig. 3.7 (continued)

belween lhe water and steam lines upstream of the turbine, this mode could be used to provide thermal energy to the receiver during periods of nighttime shutdown.

As the steam rate falls further, the flow rate to the turbine is also rcduccd with a subsequeil luss in generating capacity. When the steam rate falls to 18 percent of peak power, the power plant efficiency has been reduced to 70 percent of its design value. At this point, the receiver loop is shut down and the turbogenerator draws its steam from the steam generator 
which is powered by the thermal storage fluid. Such a nighttime operational mode is depicted in Fig. 3.7c. Due to the degraded steam condition resulting from the two heat transfer operations (charging and discharging) associated with the thermal storage unit, the steam is fed directly into the lowpressure side of the turbine. The resulting generating capacity is approximately 70 percent of the design value.

During daytime periods in which severe transients in solar insolation occur as the result of frequent cloud passage, an alternate mode of operating (Fig. 3.7d) may be required to protect the turbine from unacceptable transients. In this case, all of the collected energy is shunt fed directly into the theraml storage unit while the turbogenerator is powered directly from the steam generator.

Preliminary design configuration features of a 100-MW(e), solar energy conversion power system and user applications for the direct solar installation are presented in ref. 14. The conversion system consists of a central power station surrounded by eight solar energy collection-concentration-conversion fields, which supply the required $1250-$ psi, $950^{\circ} \mathrm{F}\left(510^{\circ} \mathrm{C}\right)$, superheated steam for turbine generator operation. Boiler and superheater assemblies in each field are mounted on a 400-ft-high (121.9-m) tower at the center of the southern border of the field. In each field, 1840 mirrors perform the collectionconcentration junction with a single reflection of the solar energy.

A solar-energy conversion system has recently been proposed ${ }^{15}$ to generate electrical power and to provide temperature control for lifesupport systems. The system utilizes a Freon cycle and includes a boiler, a turbogenerator with heat exchanger, a regenerator and thermal-control heat exchangers, low-pressure and boiler-feed pumps, and a condenser. Although the system does not include the use of a solar heat storage subsystem, such a device could be incorporated in the solar heat input, and the system could be adapted for the generation of electrical power and for space and water heating in a single detached residence or in multiapartment complexes in the low- and/or intermediate-temperature regime.

Minto's Sun Power Systems, Inc., in Sarasota, Florida, has developed and recently announced the availability of an organic-fluid-driven engine that can be used to drive either an air conditioner compressor or a generator. ${ }^{16}$ A system is described in ref. 16 in which the engine is driven by refrigerant R-114 (Freon). In this system, water is heated from $165^{\circ} \mathrm{F}$ to $185^{\circ} \mathrm{F}$ in a flat-plate collector. The Freon is vaporized in a Freon boiler with the $185^{\circ} \mathrm{F}$ water, producing saturated $\mathrm{R}-114$ vapor at $180^{\circ} \mathrm{F}$ and 141 psia. This vapor then expands through the engine and exhausts at $120^{\circ} \mathrm{F}$, from which it is condensed at $80^{\circ} \mathrm{F}$ and returned to the Freon boiler. The system is claimed to generate $15 \mathrm{~kW}(\mathrm{e})$ with $180^{\circ} \mathrm{F}$ water from the collector. The system described in ref. 15 is quite similar to the system shown in Fig. 3.5, except that no thermal energy storage facilities were specified, and waste heat from the Freon engine was not utilized. 
REFERENCES FOR SECTION 3

1. H. G. Lorsch, Latent Heat and Sensible Heat Storage for Solar Heating Systems, NSF/RANN/SE/GI27976/TR/72/20, University of Pennsylvania National Center for Energy Management and Power (May 1974).

2. M. Telkes, "Solar Energy Storage," ASHRAE J. 16(9): 38-40 (1974).

3. G. C. Szego, Chairman, "Hot Water Storage Systems Group Report," p. 165 of Proceedings of the Workshop on Solar Energy Storage Subsystems for the Heating and Cooling of Buildings, NFS-RANN-75-041, American Society of Heating, Refrigerating, and Air Conditioning Engincero, Inc. (April 1975).

4. Assessment of Solar-Powered Cooling of Buildings - Final Report, NSF-RANN-75-012, Hittman Associates, Inc., Columbia, Md. (April 1975).

5. R. A. Tybout and C. O. G. Löf, "Solar House Heating," Nat. Resuru. J. $10(2)$ : 268-326 (April 1970).

6. J. I. Yellot, "Utilization of Sun and Sky Radiation for Heating and Cooling of Buildings," ASHRAE J. 15(12): 31-42 (1973).

7. Feasibility Study of Solar Energy Utilization in Modular Integrated Utility Systems - Final Report, Report 78036, A. D. Little, Inc., (June 30, 1975).

8. R. B. Pope, W. Y. Schimme L, Jr., D. O. Lee, W. H. McCulloch, and B. E. Bader, "A Combination of Solar Energy and the Total Energy Concept - The Solar Community," Paper 739084, Proc. 8th IECEC Conf., American Institute of Aeronautios and Astrnnalitiss, Now York. (August 13-17, 1973).

9. A. P. Fraas, G. Samuels, and J. V. Wilson, Conceptual Design for a Solar Total Energy System, unpublished ORNL report (1.974).

10. R. S. Holcomb and M. E. Lackey, Performance Characteristics of a Short Reentry Tube Stecon Generator at Low Stecm Output, ORNL/TM-.32.36, Oak Ridge National Laboratory (June 1971).

11. G. Samuels and R. S. Holcomb, Reference Design for an Isotope Power Unit Employing an Organic Rankine Cycle, ORNL/TM-2960, Oak Ridge National Laboratory (January 1971).

12. A. $\bar{P}$. Fraas, Review of Development Status of Smal.Z Turbine-Generator Units Suitable for the Navy Undersea Power Plant, ORNL/TM-3586, Oak Ridge National Laboratory (September 1972). 
13. J. E. Raetz, C. R. Easton, and R. J. Hall, "The Selection and Use of Energy Storage for Solar Thermal Electric Application," Paper 759088, Rec. 10th Intersoc. Energy Convers. Eng. Conf., Institute of Electrical and Electronics Engineers, Inc., New York (August 1975).

14. F. A. Blake and J. D. Walton, "Update on the Solar Power System and Component Research Program," J. Sol. Energy Sci. Technol. 17(4): 213-19 (September 1975).

15. "Solar Energy Conversion System," Mech. Eng. 97(2): 40 (February 1975).

16. E. F. Lindsley, "Sun-Powered Freon Engine Drives Air Conditioner or Generator," Eop. Sei. 208(2): 88-89 (February 1976). 


\section{CANDIDATE SOLAR THERMAL ENERGY STORAGE MATERIALS}

\subsection{Classification of Thermal Energy Storage Media}

Thermal energy in the form of either "hotness" or "coldness" can be stored in a variety of media as sensible heat by virtue of a change in temperature of the material or as latent heat of fusion in which the material changes from the liquid phase to the solid phase without an appreciable change in temperature. Both types of material have been used in thermal energy storage (TES) units.

In hotness storage, thermal energy is added to the TES medium, which ralses the temperature of sensible heat storage materials or melts the latent heat materials at constant temperature. In coldness storage, thermal energy is extracted from the medium, which results in a dccrcase in temperature of sensible heat storage materials or constant-temperature freezing of latent heat materials. In both cases, a temperature difference must exist between the thermal conveyance material and the TES medium to provide a driving force for heat transfer.

In addition to sensible heat and latent heat storage materials, several other media have been investigated as potential thermal energy storage materials, including the clathrate and semiclathrate hydrates, various metal hydrides, and heat storage based on inorganic chemical. reactions.

An ORNL report ${ }^{l}$ presents summaries of a considerable portion of published information on heat storage materials and devices, examines the technological aspects of their application in MIUS, ${ }^{*}$ provides some estimates of material and equipment costs, and proocnts conelusioiss reached about the most applicable types of matcrials and devices currently available for use in a MIUS.

In an article to become part of a chapter to be published in the 1974 applications volume of ASHRAE Handbook and Product Directory, Yellot ${ }^{2}$ has discussed heat storage systems and requirements for the utilization of solar energy for heating and conling of buildingo.

\subsubsection{Sensible heat storage materials}

The sensible heat storage capacity of materials is glven by the thermodynamic relation

$$
\Delta Q=m \int_{t_{1}}^{t_{2}} C_{p} d t,
$$

\footnotetext{
${ }^{*}$ Modular Integrated Utility Systems.
} 
where

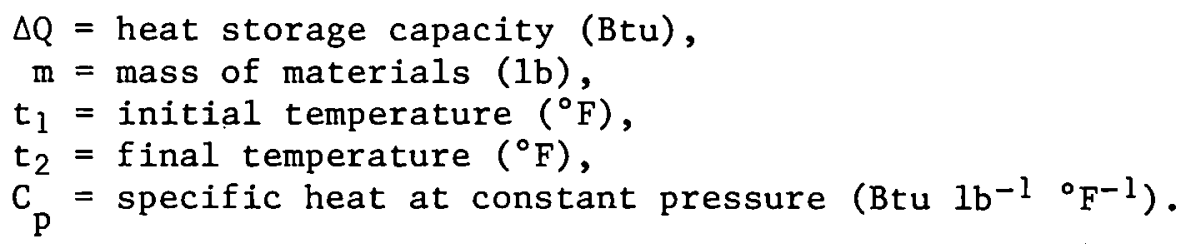

The specific heat usually varies with the temperature level of the material. However, if the specific heat does not vary appreciably between the initial and final temperatures, an average value for $\mathrm{C}_{\mathrm{p}}$ can be assigned, and the above expression becomes

$$
\Delta Q=m C_{p}\left(t_{2}-t_{1}\right)
$$

Since $m=\rho V$, where $\rho=\operatorname{density}\left(1 \mathrm{~b} / \mathrm{ft}^{3}\right)$ and $V=\operatorname{volume}\left(\mathrm{ft}^{3}\right)$,

$$
\Delta Q=\rho C_{p} V\left(t_{2}-t_{1}\right)
$$

The specific heat of water, for example, is $0.999 \mathrm{Btu} 1 \mathrm{~b}^{-1}{ }^{\circ} \mathrm{F}^{-1}$ at $140^{\circ} \mathrm{F}$, and increases to only $1.004 \mathrm{Btu} 1 \mathrm{~b}^{-1}{ }^{\circ} \mathrm{F}^{-1}$ at $200^{\circ} \mathrm{F}$ for an average specific heat of $1.0015 \mathrm{Btu} 1 \mathrm{~b}^{-1}{ }^{\circ} \mathrm{F}^{-1}$ between these limits. ${ }^{3}$

The product $\rho C_{p}$ is called the volumetric heat capacity, for which no commonly used symbol has been adopted. The limitations of thermal energy storage as sensible heat are set by the fact that the specific heats of usable materials range only from about $0.20 \mathrm{Btu} 1 \mathrm{~b}^{-1}{ }^{\circ} \mathrm{F}^{-1}$, for rocks and most other nonporous solid materials, to about $1.0 \mathrm{Btu} 1 \mathrm{~b}^{-1}$ ${ }^{\circ} \mathrm{F}^{-1}$ for water.

\subsubsection{Latent heat phase-change materials}

Latent heat phase-change materials (PCMs) possess the unique ability to absorb and liberate large quantities of heat without appreciable temperature change. Over 500 PCMs are reported in the reviewed literature as potential TES candidaces. ${ }^{4}$ The 500 potential PCMs were selected exclusively on the basis of heat of fusion and melting temperature. Based on the selection criteria given in Sect. 5, however, this number of candidate materials can be considerably reduced. Phase-change materials may be categorized into the following general types:

1. inorgaic salt hydrates and eutectics,

2. organic compounds and eutertics,

3. combined phase-change and sensible heat materials.

4.1.2.1 Inorganic salt hydrates and eutectics. Inorganic salt hydrates are solid compounds of inorganic salts and water with a definite number of moles of water forming crystalline solids of the general formula $\mathrm{S} \cdot \mathrm{nH}_{2} \mathrm{O}$, where $\mathrm{S}$ is an anhydrous salt [e.g., $\mathrm{Na}_{2} \mathrm{SO}_{4}$ (Glauber's salt)], and $n$ is the number of moles of water. At the phase-change 
temperature, the salt hydrate melts and dissolves in its water of hydration. In congruent melting, the salt hydrate forms a clear melt, or liquid phase, above the melting point. However, some sal,t hydrates are less soluable in their water of hydration and dissolve only partially, forming an incongruent melt. Since the solid phase is usually heavier than the liquid phase, it will settle to the bottom of the container.

4.1.2.2 Organic compounds and eutectics. A number of organic materials that have properties suitable for solar heating TES have been investigated. 5 Some properties of these materials which make them potentially attractive are the following:

high heat of fusion per unit weight, wide range of melting points ( 23 to $151^{\circ} \mathrm{F}$ ), nontoxic, noncorrosivo,

chemically inert and stable below about $750^{\circ} \mathrm{F}$ (above this temperature, complex reactions such as dehydrogenation, cracking, and aromatization could occur), negligible supercooling behavior, low vapor pressure in the melt., density range from 43.7 to $48.11 \mathrm{~b} / \mathrm{ft}^{3}$, commercially available at reasonable cost, high wetting ability, predictable and dependable.

On the other hand, some organics (paraffins) are flammable and undergo a relatively large ( $10 \%$ ) volume change upon melting, which could introduce problems in heat transfer. The rhnice of containoro for paraffins requires care, because paraffin can cause stress cracking in some plastics; metals such as aluminium or steel would prohahly be requircd.

4.1.2.3 Combined phase-change and sensible heat TES matcrials. Several TES materials that can be used in systems emplnying solid-1iquid phase change in addition to sensible heat storage are available. The heat storage capability of combined phase-change and sensible heat storage materials is given by the thermodynamic relation

$$
\Delta Q=M\left[\int_{t_{1}}^{t} c_{p s}(t) d \tau+\Delta h_{p c}-1 \int_{t_{p c}}^{t_{2}} c_{p L}(L) d t\right],
$$

where

$$
\begin{aligned}
\Delta Q & =\text { heat storage capacity } \\
M & =\text { mass of material, } \\
t_{1} & =\text { initial temperature, }
\end{aligned}
$$


$t_{p C}=$ phase-change (me1ting) temperature,

$\mathrm{LC}_{2}^{\mathrm{C}}=$ final temperature,

$C_{p s}=$ specific heat of the solid phase,

$\mathrm{C}_{\mathrm{PS}}^{\mathrm{PS}}=$ specific heat of the liquid phase,

$\Delta \mathrm{h}_{\mathrm{pc}}^{\mathrm{pL}}=$ latent heat of fusion.

\subsubsection{Clathrate and semiclathrate hydrates}

Clathrate and semiclathrate hydrates with melting points in the desired range have been investigated as potential TES materials. 5 The two main clathrate structures, types I and II, were defined as continuous solid-water structures containing closed cavities, within which are guest molecules that do not interact strongly with water. The semiclathrate structures were described as those in which the guest molecules directly participate in the water lattice.

According to ref. 5, the clathrate materials melt congruently at temperatures ranging between 33 and $88^{\circ} \mathrm{F}$, have heats of fusion in excess of $100 \mathrm{Btu} / 1 \mathrm{~b}\left(7000 \mathrm{Btu} / \mathrm{ft}^{3}\right)$, and are low-cost. However, some of the available clathrates might be eliminated as potential TES materials because of excessive corrosion or chemical activity and/or excessive pressure that would complicate the mechanical design of the TES containment device. No mention was made in ref. 5 of the applications of these materials; but because of their promising properties, further investigation of the clathrates as TES materials was recommended.

\subsubsection{Metal hydrides}

Because of the ease of reversibility of metal-hydrogen reactions and the relatively high heats of formation of metal hydrides, they have he.en proposed as possible TES materials in solar power applications. ${ }^{6}$ The concept proposed involves the use of solar heat to dissociate a hydride into a metal and hydrogen gas. The hydrogen gas would be stored, and the heat from the reaction would be recovered by allowing the metal and hydrogen to resombine according to the formula

$$
\mathrm{M}+\frac{\mathrm{x}}{2} \mathrm{H}_{2} \rightleftharpoons \mathrm{MH}_{\mathrm{x}}
$$

where the hydride, $\mathrm{MH}_{\mathrm{x}}$, is a definite chemical compound, and the value of $\mathrm{x}$ depends on the particular metal or alloy, $M$, that is used.

During periods of sunshine, the metal hydride would be heated to about $200^{\circ} \mathrm{F}$, and the d1sassnciated hydrogen gas would be stored in a suitable container. As the sun sets and the outside temperature decreases, the hydrogen would be bled into the metal, and the resulting heat could be used for hot water, space heating, or air conditioning. With this system, the heat may be recovered as required, and it can be stored indefinitely with no need for insulation. Metal-hydrogen systems are 
noncorrosive and are said to undergo indefinite cycling with no chemical degradation, which is a problem with some phase-change materials. Also, the high thermal conductivity of metal hydrides permits efficient heat transfer to the working fluid. An obvious disadvantage is the need to store pressurized hydrogen adjacent to living quarters.

\subsubsection{Inorganic chemical reactions}

A solar heat storage concept based on the heat of hydration of certain inorganic oxides, principally $\mathrm{MgO}$ and $\mathrm{CaO}$, which form the hydroxides $\mathrm{Mg}(\mathrm{OH})_{2}$ and $\mathrm{Ca}(\mathrm{OH})_{2}$, respectively, as the result of hydration, is described in ref. 7. The requirements and capabilities of this method of energy storage are summarized as follows:

1. Principles:

Collection and storage of heat:

$$
\begin{aligned}
& \mathrm{Mg}(\mathrm{OH})_{2}+\text { heat } \rightarrow \mathrm{MgO}+\mathrm{H}_{2} \mathrm{O}\left(\text { at } 375^{\circ} \mathrm{C}\right), \text { or } \\
& \mathrm{Ca}(\mathrm{OH})_{2}+\text { heat } \rightarrow \mathrm{CaO}+\mathrm{H}_{2} \mathrm{O}\left(\text { at } 520^{\circ} \mathrm{C}\right) .
\end{aligned}
$$

Recovery of stored heat:

$$
\begin{aligned}
& \mathrm{MgO}+\mathrm{H}_{2} \mathrm{O} \rightarrow \mathrm{Mg}(\mathrm{OH})_{2}+\text { heat, or } \\
& \mathrm{CaO}+\mathrm{H}_{2} \mathrm{O} \rightarrow \mathrm{Ca}(\mathrm{OH})_{2}+\text { heat. }
\end{aligned}
$$

2. Hiyh erlergy density:

20,000 Btu/ft ${ }^{3}$ in a prastical Eyotcm (theoretical ds hlgh as $90,000 \mathrm{Btu} / \mathrm{ft}^{3}$ ).

3. Need for high absorber temperatures:

$\sim 400^{\circ} \mathrm{C}$ aud hilgher.

4. Unique capabilities:

Long-term storage, no time limit; transportable; stored heat may be delivered at high or low temperatures.

The most valuable feature claimed for this system ${ }^{7}$ ie that the oxides may be stored for indefinite periods at ambient temporature, and hoat can be generaled frum them as required by simply adding water. Both oxides ( $\mathrm{MgO}$ and $\mathrm{CaO}$ ) are relatively inexpensive. Calcium oxide was listed in the Chemical Marketing Reporter for April 14, 1975, as low as one cent per pound. The heats of hydration are of the order of $600 \mathrm{Btu}$ per pound of hydroxide for hydration with water vapor and about one-half to two-thirds that with liquid water. Based on the theoretical density of the hydroxide, the volumetric heat of hydration is $90,000 \mathrm{Btu} / \mathrm{ft}^{3}$, but this value would be reduced to about $20,000 \mathrm{Btu} / \mathrm{ft}^{3}$ in a practical system. 


\subsection{Characteristics of Candidate TES Media}

\subsubsection{Low-temperature TES materials}

Thermal energy storage materials and devices that could be adopted to the storage of solar energy in the low-temperature regime (100 to $250^{\circ} \mathrm{F}$ ) have been adequately tabulated and described in refs. I through 12. Temperatures in this range are applicable for space heating, domestic water heating, single-cycle air conditioning, and organic Rankine-cycle low-temperature turbines. In an ERDA report, ${ }^{8}$ over 50 substances were identified as promising phase-change solar heat storage candidate materials melting in the range 50 to $195^{\circ} \mathrm{F}$, and about 20 of these materials exhibited little or no supercooling and were considered prime candidates for encapsulation studies.

Some of the more promising low-temperature TES materials, other than water, that have properties consistent with the requirements of suitable solar TES media, are listed in Tables 4.1, 4.2, and 4.3.

Table 4.1. Candidate thermal energy storage materials without phase change

\begin{tabular}{|c|c|c|c|c|c|}
\hline \multirow[b]{2}{*}{ Material } & \multirow{2}{*}{$\begin{array}{l}\text { Density } \\
\left(1 \mathrm{~b} / \mathrm{ft}^{3}\right)\end{array}$} & \multicolumn{2}{|c|}{$\begin{array}{l}\text { Sensible heat storage } \\
\text { between } 77 \text { and } 900^{\circ} \mathrm{F}\end{array}$} & \multirow{2}{*}{$\begin{array}{l}\text { Price } \\
(\$ / 100 \text { 1b })\end{array}$} & \multirow{2}{*}{$\begin{array}{l}\text { Output } \\
\text { (Btu/s) }\end{array}$} \\
\hline & & $\mathrm{Btu} / \mathrm{lb}$ & $\mathrm{Btu} / \mathrm{ft}^{3}$ & & \\
\hline$A l$ & 168. & 200 & 34,000 & 29.00 & 690 \\
\hline $\mathrm{Al}_{2}\left(\mathrm{SO}_{4}\right)_{3}$ & 169 & 202 & 34,000 & 3.11 & 6,500 \\
\hline $\mathrm{Al}_{2} \mathrm{O}_{3}$ & 250 & 200 & 50,000 & 2.20 & 9,100 \\
\hline $\mathrm{CaCl}_{2}$ & 135 & 135 & 18,000 & 2.20 & 6,000 \\
\hline $\mathrm{MgO}^{-2}$ & 223 & 208 & 46,000 & 2.80 & 7,400 \\
\hline $\mathrm{KCl}$ & 124 & 140 & 17,400 & 1.65 & 8,500 \\
\hline $\mathrm{K}_{2} \mathrm{SO}_{4}$ & 167 & 180 & 30,000 & 1.10 & 16,400 \\
\hline $\mathrm{Na}_{2} \mathrm{CO}_{3}$ & 160 & 265 & 42,500 & 4.00 & 6,600 \\
\hline $\mathrm{NaCl}$ & 136 & 180 & 24,500 & 1.33 & $13 ; 5 \cap 0$ \\
\hline $\mathrm{Na}_{2} \mathrm{SO}_{4}$ & 168 & 247 & 41,500 & 1.50 & 16,400 \\
\hline Cast iron & 484 & 102 & 49,500 & 10.00 & 1,000 \\
\hline Rocks & 140 & 160 & 22,500 & 1.00 & 16,000 \\
\hline
\end{tabular}

Source: M. Altman et al., Conservation and Better Utilization of Electric Power by Means of Thermal Energy Storage and Solar Heating, Phase I Summary Report, NSF/GI27976, University of Pennsylvania National Center for Energy Management and Power (Oct. 1, 1971), pp. 2-10.- 
Table 4.2. Inorganic salt hydrate TES materials with melting points appropriate fcr space heating applications

\begin{tabular}{|c|c|c|c|c|c|c|c|}
\hline \multirow[b]{2}{*}{ Salt hydrate } & \multirow[b]{2}{*}{$\operatorname{Ref}$} & \multirow{2}{*}{$\begin{array}{l}\text { Melting } \\
\text { point }\left({ }^{\circ} \mathrm{F}\right)\end{array}$} & \multicolumn{2}{|c|}{$\begin{array}{c}\text { Specific heat } \\
\left(\text { Btu } 1 b^{-1}{ }^{\circ} F^{-1}\right) \\
\end{array}$} & \multirow{2}{*}{$\begin{array}{l}\text { Density } \\
\left(1 \mathrm{~b} / \mathrm{ft}^{3}\right)\end{array}$} & \multicolumn{2}{|c|}{ Heat of fusion } \\
\hline & & & Solid & Liquid & & $\overline{B t u / 1 b}$ & $\mathrm{Btu} / 1 \mathrm{~b}^{3}$ \\
\hline $\mathrm{CaCl}_{\bar{z}} \cdot 6 \mathrm{H}_{2} \mathrm{O}$ & 2,4 & 86 & 0.35 & 0.35 & 102 & 75 & 7,650 \\
\hline $\mathrm{Ca}\left(\mathrm{NO}_{3}\right)_{2} \cdot 4 \mathrm{H}_{2} \mathrm{O}$ & 4,5 & 117 & 0.35 & 0.58 & 116 & 66 & 7,656 \\
\hline $\mathrm{Na}_{2} \mathrm{HPO}_{4} \cdot 12 \mathrm{H}_{2} \mathrm{O}$ & 2,4 & 96 & 0.37 & 0.76 & 95 & 120 & 11,400 \\
\hline $\mathrm{Na}_{2} \mathrm{~S}_{2} \mathrm{O}_{3} \cdot 5 \mathrm{H}_{2} \mathrm{O}$ & 2,4 & 118 & 0.35 & 0.57 & 103 & 90 & 9,270 \\
\hline $\mathrm{Na}_{2} \mathrm{SC}_{4} \cdot 10 \mathrm{H}_{2} \mathrm{O}$ & $2,4,5$ & 90 & 0.42 & 0.79 & 91 & 108 & 9,828 \\
\hline $\mathrm{Na}_{2} \mathrm{CC}_{3} \cdot 10 \mathrm{H}_{2} \mathrm{O}$ & 2,5 & 93 & 0.45 & 0.80 & 90 & 108 & 9,720 \\
\hline $\mathrm{Na}_{2} \mathrm{CC}_{3} \cdot 12 \mathrm{H}_{2} \mathrm{O}$ & 5 & 97 & $0.47^{a}$ & $0.84^{a}$ & 95 & 114 & 10,830 \\
\hline $\mathrm{Zn}\left(\mathrm{NC}_{3}\right)_{2} \cdot 4 \mathrm{H}_{2} \mathrm{O}$ & 2,4 & 118 & 0.32 & 0.54 & 129 & 72 & 9,288 \\
\hline $\mathrm{FeCl}_{3} \cdot 6 \mathrm{H}_{2} \mathrm{O}$ & 2,5 & 97 & 0.32 & 0.46 & 101 & 96 & 9,696 \\
\hline
\end{tabular}

$a_{\text {Estimated. }}$ 
Table 4.3. Calorimetric and financial data for organic TES materials for solar heating

\begin{tabular}{|c|c|c|c|c|c|c|c|}
\hline \multirow[b]{2}{*}{ Materiais } & \multirow[b]{2}{*}{ Supplier } & \multirow{2}{*}{$\begin{array}{l}\text { Temperature } \\
\text { range }\left({ }^{\circ} \mathrm{F}\right)\end{array}$} & \multirow{2}{*}{\multicolumn{2}{|c|}{$\frac{\text { Heat of fus } 1 \text { son }^{a}}{B(u) / b}$}} & \multicolumn{2}{|c|}{ Estimated cost } & \multirow{2}{*}{$\begin{array}{c}\text { Heat atorage } \\
\text { density }\left(B \mathrm{Bru} / \mathrm{ft}^{3}\right)\end{array}$} \\
\hline & & & & & \$/1b & $\$ / 1000 \mathrm{BEU}$ & \\
\hline Art1fictal spermacet 1 & Lipo Chemisals & $95-118$ & 47 & 84 & $0.60^{b}$ & 7.15 & 5000 \\
\hline Artificlal spermacet 1 & L1po Chemizals & $104-118$ & 32 & 32 & $0.60^{b}$ & 18.80 & 3400 \\
\hline $\begin{array}{l}\text { Paraffin wax }+ \\
25 \text { we } z \mathrm{CCl}_{4}\end{array}$ & Arthur $\mathrm{K}$. Thomas & $104-122$ & 23 & 41 & 0.085 & 2.07 & 2400 \\
\hline $\begin{array}{l}\text { Parraffin wax }+ \\
33 \text { we } \approx \mathrm{CCl}_{4}\end{array}$ & Arthur H. Thomas & $104-118$ & 25 & 45 & 0.095 & 2.11 & 2500 \\
\hline 8116 Paraffin wax & Sun $011 \mathrm{Ca}$. & $114-116$ & 50 & 90 & 0.065 & 0.72 & 4400 \\
\hline
\end{tabular}

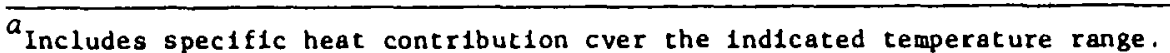

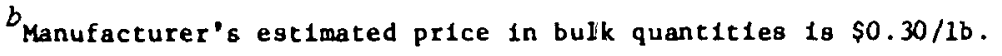

Source: H. Lorsch et al., Conservation and Better Utilization of Electric Power by Means of Thermal Storage and Solar Heating, Final Summary Report, NSF/RANN/SE/GI27976/PR/73/5, University of Pennsy1vania National Center for Energy Management and Power, July 31, 1973, Table 6-13, p. 6-45. 
Water as a sensible heat storage material. In the Proceedings of the Workshop on Solar Energy Storage Subsystems for the Heating and Cooling of Buildings, 1 it was concluded that, in comparison with the other alternatives currently available, water in the temperature range 140 to $180^{\circ} \mathrm{F}$ for space heating and domestic water heating is probably the best and the least expensive mode of storage currently available.

Water is available in practically unlimited quantities and possesses an extraordinary ability to collect and store large quantities of thermal energy. The high specific heat of water, combined with its relatively high density, results in the largest values of $\rho C_{p}$ (volumetric heat capacity) known in nature. The thermodynamic properties of water pertinent to use as a TES materials are shown in Figs. 4.1 through 4.3.3 Figure 4.1 shnws the density of water; and Figs. 4.2 and 4.3 show, respectively, the specific heat and the incressed lieat accumulation capacity of water with increasing temperature.

Freezing of water in TES units for solar heating systems is easily prevented by mixing with ethylene glycol. 5 This material costs $\$ 0.78 /$ gal in bulk-(1971 dollars). A 1:I mixture of water and ethylene glycol has a-freezing temperature of $-35^{\circ} \mathrm{F}$, which is safe for $+10^{\circ} \mathrm{F}$ ambient air temperature, assuming $25^{\circ} \mathrm{F}$ radiant cooling against a clear, cold, night sky. However, this reduces the specific heat of the medium from 1.0 to $0.81 \mathrm{Btu} 1 \mathrm{~b}^{-1}{ }^{\circ} \mathrm{F}^{-1}$.

As the temperature increases above about $350^{\circ} \mathrm{F}$, the vapor pressure of water increases rapidly; and the problems of structural integrity for processing equipment also become increasingly severe.

Sensible heat storage materials other than water. Table 4.1 lists some candidate sensible heat TES materials other than water that are commerclally available in large quantities and are relatively inexpensive. The heat content of these materials corresponds to a temperature range 77 to $900^{\circ} \mathrm{F}$.

Phase-change materials properties. Properties of some alternative inorganic salt hydrate TES materials with melting points appropriate for space heating applications are given in Table $4.2 .5,9,12$ Table 4.3 presents calorimetric and financial data for some organic TES material that could be used for solar heat storage.5

\subsubsection{Intermediate-temperature TES media}

At processing temperatures above $350^{\circ} \mathrm{F}$ but less than $750^{\circ} \mathrm{F}$. the heat transfer agents most commonly used are petroleum-derived heat transfer oils. ${ }^{3}$ Some synthesized organic fluids can extend this range to well above the critical temperature of water $\left(705.34^{\circ} \mathrm{F}\right)$, and siliconcontaining compounds have been used up to a limit of about $800^{\circ} \mathrm{F} .14$ Certain of these heat transfer agents are proposed as thermal energy storage media to provide the intermediate temperature source for dualcycle air conditioners and low-temperature turbines (in the temperature 


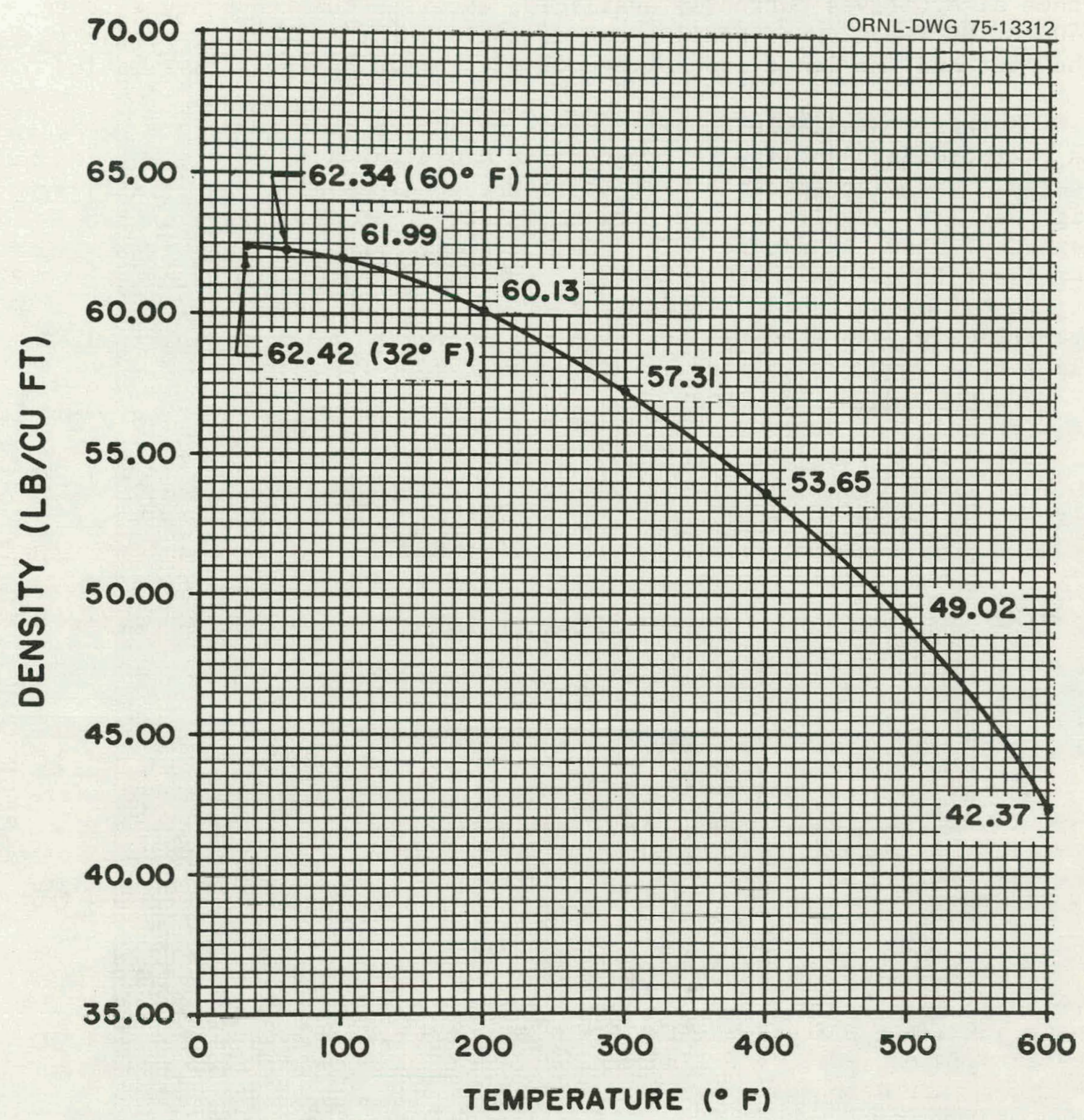

Fig. 4.1. Density of water vs temperature. Source: By permission from Van Nostrand Reinhold Company, New York. From P. L. Geiringer, Handbook of Heat Transfer Media, 1962, Fig. L-1.1, p. 105. 


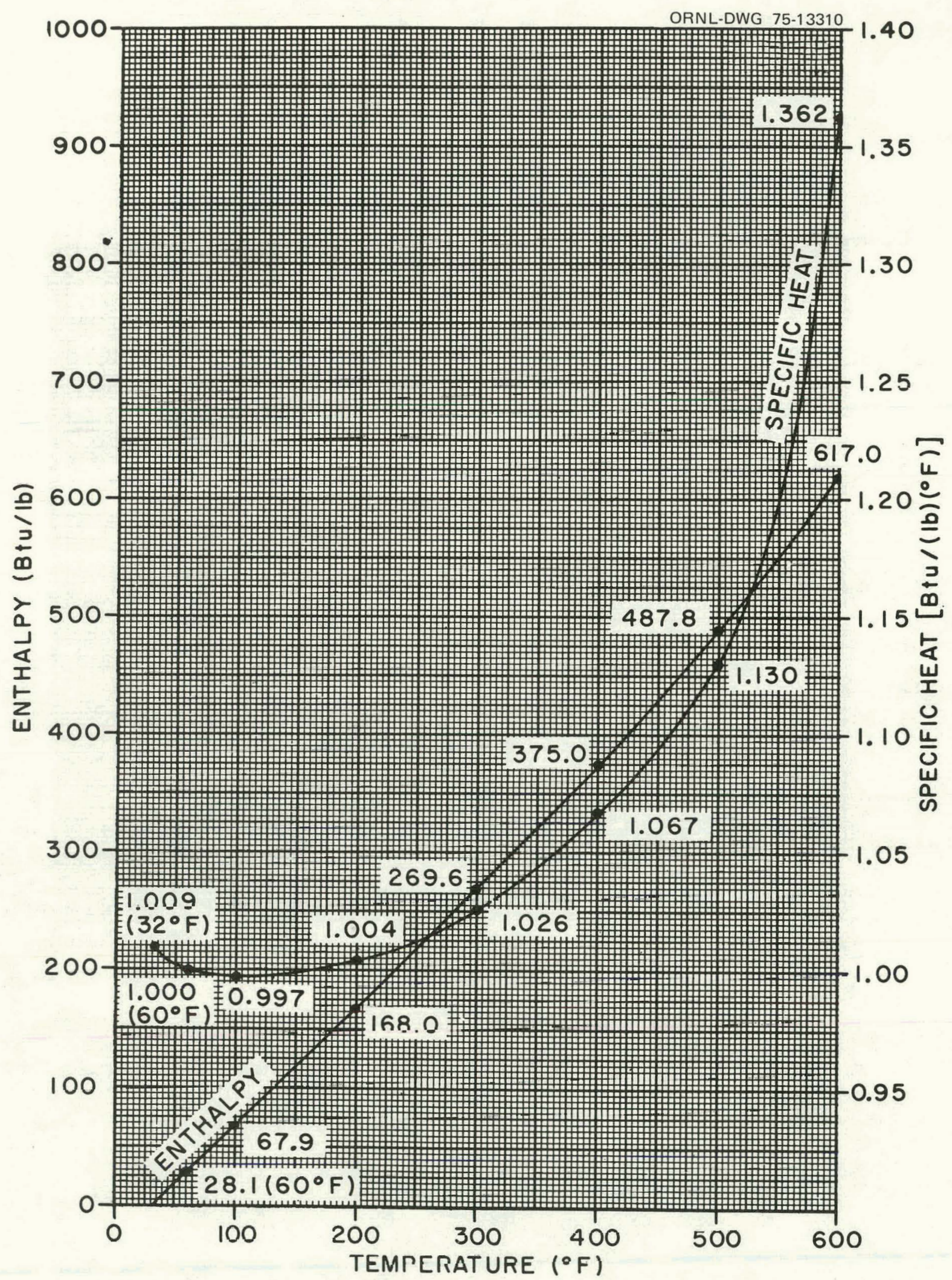

Fig. 4.2. Enthalpy and specific heat of water vs temperature. (Note: Enthalpy values assigned with respect to zero enthalpy for saturated water at $32^{\circ} \mathrm{F}$.) Source: By permission from Van Nostrand Reinhold Company, New York. From P. L. Geiringer, Handbook of Heat Transfer Media, 1962, Fig. L-1.2, p. 106. 


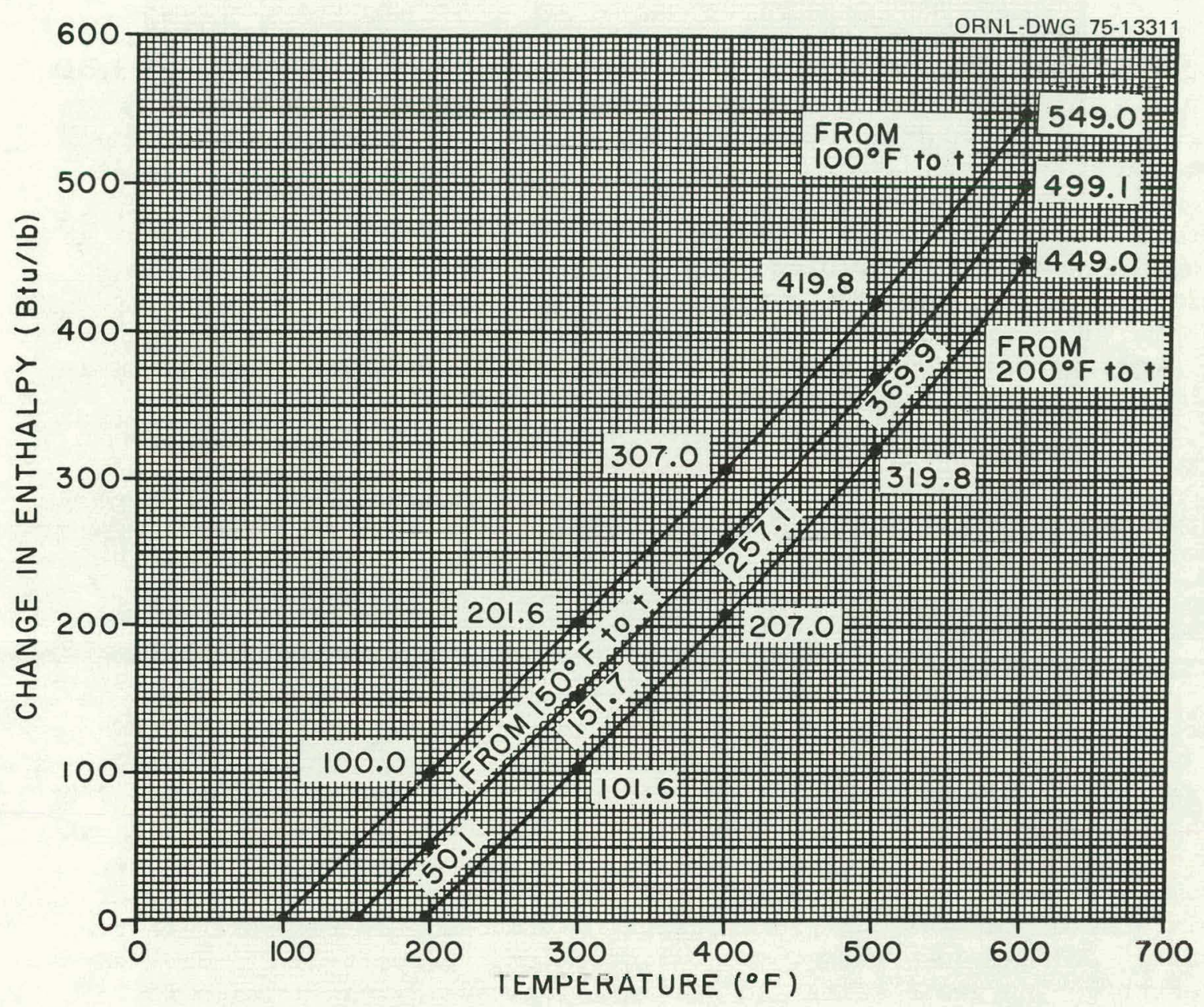

Fig. 4.3. Change in enthalpy of water vs temperature. Source: By permission from Van Nostrand Reinhold Company, New York. From P. L. Geiringer, Handbook of Heat Transfer Media, 1962, Fig. L-1.3, p. 107. 
range 300 to $400^{\circ} \mathrm{F}$ ) and for driving Rankine-cycle turbines using fluids from parabolic-trough collectors in the temperature range 400 to $600^{\circ} \mathrm{F}$. In addition to the above organic agents, mixtures of inorganic salts in the melt state have demonstrated relatively high coefficients of heat transfer and good stability and have been used for heat transfer agents from about 500 to $750^{\circ} \mathrm{F}$. Some of these inorganic salt mixtures are proposed as TES materials in the intermediate-temperature regime.

The physical and thermal characteristics of some frequently used organic heat transfer agents being considered for thermal storage media in the intermediate-temperature regime are given in Table 4.4. These media could be used to store thermal energy as sensible heat in nonpressurized containers up to the maximum usable temperature range. However, the organic fluids are flammable, provided the fluid is at sufficiently high temperature and a snurce of ignition is present. At the flash point, the fluids will momentarily ignite on application of a flame or spark; and al Llie flre point, vapor is emitted at a rate adequate to sustain combustion. At the autoignition temperature, no source of ignition is required, but typically this temperature is well above the fluid's recommended range.

Table 4.5 (from ref. 12) lists the physical properties of some inorganic salt mixtures that could be used as thermal energy storage media for intermediate-temperature-range applications.

\subsubsection{Representative high-temperature TES media}

Thermal energy storage temperatures in the range 800 to $1000^{\circ} \mathrm{F}$ are proposed for closed-cycle gas turbine and steam Rankine-cycle turbine applications using fluids from heliostats. At temperatures in excess of Llie upper limic of the organic heat transfer fluids (approximately $750^{\circ} \mathrm{F}$ ), Lliese fluids tend to decompose; also, a hazardous condition is presented by operation approaching their flammability temperature. Therefore, for temperatures above the operating 1 imits of the organic heat transfes vils, mixtures of various inorganic salts are proposed for the solar thermal energy storage subsystems. Pertinent thermal properties of some representative inorganic salts and salt mixtures are given in Table 4.6.16

The materials listed in Table 4.6 hy $n$ means exhaust the number of potential inorganic salts suitable for high-temperature application. They are, however, representative of this class of material. A survcy of high-temperature thermal energy storage techniques for solar-thermal applications is Lu be published by the Solar Energy Technology Division of Sandia Laboratories in the near future. 15 These data, however, are not available for reference in this report.

Table 4.7 (from ref. 12) lists several inexpensive relatively abundant thermal energy storage phase-change materials with melting points below $1000^{\circ} \mathrm{F}$. 
Table 4.4. Frequently used organic heat transfer agents

\begin{tabular}{|c|c|c|c|c|c|c|c|c|c|c|c|}
\hline \multirow{3}{*}{ Trade name } & \multirow{3}{*}{ Composition } & \multirow{3}{*}{ Producer } & \multirow{2}{*}{\multicolumn{2}{|c|}{$\begin{array}{c}\text { UE able temperature range } \\
\left({ }^{\circ} \mathrm{F}\right)\end{array}$}} & \multirow{3}{*}{$\begin{array}{l}\text { Pire } \\
\text { poolnt } \\
\left({ }^{\circ} \mathrm{P}\right)\end{array}$} & \multirow{3}{*}{$\begin{array}{c}\text { Auto- } \\
\text { 1gnition } \\
\text { temperature } \\
\left({ }^{\circ} P\right)\end{array}$} & \multicolumn{4}{|c|}{ Thermal propertiea at maximum usable temperature } & \multirow{3}{*}{ Coumen:s } \\
\hline & & & & & & & \multirow{2}{*}{$\begin{array}{c}\text { Spec1fic } \\
\text { heat } \\
\left(\text { Btu } 1 b^{-1}{ }^{\circ} F^{-1}\right)\end{array}$} & \multirow{2}{*}{$\begin{array}{c}\text { Viscosity } \\
\left(1 \mathrm{f} \mathrm{ft}^{-1} \mathrm{hr}^{-1}\right)\end{array}$} & \multirow{2}{*}{ 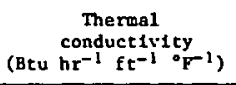 } & \multirow{2}{*}{$\begin{array}{l}\text { Density } \\
\left(1 \mathrm{~b} / \mathrm{ft} \mathrm{t}^{3}\right)\end{array}$} & \\
\hline & & & Low & Maximum & & & & & & & \\
\hline Theraino1-55 & Alky lated ar omatic & Monsanto & - & 600 & 410 & 670 & 0.72 & 1.1 & 0.065 & $45^{\prime}$ & $\begin{array}{l}\text { Currently in use; } \\
\text { requires nonoxidizing } \\
\text { cover gas }\end{array}$ \\
\hline Thernino1-66 & $\begin{array}{l}\text { Kydrogenated } \\
\text { terpheny ls. }\end{array}$ & Monsanto & 2.5 & 650 & 380 & 705 & 0.655 & 0.649 & 0.0612 & 46.8 & $\begin{array}{l}\text { Currently in use; } \\
\text { requires non jxidizing } \\
\text { cover gas }\end{array}$ \\
\hline Cald $=: \mathrm{A}-\mathrm{HT}-43$ & & Exxon & & 600 & & 759 & $:$ & & & & $\begin{array}{l}\text { Currently ln. use; } \\
\text { requires nonjxidizing } \\
\text { cover gas }\end{array}$ \\
\hline Dowtiserm-A & $\begin{array}{l}\text { Dipheny 1-dipheny } 1 \\
\text { oxide eutectic }\end{array}$ & Dow Chemical & 12 & 500 & 275 & 1,150 & 0.537 & 0.65 & 0.0645 & 53.0 & $\begin{array}{l}\text { Requires pressurization } \\
\text { for temperatures } \\
\text { exceed Ing } 500^{\circ} \mathrm{F}\end{array}$ \\
\hline Humbletherw 500 & Aliphat1c petroleum ofl & Humble oil & -5 & 600 & 475 & NA & 0.7165 & 1.01 & 0.0655 & 41.3 & \\
\hline
\end{tabular}


Table 4.5. Thermal storage materials with phase change

\begin{tabular}{|c|c|c|c|c|c|}
\hline \multirow[b]{2}{*}{ Material } & \multicolumn{2}{|c|}{ Density $\left(1 \mathrm{~b} / \mathrm{ft} \mathrm{t}^{3}\right)$} & \multicolumn{2}{|c|}{ Heat content ${ }^{a}$} & \multirow{2}{*}{$\begin{array}{l}\text { Melting } \\
\text { point }\left({ }^{\circ} \mathrm{F}\right)\end{array}$} \\
\hline & Solid & Liquid & Btu/Ib & $\mathrm{Btu} / \mathrm{ft}^{3}$ & \\
\hline $\mathrm{NaOH}$ & 134 & 111 & 510 & 56,500 & 608 \\
\hline $\mathrm{NaNO}_{3}$ & 141 & 119 & 310 & 37,000 & 590 \\
\hline $\mathrm{KCl}+\mathrm{MgCl}_{2}$ & 135 & 110 & 310 & 34,000 & 908 \\
\hline $\mathrm{NaCl}+\mathrm{MgCl}_{2}$ & 135 & 110 & 320 & 35,000 & 806 \\
\hline $\mathrm{B}_{2} \mathrm{O}_{3}$ & 115 & 102 & 400 & 40,500 & 842 \\
\hline
\end{tabular}

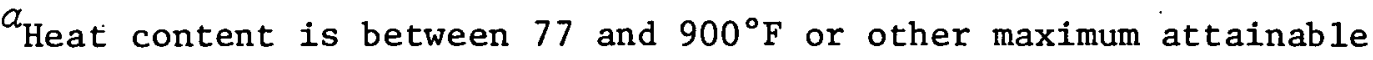
temperature.

Source: M. Altman et al., Conservation and Better Utilization of Electric Power by Means of Thermal Energy Storage and Solar Heating, Phase I Summary Report, NSF/GI27976, University of Pennsylvania National Center for Energy Management and Power, Oct. 1, 1971, Table 4, p. 2-14.

Tahle 4.6. Thermal propertiec of roprcocntative inorgaili sall TEs walerlals

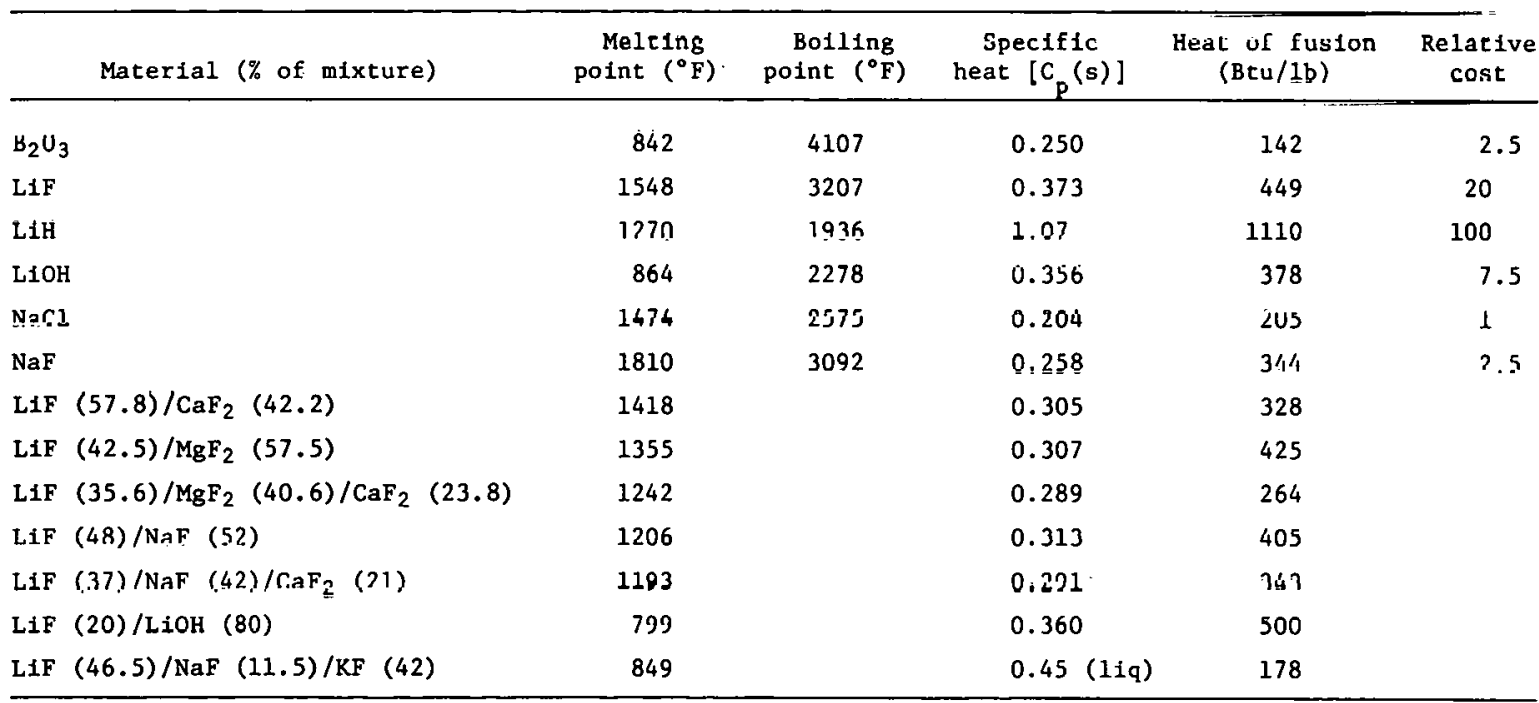

Source: T. T. Bramlette et al., Sumey of high Temperature Thermal Eneray Storage Techniques for Solar Thermal Applications, SAND 75-8063, Sandia Laboratories, Livermore, Calif. (1976). 
Table 4.7. Thermal storage materials with phase change

(Heat content is between $77^{\circ}$ and $900^{\circ} \mathrm{F}$ or other maximum attainable temperature.)

\begin{tabular}{|c|c|c|c|c|c|c|c|c|}
\hline Material & $\frac{\text { Density }}{\text { Solid }}$ & $\frac{\left(1 b / f t^{3}\right)}{\text { Licuid }}$ & $\begin{array}{r}\text { Heat } \\
\text { to } \\
\text { Btu/1b }\end{array}$ & $\begin{array}{l}\text { content } \\
900^{\circ} \mathrm{F} \\
\mathrm{Btu} / \mathrm{ft}\end{array}$ & $\begin{array}{l}\text { Melting } \\
\text { point }{ }^{\circ} \mathrm{F}\end{array}$ & $\begin{array}{c}\text { Price } \\
(\$ / 1001 b)\end{array}$ & $\mathrm{Btu} / \$$ & Remarks \\
\hline $\mathrm{NaOH}$ & 134 & 111 & 510 & 56,500 & 608 & 7.00 & 7,300 & $\begin{array}{l}\text { Caustic } \\
\text { soda }\end{array}$ \\
\hline $\mathrm{NaNO}_{3}$ & 141 & 119 & 310 & 37,000 & 590 & 2.60 & 12,000 & $\begin{array}{l}\text { Decomp. at } \\
700^{\circ} \mathrm{F}\end{array}$ \\
\hline $\mathrm{KCl}+\mathrm{MgCl}_{2}$ & 135 & $\Xi 10$ & 310 & 34,000 & 908 & 2.40 & 12,800 & To $910^{\circ} \mathrm{F}$ \\
\hline $\mathrm{NaCl}+\mathrm{MgCl}_{2}$ & 135 & 110 & 320 & 35,000 & 806 & 2.40 & 13,200 & \\
\hline
\end{tabular}




\section{REFERENCES FOR SECTION 4}

1. C. L. Segaser, MIUS Technology Evaluation - Thermal Energy Storage Materials and Devices, ORNL/HUD/MIUS-23 (August 1975).

2. J. I. Yellot, "Utilization of Sun and Sky Radiation for Heating and Cooling of Buildings," ASHRAE J. 15(12): 31-42 (December 1973).

3. P. L. Geiringer, Handbook of Heat Transfer Media, Reinhold Publishing Corp., New York, 1962.

4. D. V. Hale et al., Phase Change Materials Handbook, NASA-CR-61363, Lockheed Missiles and Space Co., September 1971.

5. H. Lorsch (ed.), Conservation and Better Utilization of Electric Puwe' by Means of I'hermal t'nergy S'torage and Solar Heating, Final Summary Report, NSF/RANN/SE/GI27976/TR/73/5, University of Pennsylvania National Center for Energy Management and Power (July 31, 1973).

6. G. G. Libowitz, "Metal Hydrides for Thermal Energy Storage," pp. 322-25 in Proc. 9th Intersoc. Energy Convers. Eng. Conf., American Society of Mechanical Engineers, New York, 1974.

7. G. Ervin, "Solar Heat Sturage Based on Inorganic Chemical Reactions," pp. 91-99 in Proceedings of the Workshop on Solar Energy Storage Subsystems for the Heating and Cooling of Buildings, NSF-RANN-75-041, American Society of Hoating, Refrigerating, and Air Cundtioning Engineers, 1975.

8. G. A. Lane et a1., Solar Energy Subsystems Employing Isothermat. Heat Storage Materials, ERDA-117, Phase I Technical Report (May 1975).

9. H. G. Lorsch, Latent Heat and Sensible Heat Storage for Solar Heating Systems, NSF/RANN/SE/GI27976/TR/72/20, University of Pennsylvania National Center for Energy Management and Power (May 1974).

10. M. Telkes, "Thermal Storage for Solar Heating and Cooling," pp. 17-23 in Proceedings of the Workshop on Solar Energy Storage Subsystems for the Heating and Cooling of Buildings, NSF-RANN-75-041, American Society of Heating, Refrigerating, and Air Conditioning Engineers, 1973 .

11. G. C. Szego, "Hot Water Storage Systems Group Report," pp. 165-66 in Proceedings of the Workshop on Solar Energy Storage Subsystems for the Heating and Cooling of Buildings, NSF-RANN-75-041, American Society of Heating, Refrigerating, and Air Conditioning Engineers, 1975. 
12. M. Altman et al., Conservation and Better Utizization of Electric Power by Means of Thermal Energy Storage and Solar Heating, Phase I Summary Report, NSF/GI27976, University of Pennsylvania Nationa1 Center for Energy Management and Power (Oct. 1, 1971).

13. W. F. Seifert and L. L. Jackson, "Organic Fluids for High-Temperature Heat Transfer Systems," Chemical Engineering 79(24): 96-104 (Oct. 30, 1972).

14. J. R. Fried, "Heat Transfer Agents for High-Temperature Systems," Chemical Engineering 80(12): 89-98 (May 28, 1973).

15. T. T. Bramlette et al., Survey of High Temperature Thermal Energy Storage Techniques for Solar Thermal Applications, SAND 75-8063, Sandia Laboratories, Livermore, Calif. (1976).

16. J. R. Kettler, "The Thermal Vehicle - A Pollution-Free Concept," Paper 759084, pp. 548-54 in Proc. 10th Intersoc. Energy Convers. Eng. Conf., Institute of Electrical and Electronics Engineers, Inc., New York (August 1975). 


\section{SELECTED CANDIDATE SOLAR ENERGY STORAGE SUBSYSTEMS}

\subsection{Selection Criteria}

Although the selection of candidate solar energy storage materials will primarily be based on the materials' heat storage capabilities in the desired temperature range, other considerations will considerably influence the final choice. The engineering feasibility of the candidate TES subsystem in the near future (1975 to 1985) must be considered, as well as the amount of detail currently available on the cost and performance characteristics of the candidate system.

In order to select appropriate candidate TES walerlals, the following criteria are suggested: ${ }^{1}$

1. A melting point of PCM materint within the dosirod tomperature range.

2. A high heat of fusion. This property defines the available stored energy and is of importance on a weight or volume basis. The heat of fusion of water ( $80 \mathrm{cal} / \mathrm{g}$ or $144 \mathrm{Btu} / \mathrm{lb}$ ) probably constitutes an upper limit of available TES materials. Other PCM's have heats of fusion ranging from 50 to $75 \%$ of that of water.

3. A congment melting point. Congruent and eutectic salt hydrates are suitable for thermal energy storage because they melt completely at a fixed temperature or within a very narrow range of temperatures. Otherwise, the difference in densities between solid and liquid results in segregation with changes in chemical composition and a reduction in usable latent heat.

4. Dependability of freezing behavior. Upon cooling, the melt should solidify at the thermolynamic melting points otherwise, the 1lquid illay supercool, ultimately forming a glass, and the stored energy will not be released.

5. Long-term reliability during repeated cycling. Materials should be stable and not tend to decompose during the expected lifetime of the equipment ( 10 to 20 years).

6. Compatibility with the container. There is a sufficiently wide choice of potential container materials availablc, includius plastics, aluminum alloys, and ferrous alloys, that this requirement should not constitute a serious limitation.

7. Safety featiures. The TES matcrial should be nonflammable in the desired temperature range, nontoxic, and should not have an offensive odor, since the possibility of accidental leakage always exists.

8. High thermal conductivity. This property is considered desirable to prevent thermal gradients (in PCMs). Fillers are of ten used to improve system performance. 
9. High specific heat and density. These properties are especially important in sensible heat TES material and define the materials' heat storage capability in the same manner as does a high latent heat of fusion for PCMs.

10. Small volume change during phase transition. Most materials shrink when they freeze, and the resultant change in volume varies greatly among PCMs. However, water, gallium, and gallium alloys expand on freezing.

11. Low vapor pressure. Some materials have high vapor pressures near their melting points, thereby exerting excessive stress on their containers.

The solar thermal-electric conversion systems needed to provide the domestic electric load, domestic water heating load, and the spaceheating and-cooling load for these categories of load types in the prescribed temperature regimes will require solar energy storage subsystems capable of storing from 60 to $36 \times 10^{5} \mathrm{kWhr}\left(2.05 \times 10^{5}\right.$ to $1.23 \times 10^{10} \mathrm{Btu}$ ) of thermal energy. ${ }^{2}$ Some specific storage subsystems proposed for initial selection in the various temperature regimes are described in the following subsections.

\subsection{Low-Temperature TES Subsystems}

Water is an obvious selection as a heat storage material in the lowtemperature $\left(100\right.$ to $\left.250^{\circ} \mathrm{F}\right)$ regime. As pointed out in ref. 3, water can be stored in a variety of tanks fabricated from various materials, including wood, concrete, fiberglass, steel, and other metals. However, some municipal ordinances require that water heating and storage systems shall comply with the ASME Low Pressure Heating Boiler Code (Sect. IV) if any of the equipment meets any of the following conditions: ${ }^{4}$

1. operating with storage temperatures above $200^{\circ} \mathrm{F}$,

2. with water-containing capacity in excess of $120 \mathrm{gal}$,

3. a heat input of 200,000 Btu or more.

Several hot water storage subsystems suitable for residential solar energy storage up to temperatures of $200^{\circ} \mathrm{F}$ are described in ref. 5 . It was implied in ref. 5 that the concept illustrated by Fig. 5.1 would probably prove to be the most economical for exterior installations. This subsystem consists of a vertical tank that could be fabricated from several alternate materials. The tank would be buried underground to a depth of 10 to $50 \mathrm{ft}$, depending on the tank capacity and size, and would be insulated to inhibit loss of heat energy.

Aside from the question of structural integrity (horizontal tanks must be designed to resist beam bending and buckling action), vertical tanks are considered more efficient for hot water storage because of the stratification that occurs between layers of hot and cold water.6,7 Thermal stratification improves system efficiency by allowing the collector to operate at the minimum temperature. Results of tests on a pilot 
ORNL-OWG 77-19911

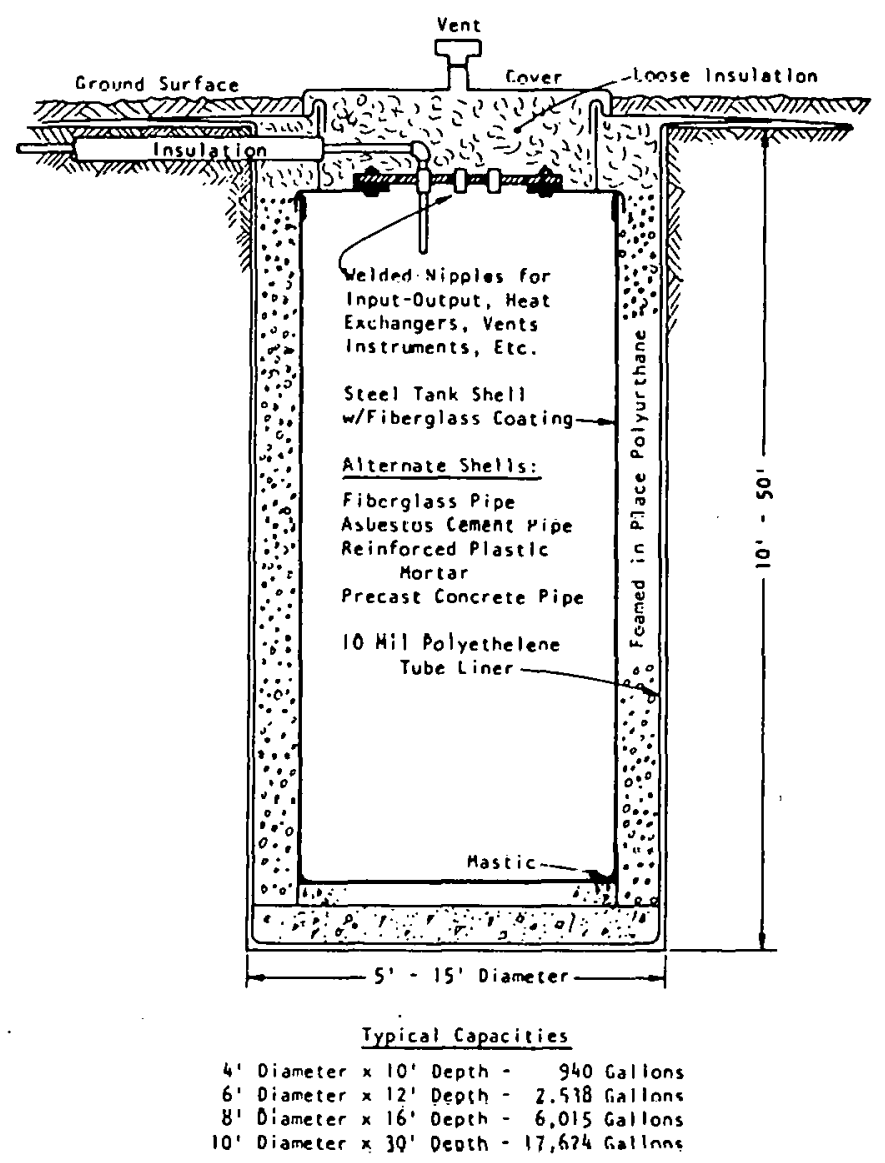

Fig. 5.1. Vertical tank is a drilled hole foamed-in-place insulation (for cohesive soils only). Source: E. E. Pickering, "Residential Hot Water Solar Energy Storage," pp. 24-37 in Proceedings of the Workshow" on Solar Energy Storage Suhsustems for the heating and Cooling of Buildinys, NSF-RANN-75-041, American Society of Heating, Refrigerating, and Air Conditioning Engineers (April 1975).

plant solar water heater scaled to a ten-unit apartment huilding indicated that internal baffling of the tank would not be necessary to obtain a high degree of density stratification for certain solar water heating systems.

As an alternate heat storage material to water in the low-temperuturc regime, one of the available PCMs could be selected. Several inorganic and organic salts, salt hydrates, and eutectics have been investigated as potential heat storage materials for space and domestic water heating (Sect. 4.2.1). The melting points of these materials, however, are nearer the bottom $\left(<120^{\circ} \mathrm{F}\right)$ of the low-temperature regime. For more efficient operation of an organic Rankine-cycle prime mover, a PCM with a melting point nearer the upper limit of the range should probably be selected. Reference 8 lists about 20 candidate PCMs melting in the range 10 to $90^{\circ} \mathrm{C}$ (50 to $194^{\circ} \mathrm{F}$ ) that exhibited little or no supercooling. Heat of fusion measurements have been made on most of these 20 materials. 
The materials listed in Tables I-IV of ref. 8 were classified according to their assessed suitability for heat storage into three groups: I, "most promising"; II, "promising"; and III, less promising." Assignment was based on consideration of the following criteria: toxicity, corrosivity, flammability, oxidizing capability, availability, and cost. The suitability groups were then used to select material for further consideration, which involved laboratory tests of freezing behavior. Based on these tests, the selected materials were further categorized as:

G - good for general use, little or no suppercooling;

$S$ - good, but supercools, must be seeded; useful in tank system;

$\mathrm{N}$ - not good, not usable.

Table 5.1 lists some materials from ref. 8 that have melting points (transition temperatures) above $75^{\circ} \mathrm{C}\left(167^{\circ} \mathrm{F}\right.$ ) and that are rated as either $G$ or $S$ in groups I or II. Of the seven materials listed in Table 5.1, the heats of fusion of only four have been measured. From these four, $\mathrm{Ba}(\mathrm{OH})_{2} \cdot 8 \mathrm{H}_{2} \mathrm{O}$ appears to have the most desirable characteristics of the PCMs in the low-temperature regime.

\subsection{Intermediate-Temperature TES Subsystems}

One of the commercially available heat transfer oils ${ }^{3}$ listed in Table 4.4 of Sect. 4 is suggested for initial selection as a heat storage material in the intermediate-temperature regime $\left(300\right.$ to $600^{\circ} \mathrm{F}$ ). As can be noted from Table 4.4, the physical properties of these fluids are similar, but none equals the thermal heat storage capability of water. The heat transfer oils, however, can be utilized at temperatures approaching the upper range of the intermediate-temperature class of materials without resorting to pressurized containment.

HITEC, 10 a heat transfer salt developed by Du Pont in the 1930's,. is also suggested for selection as a potential material for solar energy storage in the intermediate-temperature regime. HITEC is a white, granular solid eutectic mixture of inorganic salts which has the following composition:

$\begin{array}{lr}\text { potassium nitrate, } \mathrm{KNO}_{3} & 53 \% \\ \text { sodium nitrite, } \mathrm{NaNO}_{2} & 40 \% \\ \text { sodium nitrate, } \mathrm{NaNO}_{3} & 7 \% \text {. }\end{array}$

The melting point of fresh HITEC is $288^{\circ} \mathrm{F}\left(142^{\circ} \mathrm{C}\right)$. The densitytemperature relationship for molten HITEC is presented in the alignment chart of Fig. 5.2. The total heat content of HITEC over the temperature range 70 to $1100^{\circ} \mathrm{F}$ is shown in Fig. 5.3. The slopes of the total heattemperature lines indicated that the specific heat of solid HITEC is 0.32 and that of the melt is $0.373 \mathrm{cal} \mathrm{g}^{-1}{ }^{\circ} \mathrm{C}^{-1}$ (or Btu $1 \mathrm{~b}^{-1}{ }^{\circ} \mathrm{F}^{-1}$ ). Latent heat of fusion is approximately $20 \mathrm{cal} / \mathrm{g}(35 \mathrm{Btu} / \mathrm{lb})$. Other physical properties of HITEC are reported by Bohlmann.10 
Table 5.1. Phase-change T:S materials in the loN-temperature regime with melting points abcve $75^{\circ} \mathrm{C}\left(157^{\circ} \mathrm{F}\right)$

\begin{tabular}{|c|c|c|c|c|c|c|c|}
\hline \multirow{2}{*}{ TES material } & \multirow{2}{*}{-ass } & \multirow{2}{*}{ Group } & \multirow{2}{*}{$\begin{array}{l}\text { Lab } \\
\text { test }\end{array}$} & \multicolumn{2}{|c|}{$\begin{array}{l}\text { Melting } \\
\text { Foint }\end{array}$} & \multicolumn{2}{|c|}{$\begin{array}{c}\text { Latent heat of } \\
\text { phase change }\end{array}$} \\
\hline & & & & ${ }^{\circ} \mathrm{C}$ & ${ }^{\circ} \mathrm{F}$ & $\mathrm{cal} / \mathrm{g}$ & Btu/1b \\
\hline $\mathrm{Mg}\left(\mathrm{NO}_{3}\right)_{2} \cdot 6 \mathrm{H}_{2} \mathrm{O}$ & Inorganic compound & II & $\mathrm{S}$ & 89 & 192.2 & $\mathrm{NA}$ & NA \\
\hline $\mathrm{BA}(\mathrm{OH})_{2} \cdot 8 \mathrm{H}_{2} \mathrm{O}$ & Enorganic compound & II & G & 82 & 179.6 & 63.5 & 114.3 \\
\hline $\mathrm{NH}_{4} \mathrm{Br}(33.4 \%) / \mathrm{CO}\left(\mathrm{NH}_{2}\right)_{2}$ & -nozganic eutectic & II & G & 76 & 168.8 & NA & NA \\
\hline Acetamide $\left(\mathrm{CH}_{3} \mathrm{CONH}_{2}\right)$ & Organic compcund & I & $\mathrm{S}$ & 82 & 179.2 & NA & NA \\
\hline Naphthalene $\left(\mathrm{C}_{10} \mathrm{H}_{8}\right)$ & Grganic compound & I & G & 33 & 181.4 & 35.3 & 63.5 \\
\hline Propionamide $\left(\mathrm{C}_{2} \mathrm{H}_{5} \mathrm{CONH}_{2}\right)$ & Grganic compound & II & G & 34 & 183.2 & 40.2 & 72.3 \\
\hline
\end{tabular}

NA - not available. 
7

ORNL-DWG 77.19913

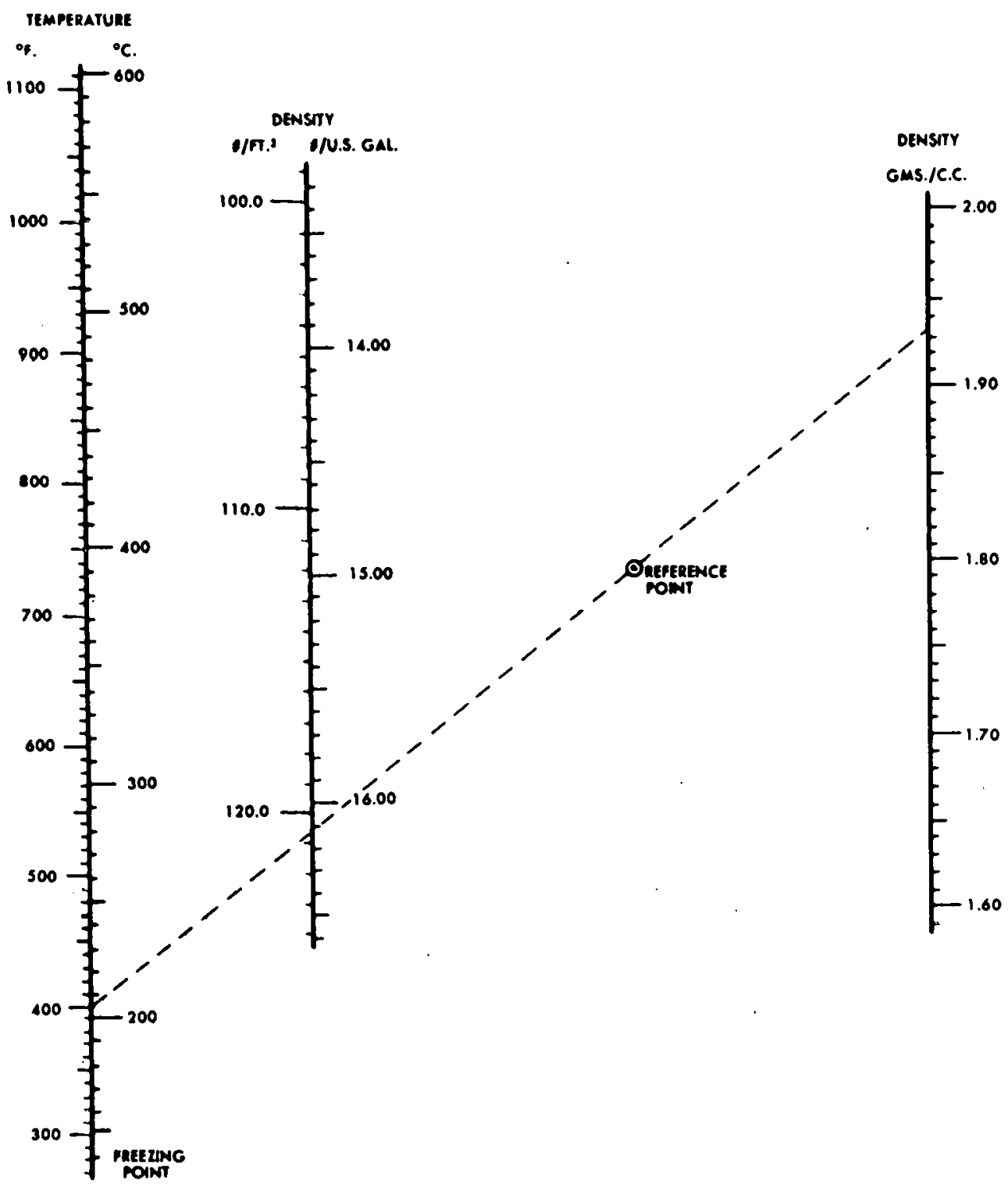

NOTE, TO RND DENSTTY, DRAW A STRAIGMT UME RROM DESIRED POINT ON temrerature scale through the refERENCE pOINT.

Fig. 5.2. Density of liquid HITEC. Source: E. G. Bohlmann, Heat Transfer salt for high-Temperature Steam Generation, ORNL/TM-3777, Oak. Ridge National Laboratory (December 1972), Fig. 7, p. 27. 


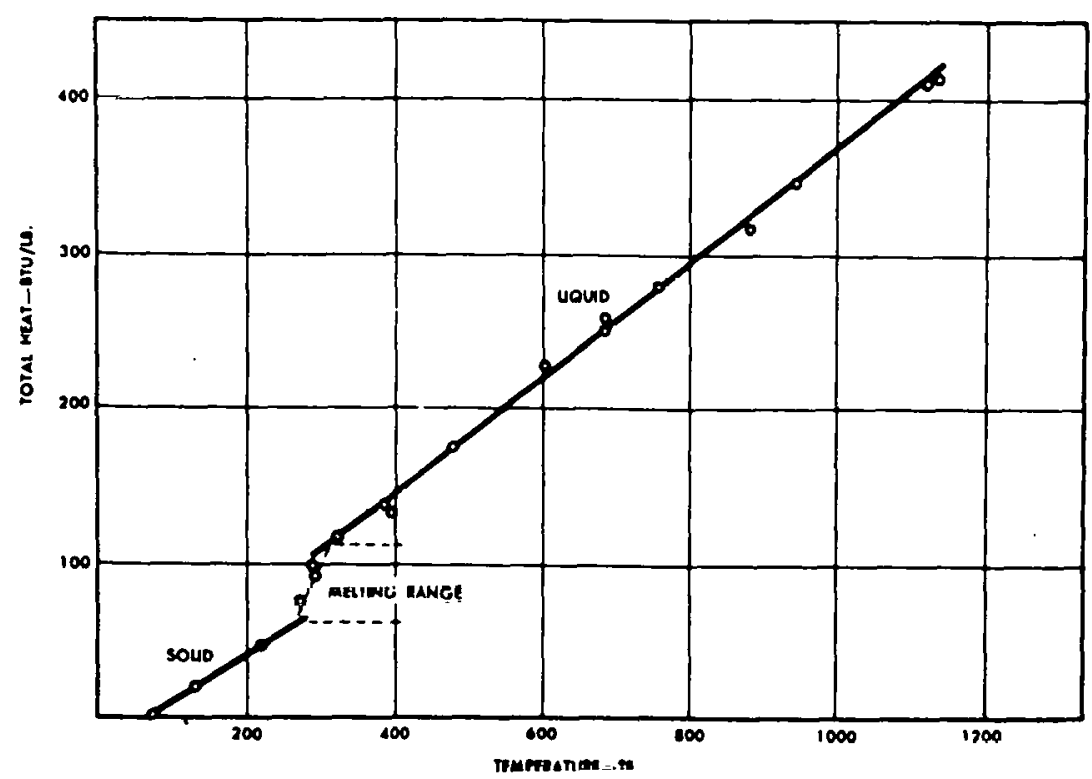

Tig. 5.3. Heat capacity of HITEC. Source: E. G. Bohlmann, heat Transfer Salt for high-Temperature Steam Generation, ORNL/TM-3777, Oak Ridge National Laboratory (December 1972), Fig. 8, p. 30.

An upper limit to the usefi11 nperating tompcrature of IIITEC and other nitrates and nitrites is impnsed hy thermal decomposition. In general, this phenomenon is expected to occur over the temperature range 454 to $538^{\circ} \mathrm{C}\left(849\right.$ to $\left.1000^{\circ} \mathrm{F}\right)$.

Figure 5.4 presellls a comparison of estimated heat storage capabilitles of some selected TES materials usable in the intermediate-temperature regime up to $600^{\circ} \mathrm{F}$. Of the heat transfer nils, raloric HT-13 hao the highest heat storage capability.

- A heat transfer oil such as Caloric HT-43 or a molten salt such as IIITEC call be used in conjunction with a packed bed of solid sensible heat storage material (Table 4.1) such as inexpensive rocks or other compatible material. Since the inexpensive solid material displaces much of the more expensive fluid, such a subsystem is expected to sigulflcancly reduce the cost of an all-fluid sensible heat storage ayotcm. Tigure 5.5 showo a preliminary destgn" concept of a packed-bed heat-transfer-fluid thermal energy storage subsystem that is proposed for the Solar Central Receiver Program.11

*Patent applied for by the McDonnel1-Douglas Astronautics Company and the Rocketdyne Division of Rockwel1 International. 


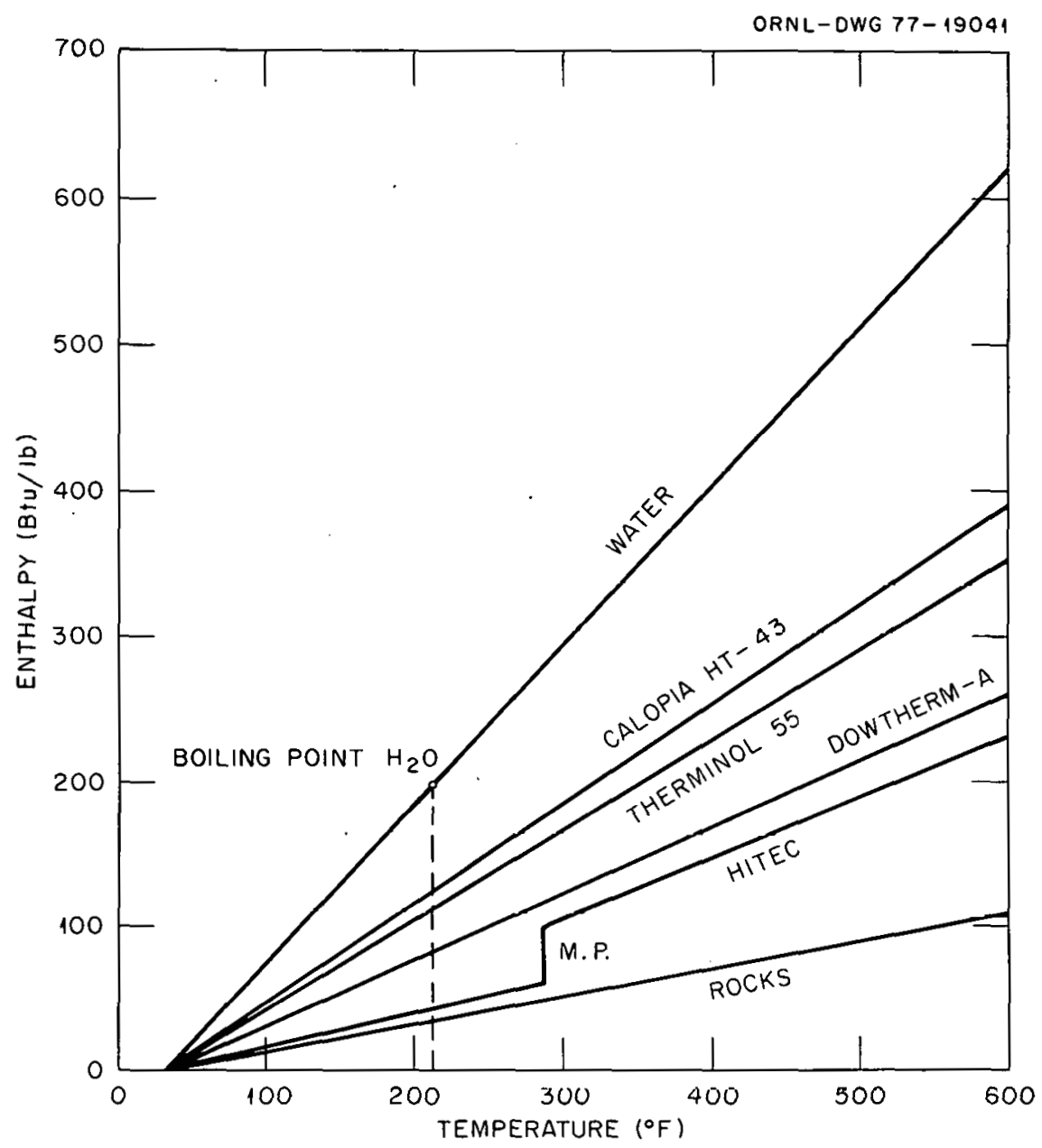

Fig. 5.4. Comparative heat storage capabilities of some selected TES materials.

\subsection{High-Temperature TES Subsystems}

For solar energy conversion applications in the high-temperature $\left(800\right.$ to $1000^{\circ} \mathrm{F}$ ) regime, a PCM utilizing the heat of fusion of an inorganic salt is recommended. A survey of high-temperature thermal energy storage techniques for solar thermal applications has been recently completed by personnel of the Sandia Laboratories in Livermore, California, and a report ${ }^{1}$ describing their work is under preparation.

The thermal properties of several inorganic salt mixtures, that have melting points in or near the high-temperature range and that could be selected for the first-round investigation of appropriate solar energy subsystems are given in Table 5.2. The characteristics of these materials 
ORNL-DWG 77.19916

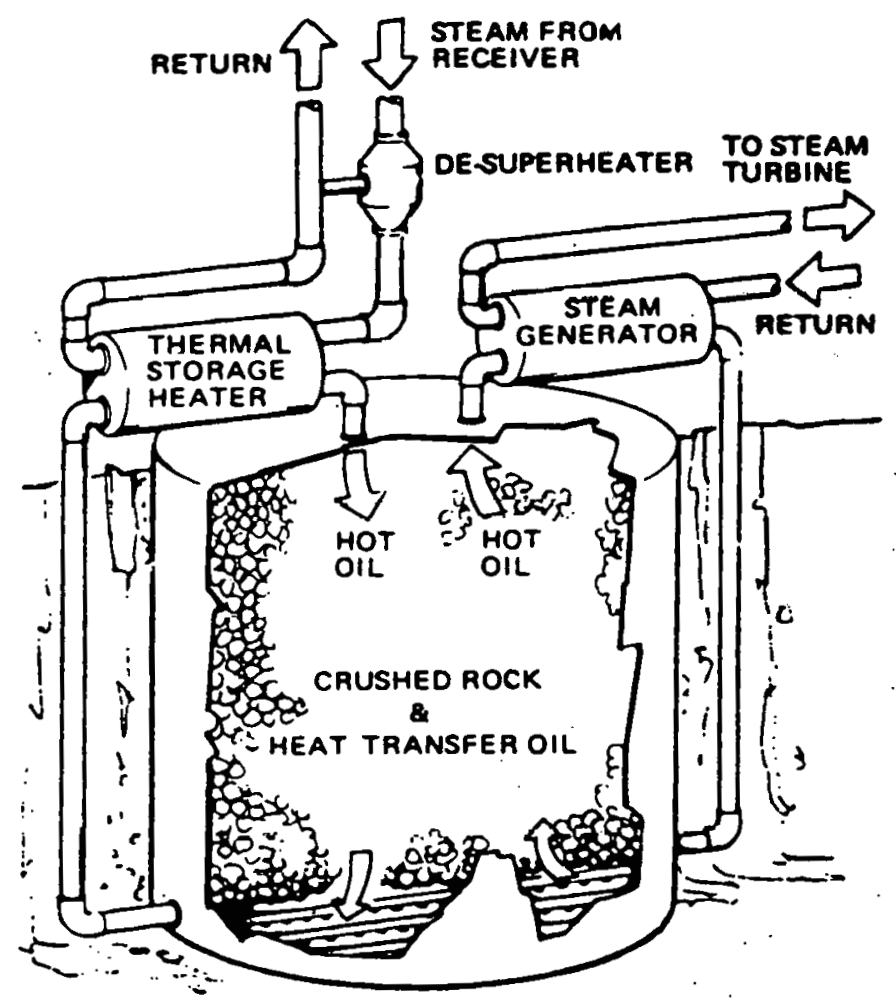

Fig. 5.5. Packed-bed heat-transfer-fluid thermal energy storage subsystem. Source: T. T. Bramlettp et al., Survoy of liqgit Temilutulure Thermal Energy Storage, SAND 75-8063, (Mar. 1976).

Table 5.2. Therma1 propertiec of aeveral litgh-tcmperature inorganic salt mixtures

\begin{tabular}{|c|c|c|c|c|c|}
\hline \multirow{2}{*}{ Material } & \multirow{2}{*}{$\begin{array}{l}\text { Melting } \\
\text { point } \\
\left({ }^{\circ} \mathrm{H}^{\prime}\right)\end{array}$} & \multirow{2}{*}{$\begin{array}{l}\text { Heat of } \\
\text { fusion } \\
(\mathrm{B} \in \mathrm{u} / \mathrm{lb})\end{array}$} & \multicolumn{2}{|c|}{ Density $\left(1 \mathrm{~b} / \mathrm{ft} \mathrm{t}^{3}\right)$} & \multirow{2}{*}{$\begin{array}{l}\text { Specific heat } \\
\left.\text { (btu } 1 b^{-1}{ }^{u} F^{-1}\right)\end{array}$} \\
\hline & & & Sest 1,1 & Liquid & \\
\hline $\mathrm{NaOH}$ & 608 & 1.36 .8 & 134 & 111 & 0.50 \\
\hline $\mathrm{NaNO}_{3}$ & .509 & 73.8 & 141 & 119 & 0.44 \\
\hline $\mathrm{NaCl}+\mathrm{MgCl}_{2}$ & 806 & $138 . \overline{5}$ & 135 & 110 & 0.26 \\
\hline $\mathrm{B}_{2} \mathrm{O}_{3}$ & 842 & 142 & 115 & 102 & 0.43 \\
\hline $\mathrm{NaCl}+\mathrm{CaCl}_{2}$ & 932 & 120.5 & NG & $\mathrm{NG}$ & 0.25 \\
\hline
\end{tabular}

NG - Not given. 
are basically in compliance with the selection criteria given earlier in this report.

The heat storage capabilities of some selected inorganic salt mixtures useful for solar energy storage in the high-temperature regime are compared in Fig. 5.6. Strictly on the basis of heat storage capability, sodium hydroxide $(\mathrm{NaOH})$ is superior to the others. Sodium hydroxide is abundantly available in large quantities and is relatively inexpensive. Several progress reports relating to the design and application of systems using $\mathrm{NaOH}$ have been issued.12-15 Because of the comparatively large amount of experience gained with $\mathrm{NaOH}$ systems to date, this system is proposed for initial selection as a means of storing solar energy at high temperatures.

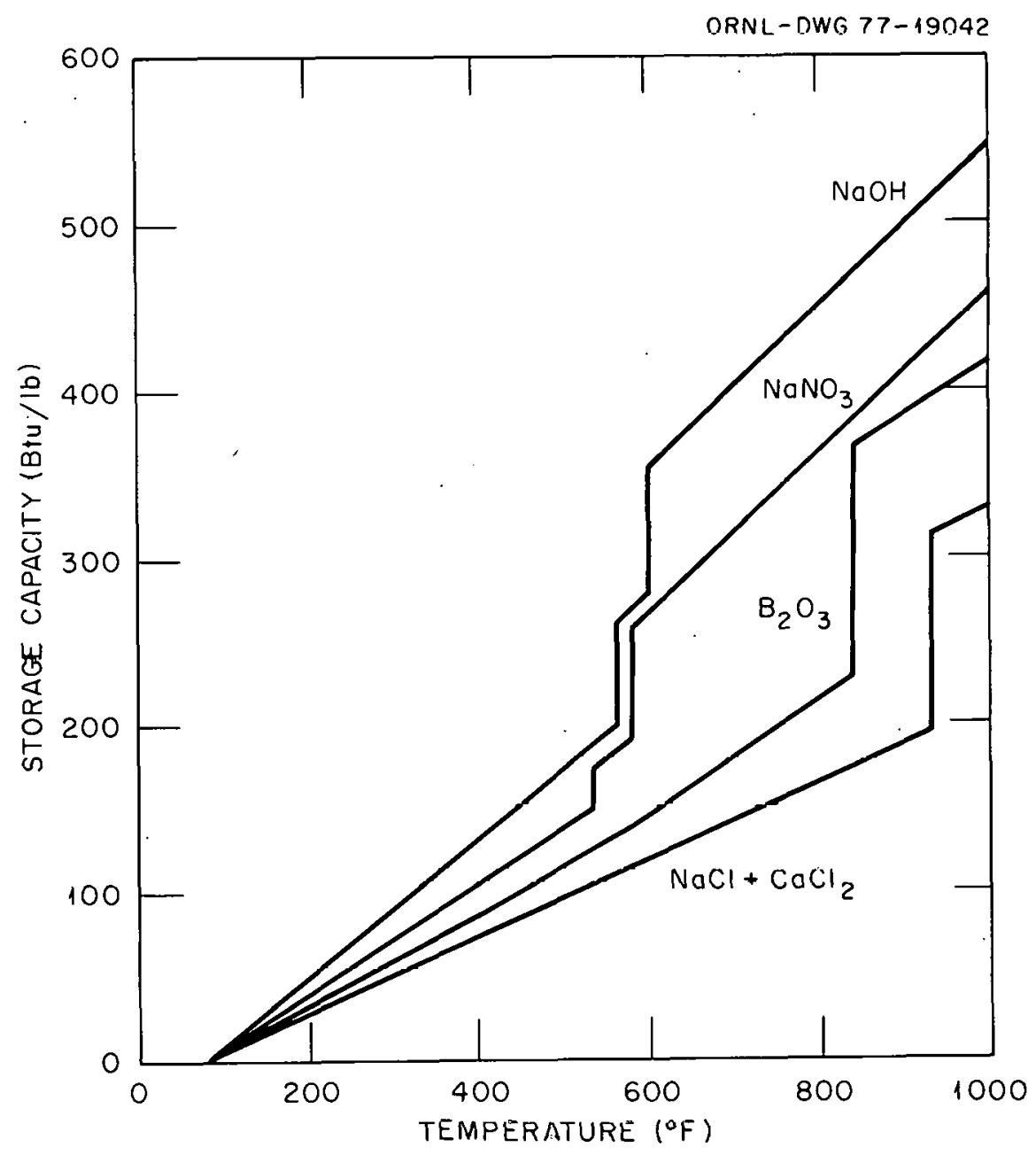

Fig. 5.6, Heat storage capability of selected inorganic salt mixtures in the high-temperature $\left(800\right.$ to $\left.1000^{\circ} \mathrm{F}\right)$ storage regime. 
The design of a space heater utilizing $\mathrm{NaOH}$ as the heat storage medium is shown in Fig. 5.7. This unit consisted of six modules containing $\mathrm{NaOH}$ capable of storing up to $400,000 \mathrm{Btu}(117 \mathrm{kWhr})$ at $950^{\circ} \mathrm{F}$. The modules were heated with electric resistance heaters and were cooled with air as the modules were discharged. The unit was later redesigned, using steel pipes filled with $\mathrm{NaOH}$ rather than the welded panels.

For the second-round investigation of solar energy storage in the high-temperature regime, one of the more exotic salt mixtures listed in Table 4.6 could be selected.

A combination of a Stirling engine with a remotely placed heat source has been investigated by the Philips Physical Research Laboratories. The Stirling engine is an externally heated engine in which thermal eneryy can be converted from an arbitrary origin, including solar heat, into mechanical energy with an efficiency of 35 to $40 \%$. One of the heat sources investigated consisted of a heat storage eystem from which heat was transported to the engine by means of a heat pipe. ${ }^{16}$

One of the heat storage media consisted of a mix of lithium and magnesium fluorides $\left(\mathrm{LiF} / \mathrm{MgF}_{2}\right)$. The $\mathrm{mix} \operatorname{TiF}(42.5 \%) / \mathrm{MgF}_{2}(57.5 \%)$ has a melting point of $1355^{\circ} \mathrm{F}$, a liquid-phase specific heat of $0.307 \mathrm{Btu}$ $1 b^{-1}{ }^{\circ} \mathrm{F}^{-1}$, and $a$ heat of fusion of $425 \mathrm{Btu} / 1 \mathrm{~b}$ (Table 4.6). While lithium is a relatively rare and expensive element, its content in the mix can be limited to about $10 \%$ by weight to minimize the cost.

The design of a laboratory model heat storage subsystem designed to contain high-temperature lithium salts is shown in Fig. 5.8 $8^{16}$ The storage material is contained in a Dewar vessel, which has several layers of metal foil in the evacuated space, resulting in a heat storage unit with a very low heat loss. Heat dissipation is achieved by introducing hydrogen gas to the evacuated interspace, causing a rise of pressure and thereby increasing the conduction from the otorage material. The hydrogen is produced by heating a small quantity of metal hydride (such as zirconium hydride) with an electric heater. When the electric heater is deactivated, the temperature of the hydride decreases, the hydrogen is recombined, and the pressure in the interspace decreases, thereby reducing conduction from the storage material.

\subsection{Thermal Energy Storage Efficiency}

The final selection of a thermal storage subsystem should be based on a detailed total system analysis, which includeu consideratiun of the performance characteristics of not only the storage subsystem but also the energy supply and conversion subsystems. However, there is a noticcable lack of experience in design, construction, and operation of large [0.5 MWhr(t) or greater] thermal energy storage systems. In addition, much of the material property data needed In design calculations is not available, and the various material stability and compatibility problems are not well-understood. 
ORNL-DWG 77-19917

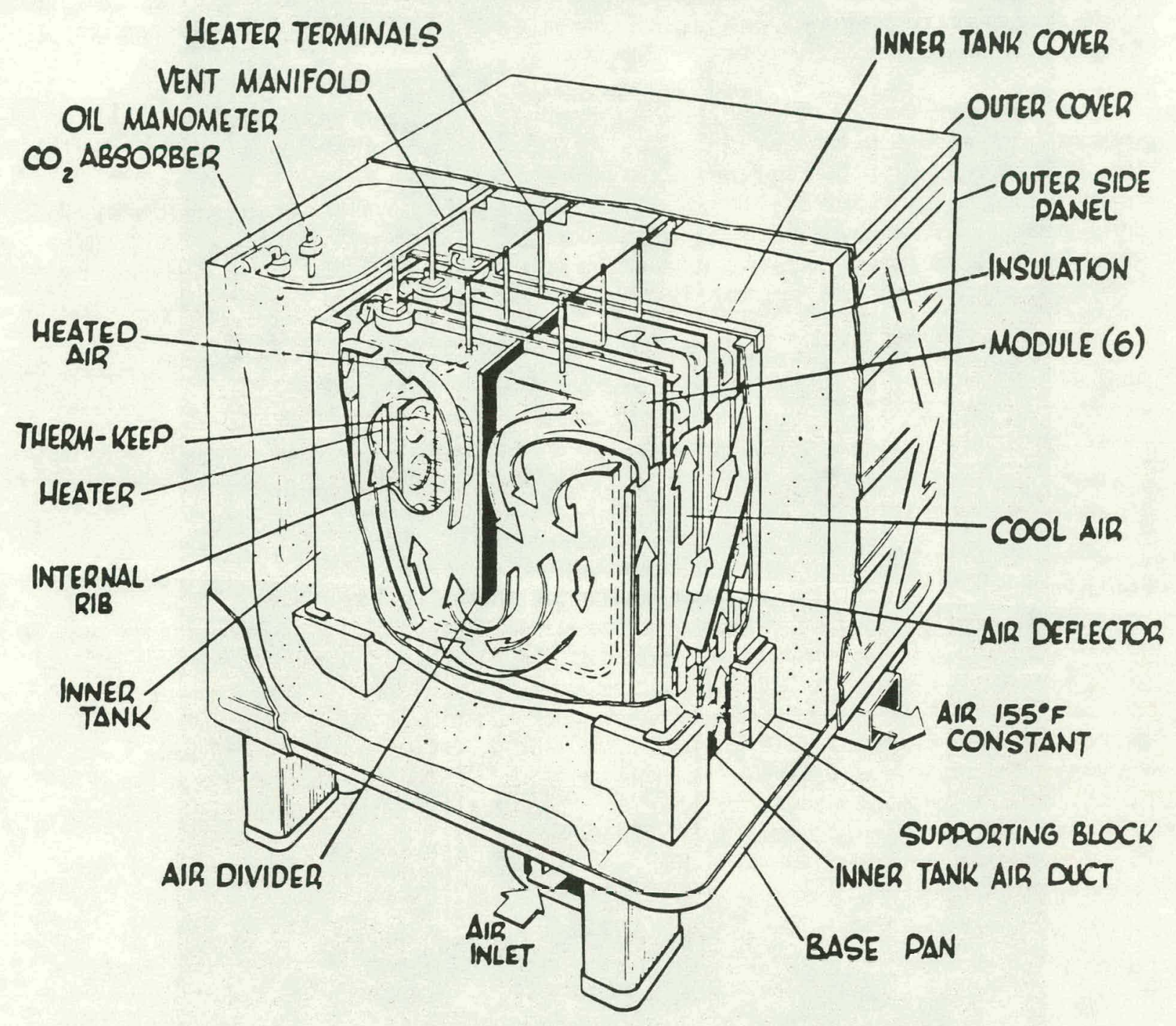

Fig. 5.7. Design of "therm-bank" space heater. Source: T. T. Bramlette et a1., Survey of high Temperature Thermal Energy Storage, SAND 75-8063, (Mar. 1976). 


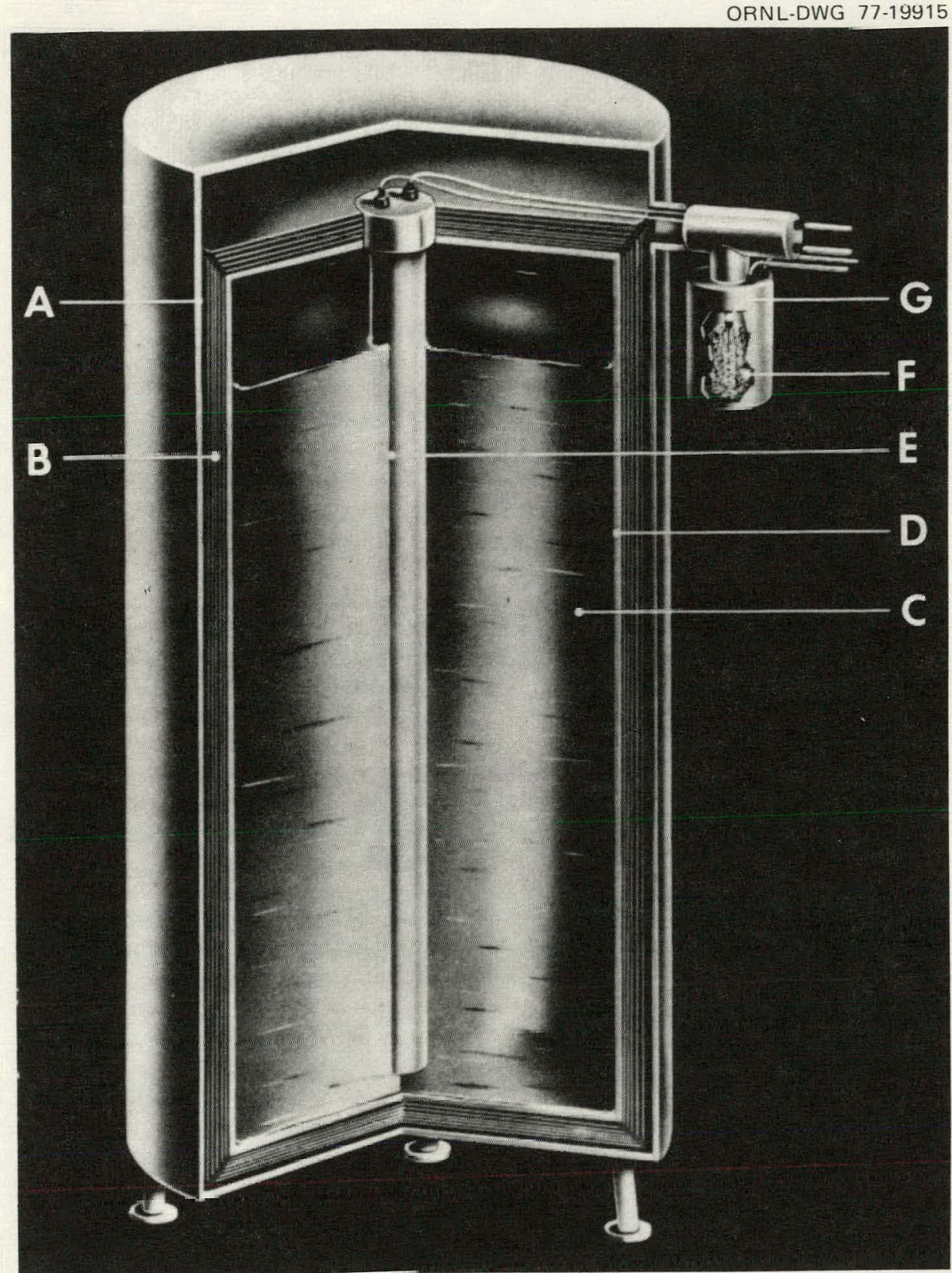

A Outer wall; B metal toıl; C liquid fluoride; $U$ ınner wall; E main heater; $F$ metal hydride; $G$ hydride heater

Fig. 5.8. Laboratory model of high-temperature heat storage unit. Source: "Heat Release Contro1," Engineering 214(4): 259 (April 1974). 
One of the important performance characteristics that needs to be considered is concerned with the efficiency at which the stored energy can be recovered for useful purposes. Several definitions applicable to water heating efficlencies are defined in the 1973 Systems Volume of the ASHRAE Handbook and Product Directory. ${ }^{7}$ By analogy, the efficiency of a thermal energy storage device may be defined as follows:

$$
\mathrm{E}_{\mathrm{e}}=\frac{\text { thermal energy out }}{\text { thermal energy in }} \text {. }
$$

This equation is essentially an expression of the energy losses resulting from processes related to the storage of energy, such as heat losses from the extension of the unit, and efficiencies of the internal heat transfer processes. Detailed thermodynamic analysis of representative heat storage systems must be accomplished to determine their performance characteristics and resultant heat storage efficiencies.

The usefulness of this concept of storage efficiency, when applied to Rankine-cycle or other heat power devices, is limited by the fact that it contains no information about the availability change that the energy may undergo due to the storage system. A storage system should be matched to the thermal characteristics of the supply and conversion systems in such a way that the availability loss from passing the energy through storage is minimized. In some systems, sensible heat storage will be most appropriate; while in others, latent heat or heat-of-reaction storage will be better suited. This process of characteristic matching and availability-loss minimization also may result in the use of a combined-type or hybrid storage system.

Since the availability describes the maximum amount of work obtainable from a quantity of thermal energy, the available energy storage efficiency compares the maximum work obtainable from the energy taken from storage with the maximum work obtainable from the energy originally supplied to storage. Specifically, the definition of available energy storage efficiency is the ratio of the availabilities of the energy discharged to the energy used to charge; that is,

$$
E_{a}=\frac{\text { availability of energy extracted }}{\text { availability of energy input }} \text {. }
$$

This particular expression for efficiency requires real performance characteristics for its evaluation. Thus the energy supply, storage, and conversion systems should be designed and analyzed in order to obtain the needed characteristics.

Insufficient data are available to list representative or expected efficiencies for intermediate- and high-temperature TES subsystems. However, some idea of the maximum efficiency that can be expected of low-temperature water TES subsystems can be inferred from data given in ref. 7. According to this reference, the maximum usable hot water from an unfired hot water storage tank is considered to be 60 to $80 \%$ of the 
storage capacity of the tank under normal draw conditions before dilution by colder water lowers the temperature below an acceptable level, assuming that the inlet and outlet connections have been properly designed. The usable hot water from an unfired tank in gallons per hour for peak draw can be calculated from the following equation:

$$
Q_{S}=\frac{0.7 S}{d} \text {, }
$$

where

$$
\begin{aligned}
& Q_{S}= \text { amount of water which may be drawn from the storage tank, } \\
& \text { gal/hr, } \\
& S=\text { capaclity of the vessel, gal, } \\
& \mathrm{d}=\text { duration of peak hot water draw, } \mathrm{hr} .
\end{aligned}
$$

'Ihe hot water storage tank should, therefore, be sized to compensate for any unusable stored energy. 
REFERENCES FOR SECTION 5

1. Harold Lorsch (ed.), Conservation and Better Utilization of Electric Power by Means of Thermal Energy Storage and Solar Heating Final Summary Report, NSF/RANN/SE/GI27976/TR/73/5, University of Pennsylvania National Center for Energy Management and Power (July 31, 1973).

2. Henry Kelly, "Outline Proposed by OTA for a Paper on Thermal Energy Storage," personal communication to H. W. Hoffman (Dec. 5, 1975).

3. C. L. Segaser, MIUS Technology Evaluation - Thermal Energy Storage Materials and Devices, ORNL/HUD/MIUS-23 (August 1975).

4. American Society of Mechanical Engineers, "Heating Boilers," ASME Boiler and Pressure Vessel Code, Section IV, New York (1968).

5. E. E. Pickering, "Residential Hot Water Solar Energy Storage," pp. 24-37 in Proceedings of the Workshop on Solar Energy Storage Subsystems for the Heating and Cooling of Buizdings, NSF-RANN75-041, American Society of Heating, Refrigerating, and Air Conditioning Engineers (April 1975).

6. E. S. Davis and Ralph Bartera, "Stratification in Solar Water Heater Storage Tanks," pp. 38-42 in Proceedings of the Workshop on Solar Energy Storage Subsystems for the Heating and Cooling of Buizdinge, NSF-RANN-75-041, American Society of Heating, Refrigerating, and Air Conditioning Engineers (April 1975).

7. American Society of Heating, Refrigerating, and Air Conditioning Engineers, "Hot and Cold Service Water," pp. 543-72 in ASHRAE Handbook and Product. Directory - 1973 Systems, chap. 37, New York, 1973.

8. G. A. Lane et a1., Solar Energy Subsystems Employing Isothermal. Heat Storage Mulerials, ERDA-117, Phase I. Terhnical Report (May 1975).

9. J. R. Fried, "Organic Fluids for High-Temperature Heat-Transfer Systems," Chemical Engineering 79(24): 96-104 (Oct. 30, 1972).

10. E. G. Bohlmann, Heat Transfer Salt for High-Temperature Steam Generation, ORNL/TM-3777, Oak Ridge National Laboratory (December 1972).

11. T. T. Bramlette et al., Survey of High Temperature Thermal Energy Storage, SAND 7j-8063, (Mar. 1976). 
12. Comstock and Wescott Engineering Company, "Study of Heat Storage Systems," unpublished report to EEI, 1958.

13. Comstock and Wescott, Inc., "First Step of Heat Storage Research Program Completed," in EEI BuZZ., June 1959.

14. Comstock and Wescott, Inc., "Second Phase Begins on Research Activity of Heat Storage Systems," pp. 307-9 in EEI BuZZ., September 1961.

15. Comstock and Wescott, Inc., "Promising Heat Storage Material

Found through Research," pp. 49-50 in EEI Bull., February 1962.

16. "Heat Release Contro1," Engineering 214(4) (April 1974). 


\section{SOLAR THERMAL ENERGY STORAGE COST CONSIDERATIONS}

The major new items needed for economical solar energy conversion are an efficient low-cost collector system and a convenient, low-cost, efficient method of storing solar energy as heat. In order to obtain capital cost comparisons of the various thermal energy storage (TES) concepts available for solar energy conversion systems, the cost per kilowatt-hour of thermal energy stored should be estimated for representative storage subsystems over the full range of storage sizes required. The capital costs are divided into costs of major components, including (1) the cost of the TES material, (2) the cost of the TES material containment unit, (3) the cost of thermal insulation, and (4) the installation and transportation costs. It is important to note that these considerations include only the capital costs. The final cost effectiveness of a particular concept should be determined by a life-cycle cost analysis, and such an analysis is beyond the scope of this study.

\subsection{TES Material Costs}

The cost and heat storage capability in the desired temperature range of the candidate TES material are important criteria that must be considered in the selection of an appropriate solar energy storage subsystem. One source of current market prices for chemicals that are considered for use as thermal energy storage media is the Chemical Marketing Reporter. 1 Cost quotations in this reference are listed weekly for technical-grade materials. However, the bulk materials as received may not be of sufficient purity for direct use for a thermal storage unit. Since purification techniques are not adequately defined nor are their prices estimated at this time, the costs obtained from rof. 1 will represent minimum material prices only. The lowest-cost materials will probably consist of bulk quantity chemicals based on compounds of the common elements - sodium, potassium, calcium, magnesium, aluminum, and 1ron. The types of low-cost salts will probably be restrictcd to chlorides, sulfates, nitrates, phosphates, or carbonates.

Quoted market prices ${ }^{l}$ of the various constituents of inorganic salt hydrates and eutectics proposed for solar thermal energy storage subsystems are listed in Table 6.1. These prices reflect the list prices prevailing during the early months of 1976 for large lots f.o.b. New York. The differences between high and low prices may be accounted for by differences in quantity, quality, or locality, according to ref. 1. The quotations given in ref. 1 do not necessarily reflect prices at which traneactions actually may have occurred.

Some of these salts can be combined with water to form hydrated compounds, many of which have been proposed for use as 'lES media, particularly in the low-temperature regime (Table 4.2). Others can be used in various combinations to form eutectics for higher-temperature TES applications (Table 4.6). 
Table 6.1. Early 1976 market prices of constituents for proposed inorganic salt hydrate and eutectic thermal energy storage media

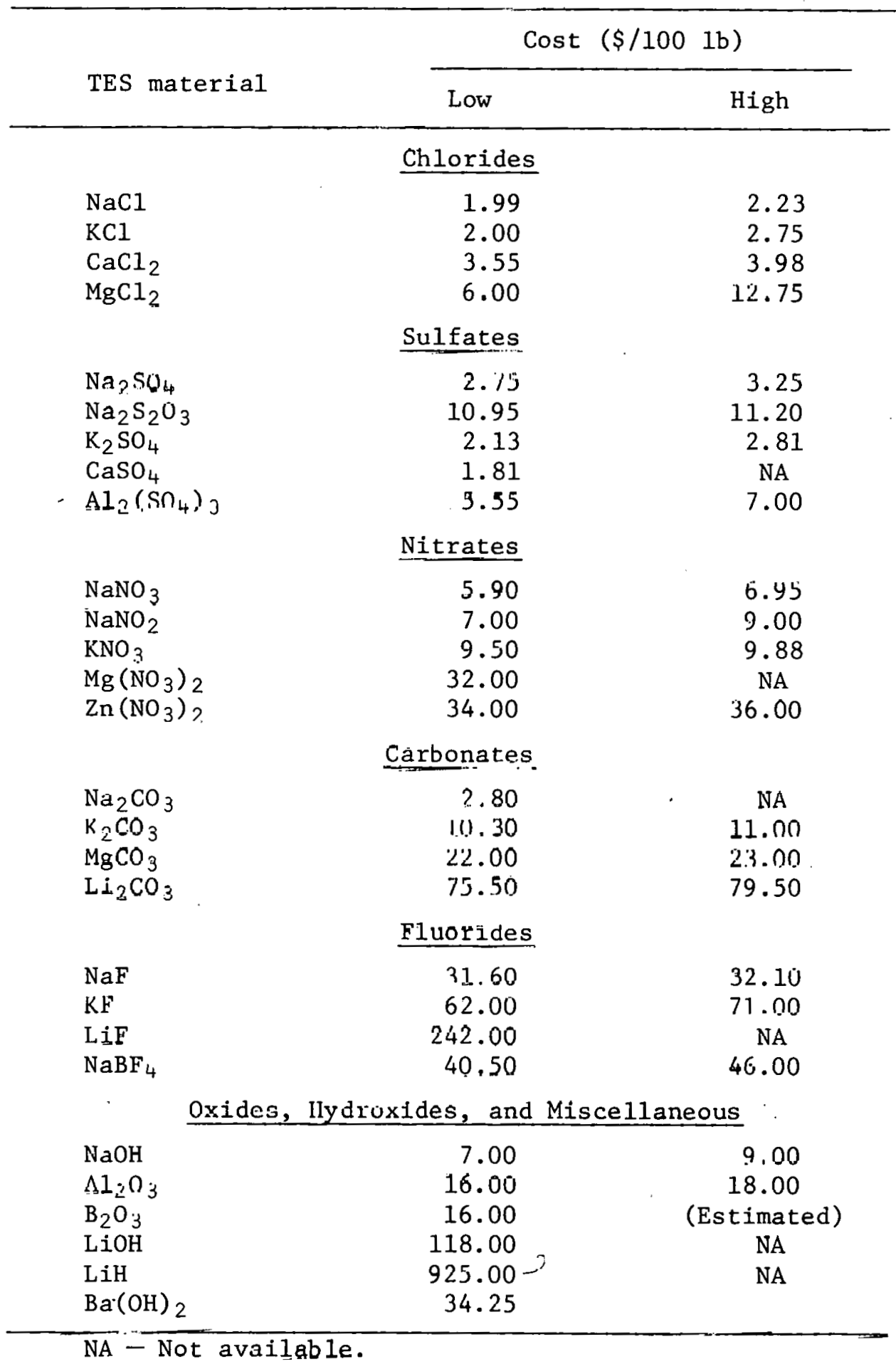




\subsection{TES Containment Unit Costs}

The cost of the heat-exchanger-containment unit is one of the key factors that determines the practicality of thermal energy storage for solar power applications. Therefore, the final cost comparisons should be based on the complete "in-place" installation, rather than on the cost of the TES material only. Several criteria must be considered in the design and construction of suitable containment devices for thermal energy storage.

1. The containment vessel should be of high integrity to prevent loss of the TES material and prevent evaporation of the water of crystallization if the TES material is a salt hydrate.

2. The containers must be resistant to corrosion by the TES material in either the solid or liquid phase.

3. The container material must be able to withstand repeated phasechange cycling without compromise.

4. Adequate heat exchange surfaces must be incorporated to permit transfer of stored heat to and from the storage material. The heat transfer surface may consist of tubular, short-cylindrical, flat-plate, or other geometries.

5. The containment should be of an inexpensive and readily fabricable material.

\subsubsection{Latent heat TES unit costs}

Thermal energy storage devices suitable for space heating through solar energy and using latent heat or sensible heat storage materials were analyzed by Lorsch ${ }^{2}$ and associates at the University of Pennsylvania under National Science Foundation RANN Grant GI-27976. This study included the costs of heat-exchanger-containment devices for latent heat storage materials. The TES designs considered are shown in Figs. 6.1 through 6.3. The estimated costs of these units for a range of TES material costs are given in Fig. 6.4 .

To achieve adequate heat transfer area and storage capability, the TES material was assumed to be packaged in container units with a high ratio of area to volume. These units are then stacked in a module, as shown in Fig. 6.1, and the whole placed inside of a steel or other containment in a cubic array. The unit is then filled with suitable heat transfer media to function as a complete TES-heat-exchanger package. This configuration is only one of many possible types, but it is the one chosen by the University of Pennsylvania group for analysis.

The containment unit materials considered in the designs shown in Figs. 6.1 through 6.3 included plastic, aluminum, and mild steel. The 


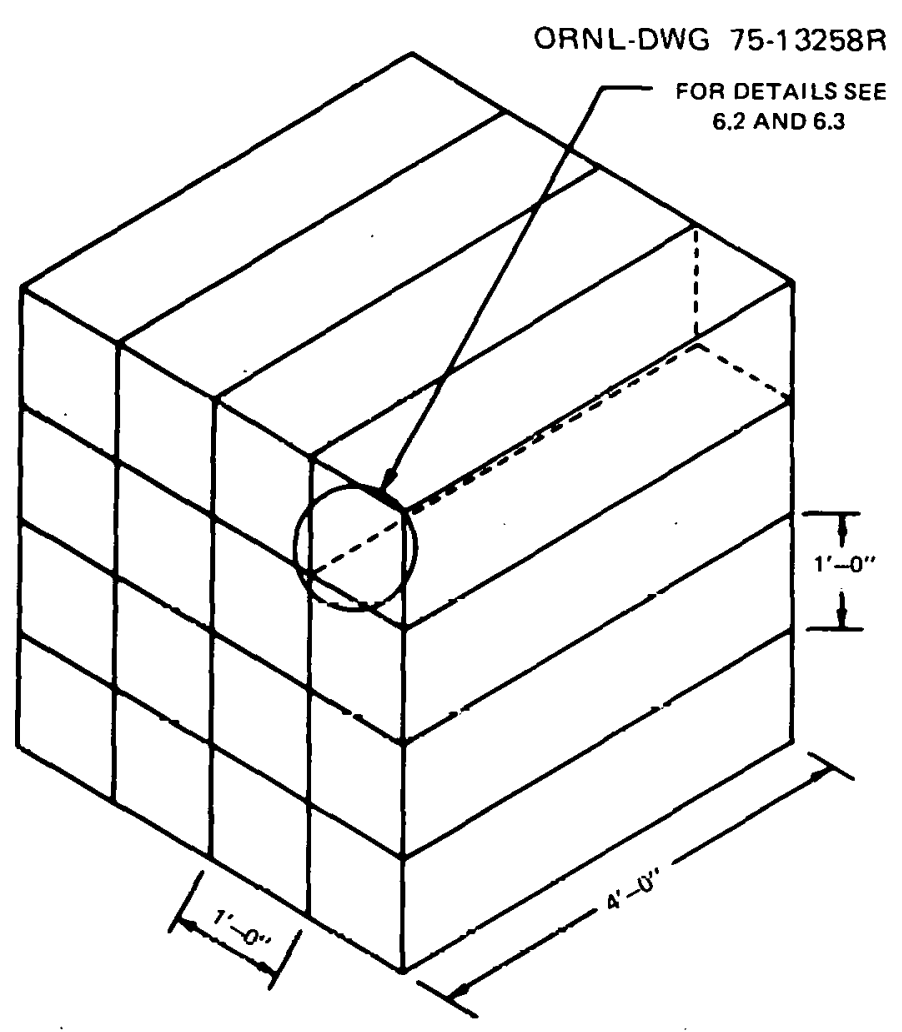

Fig. 6.1. TES-heat exchanger unit (500,000 Btu), using sodium thiosulfate pentahydrate (headers at left front and right rear not shown). Source: By permission from H. G. Lorsch, "Thermal Energy Storage Devices Suitable for Solar Heating," Paper 749083 in Proc. 9th Intersoc. Fnergy Convers. Eng. C'onf., The American Society of Mechanical Engineers, New York (August 1974), Fig. 2., p. 574.

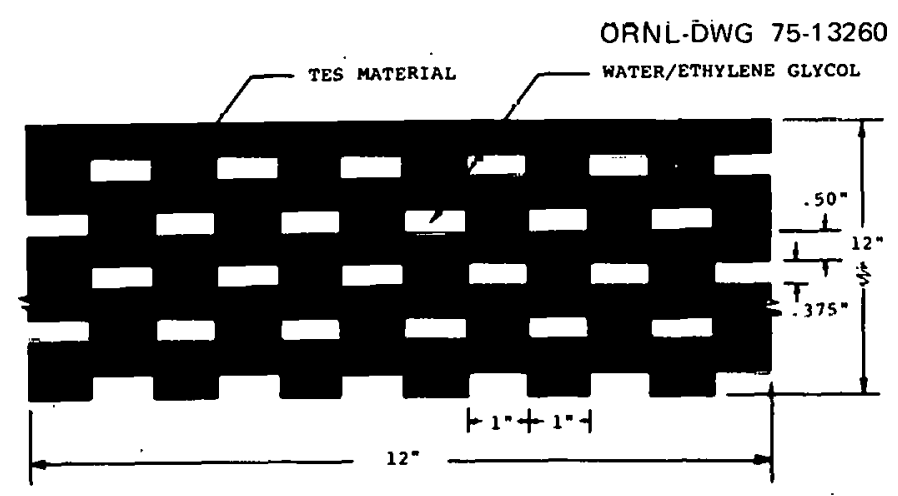

Fig. 6.2. TES module $\mathrm{fr}$ sodium thiosulfate pentahydrate. Source: By permission from H. G. Lorsch, "Thermal Energy Storage Devices Suitable for Solar Heating," Paper 749083 in Proc. 9th Intersoc. Energy Convers. Eng. Conf., The American Society of Mechanical Engineers, New York (August 1974), Fig. 3, p. 574. 


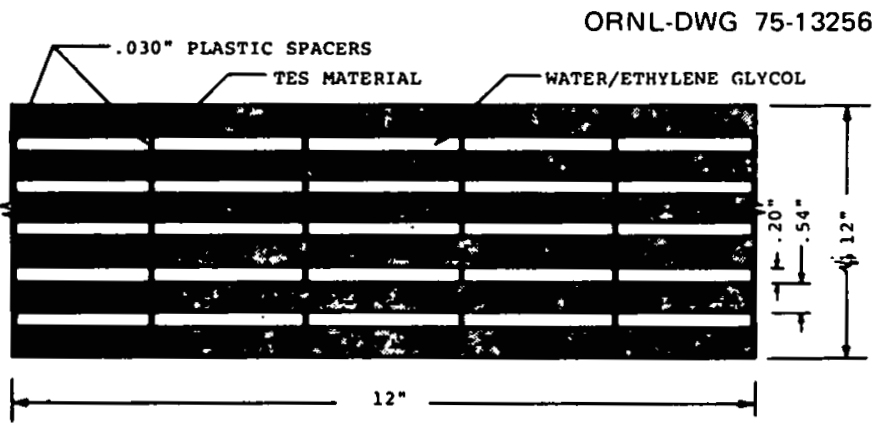

Fig. 6.3. TES module for P116 paraffin wax. Source: By permission from H. G. Lorsch, "Thermal Energy Storage Devices Suitable for Solar Heating," Paper 749083 in Proc. 9th Intersoc. Energy Convers. Eng. Conf., The American Society of Mechanical Engineers, New York (August 1974), Fig. 4, p. 575 .

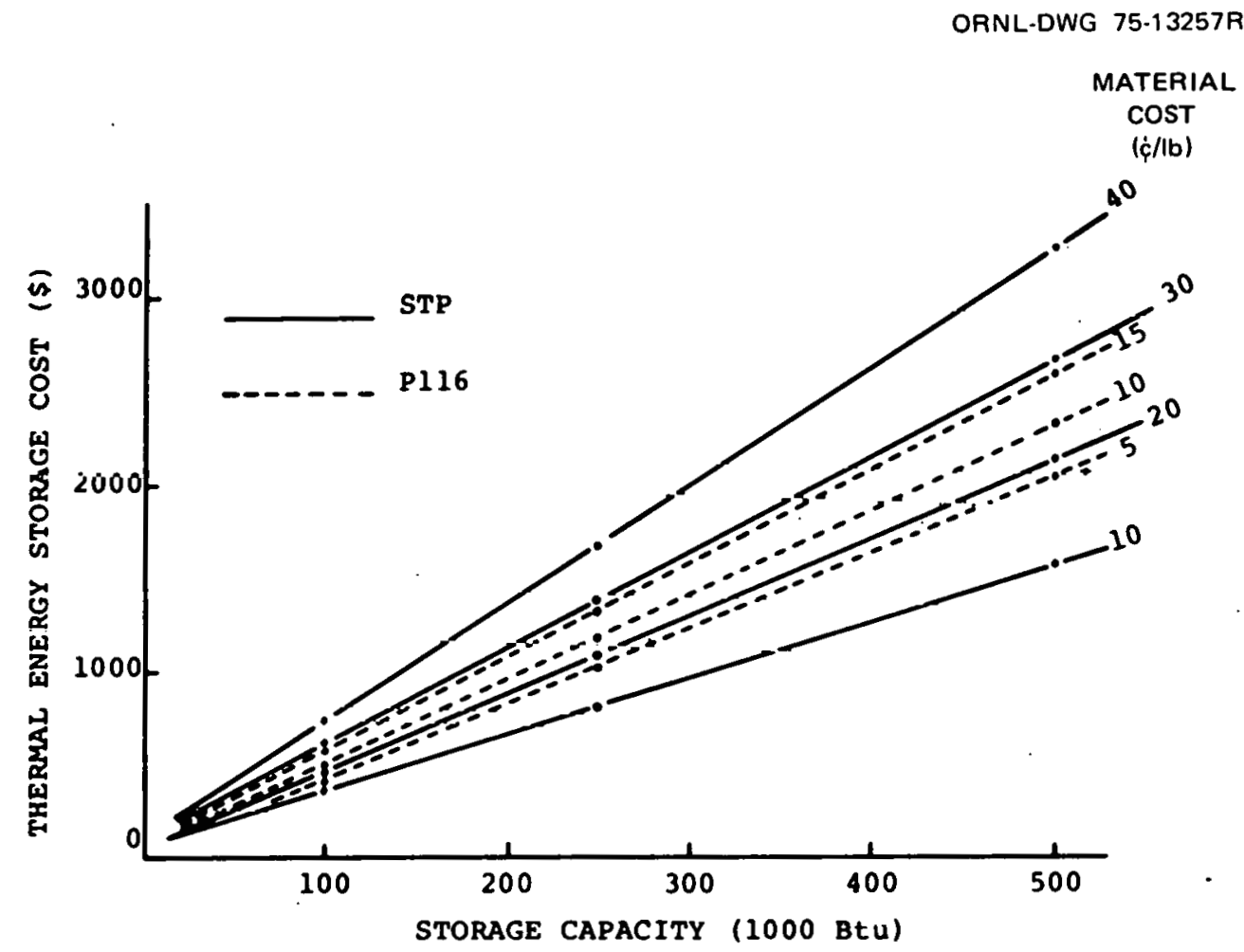

Fig. 6.4. Cost of latent heat storage vs storage capacity (for two different materials and a range of material costs). Source: By permission from H. G. Lorsch, "Thermal Energy Storage Devices Suitable for Solar Heating," Paper 749083 in Proc. 9th Intersoc. Energy Convers. Eng. Conf., The American Society of Mechanical Engineers, New York (August 1974), Fig. 6, p. 576. 
most reliable cost information available at the time was used. The TES costs shown in Fig. 6.4 include manufacture, shipping, and installation. The least expensive combination of materials was used, considering compatibility requirements between container materials and heat storage materials.

Two phase-change materials, with characteristics as follows, were selected:

TES material

\begin{tabular}{ccc} 
Characteristic & $\begin{array}{c}\text { Sodium thiosulfate } \\
\text { pentahydrate }\end{array}$ & $\begin{array}{c}\text { Sunoco P1l6 } \\
\text { paraffin wax }\end{array}$ \\
\hline Heat of fusion, Btu/1b \\
Rtu/ft
\end{tabular}

Sodium thiosulfate pentahydrate (STP) has been found to have certain properties that may detract from its desirability as a TES material. ${ }^{2}$ However, the results of the analyses in ref. 2 are considered to be valid for any other phase-change TES material having simllar thermal properties.

Figure 6.2 shows one design of a tray unit for the organic TES materlal (Sunoco P116 paraffin wax). Because of the lowcr value of heat cundulivicy, the heat transfer through the wax is the limiting factor; therefore, ribbed containers were not required.

In both unit designs, $a$ onc-to vile 'wlxicure of water and ethylene glycol is used as the liquid heat transfer medium from solar collector to storage. Bnth complcte modules are designed to store 500,000 Btu of heat. The module containing the organic wax (Sunnrn f116) occuples morc than twu lines the volume of the STF. Although the weights of the TES material are about the same, the total weight of the complete unit for the wax is considerably greater because of the larger containment volume.

\subsubsection{Sensible heat TES unit costs}

Because of its unique properties, water (or a mixture of water and ethylene g1ycol) has been and will continue to be widely used as a sensible heat storage medium. A major advantage of thermal energy storage in water is due to the fact that usually no heat exchanger surface in the containment vessel is required, since the thermal conveyance fluid can 
be identical. A variety of storage tanks for water are readily available, relatively inexpensive, and reliable.

The quantity of water in a sensible heat storage device is a negligible cost item. However, the cost of additives to inhibit corrosion or prevent freezing can represent a significant expense. If the water is to be provided from an existing utility system, there will be a charge for the amount of water provided. The cost of supplying water from a surface or ground source is largely a matter of pumping costs. Two MIUS technology evaluation reports include cost-estimating data for a variety of water storage tanks. 3,4

The Working Group on Hot Water Storage Systems ${ }^{5}$ felt that, in comparison with the other alternatives currently available, water is probably the best and least expensive mode of thermal energy storage in the low-temperature regime.

\subsection{Estimated Costs of Solar Energy Storage Devices}

Estimated costs per $\mathrm{kWhr}(1 \mathrm{kWhr}=3413 \mathrm{Btu})$ of latent heat TES devices over the specified range of storage capacities up to $36 \times 10^{5} \mathrm{kWhr}$ are shown in Fig. 6.5. These costs were estimated from data given in Fig. 6.4, using a procedure described in ref. 6. This procedure is based on the assumption that cost data can be adequately represented by a straight-line relationship between costs and capacity factor on loglog coordinates over a reasonable range of capacities. In addition, the method described in ref. 6 includes an escalation factor to account for time. The following expression is given to estimate the cost of a specific item of equipment from the known cost of a similar but different capacity item:

$$
C_{D}=C_{K}\left(\frac{H_{D}}{H_{K}}\right)^{N} \frac{I_{D}}{I_{K}} \text {, }
$$

where

$$
\begin{aligned}
& C_{D}=\text { desired cost, } \$, \\
& C_{K}=\text { known cost, } \$ \\
& H_{D}=\text { desired capacity, kWhr, } \\
& H_{K}=\text { known capacity, kWhr, } \\
& I_{D}=\text { present cost index, } \\
& I_{K}=\text { previous cost index, } \\
& \mathrm{N}=\text { a constant depending on specific type of equipment. }
\end{aligned}
$$




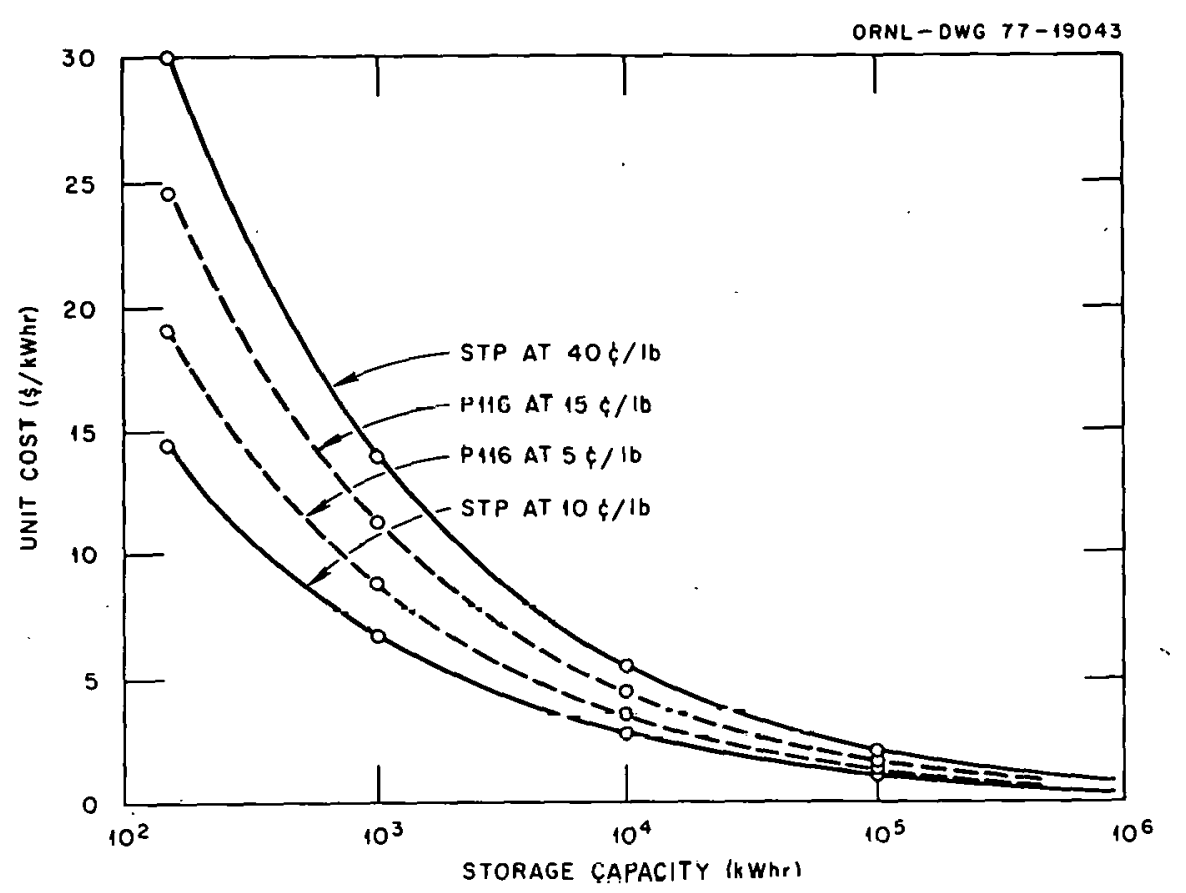

Fig. 6.5. Est1mated costs per kWhr of storage capacity for solar thermal energy storage devices.

The constant $\mathrm{N}$ is assumed to be approximately 0.6 for estination purposes. The "Marshall and Swift (M\&S) Equipment Cost Index" is used to account for escalated cost due to time.

Figure 6.5 Indicates that the costs of TES devices can range from about $\$ 30$ per $\mathrm{kWhr}$ for a unit to store $147 \mathrm{kWhr}(500,00 \mathrm{n} \mathrm{R}+\mathrm{u})$ down to about $\$ 1.50$ por lcWhr tu slure $3 \dot{b} \times 10^{\mathrm{J}} \mathrm{kWhr}\left(1.229 \times 10^{10} \mathrm{Btu}\right)$ when employing STP as the TES material at $\$ 0.40 / 1 \mathrm{~b}$. However, if the cost of this material is signtficantly less $(n, \$ 0.10 / 1 b)$, the cost of the storage device would range frnm about $\$ 15$ pei k.Whr to about $\$ 1.00$ per kWhr. The costs of the units using the organic material (Sunoco P116 paraffin wax) are intermediate within these extremes.

\subsection{Thermal Insilation Costs}

Numerous documents ${ }^{8-12}$ describing procedures for determining the optimum thickness of insulation for process vessels are available. An assessment of the status of current thermal insulation technology is given in ref. 12, Tahles I, II, III, and IV of ref. 13 give material costs and installation labor to permit estimation of the costs required to insulate process vessels. Tables I and II of ref. 13 give costs per square foot for hot and cold insulation blocks of varying thicknesses. 
Direct field labor man-hours for various vessel insulation operations are shown in Table III of ref. 13. Table IV of ref. 13 is an attempt at combining two "judgement" factors to adjust "ideal" conditions to actual job conditions for arriving at a more realistic cost estimate for an insulating job.

Al1 the cost data presented in ref. 13 were developed assuming good design and installation practices. In general, these practices include single insulation below $800^{\circ} \mathrm{F}$ and multiple layer for 800 to $1200^{\circ} \mathrm{F}$. The insulation is assumed to be always applied in sectional or segmented form, using the "broken joint" technique, and all joints are sealed with asbestos cement. All costs given in ref. 13 are based on November 1962 prices; therefore, an escalation factor 6,7 must be applied to arrive at current costs. 


\section{REFERENCES FOR SECTION 6}

1. Chemical Marketing Reporter, Schnell Publishing Co., New York (Mar. 1, 1976).

2. H. G. Lorsch, "Thermal Energy Storage Devices Suitable for Solar Heating," Paper 749083 in Proc. 9th Intersoc. Energy Convers. Eng. Conf., The American Society of Mechanical Engineers, New York (August 1974).

3. C. L. Segaser, MIUS Technology Evaluation - Thermal Energy Storage Materials and Devices, ORNL/HUD/MIUS-23 (August 1975).

4. C. L. Segaser and W. R. Mixon, MIUS Systems Analysis, the Effects of Thermal Energy Storage and Solid Waste Incineration Optionss on MIUS. Cost and Fuez Cunsumption, ORINL/HUD/Misus-26 (July 19\%).

5. G. C. Szego, Chairman, "Hot Water Storage Systems Group Report," p. 165 in Proceedings of the Workshop on Solar Energy Storage Subsysteme for the Heating and Cooling of Buizdings, NSF-RANN-75-041, American Society of Heating, Refrigerating, and Air Conditioning Engineers (April 1975).

6. G. M. Hoerner, Jr., "Nomograph Updates Process Equipment Costs," Chemical Engineering 83(11): 141-43 (May 24, 1976).

7. "M\&S Equipment Cost Index, Economic Indicators," Chemical Engineering 83(11): 7 (May 24, 1976).

8. D. J. Dickson, "Thermal Insulation for Energy Storage," Paper 6495P, Proceedings of the Institution of Electrical Fngineers, Powor, vol. 118 (June 16, 1971).

9. William $0^{\prime K e e f e, ~ " T h e r m a l ~ I n s u l a t i o n . " ~ P o l u e x, ~ 118(8): ~ 21-44 ~(A u g u e t ~}$ 1974).

10. York Research Corporation, "How to Determine Economic Thickness of Insulation," ECON-1, Thermal Insulation Manufacturers Association, 1973.

11. W. C. Turner, "Criteria for Installing Insulation Systems in Petrochemical Plants," Chem. Eng. Prog. 70(8): 41-59 (August 1974).

12. R. G. Donnelly et al., Industrial Thermal Insulation, an Assessment, ORNL/TM-5283, Oak Ridge Nationa1 Laboratory (March 1976).

13. T. N. Dinning, "Guide to Insulation Costs for Vesse1s," pp. 155-56 In Modern Cost-Engineering Techniques, Herbert Popper et al. (eds.), McGraw-Hi11, New York, 1970. 
ORNL/TM-5758

INTERNAL DISTRIBUTION

1. T. D. Anderson

2. S. E. Beal1

3. H. I. Bowers

4. R. S. Car1smith

5. C. V. Chester

6. J. E. Christian

7-11. D. M. Eissenberg

12. W. Fulkerson

13. H. W. Hoffman

14. R. S. Holcomb

15. S. I. Kaplan

16-25. R. J. Ked1

26. J. O. KoIb

27. C. G. Lawson

28. R. E. MacPherson
29. J. T. Meador

30. J. W. Michel

31-35. W. R. Mixon

36. J. C. Moyers

37. G. D. Pine

38. G. Samuels

39. C. L. Segaser

40. M. J. Skinner

41. I. Spiewak

42. H. E. Tramme11

43-45. Central Research Library

46-48. Laboratory Records

49. Laboratory Records, ORNL-RC

50. Document Reference Section

51. ORNL Patent office

EXTERNAL DISTRIBUTION

52. T. J. Marciniak, Argonne National Laboratory, Energy Environmental Systems Division, 9700 Cass Avenue, Argonne, IL 60439

53. J. Oriando, Mathematica, Inc., Suite 2970, 475 L'enfant Plaza West, Washington, DC 20024

54. C. W. Phillips, National Bureau of Standards, Room A146, Building 225, Washington, DC 20234

55. J. H. Rothenberg, HUD-MIUS Program Manager, Department of Housing and Urban Development, 451 th Street SW, Room 8158, Washington, DC 20410

56. Research and Technical Support Division, Department of Energy, Oak Ridge Operations, Oak Ridge, TN 37830

57-83. Technical Information Center, DOE, P.0. Box 62, Oak Ridge, TN 37830 